HTGR Fuel Recycle Development Program (189a OHO45)

Studies and Analyses - Task 100

Studies and Evaluations (189a 01303)

Hanford Engineering Development Laboratory (PO Y9U-M44-671)

\title{
NUCLEAR FUEL FABRICATION AND REFABRICATION COST ESTIMATION METHODOLOGY
}
R. R. Judkins
A. R. Olsen

Date Published - November 1979

NOTICE This document contains information of a preliminary nature. It is subject to revision or correction and therefore does not represent a final report.

OAK RIDGE NATIONAL LABORATORY

Oak Ridge. Tennessee 37830 operated by

UNION CARBIDE CORPORATION

for the

DEPARTMENT OF ENERGY 


\section{DISCLAIMER}

This report was prepared as an account of work sponsored by an agency of the United States Government. Neither the United States Government nor any agency Thereof, nor any of their employees, makes any warranty, express or implied, or assumes any legal liability or responsibility for the accuracy, completeness, or usefulness of any information, apparatus, product, or process disclosed, or represents that its use would not infringe privately owned rights. Reference herein to any specific commercial product, process, or service by trade name, trademark, manufacturer, or otherwise does not necessarily constitute or imply its endorsement, recommendation, or favoring by the United States Government or any agency thereof. The views and opinions of authors expressed herein do not necessarily state or reflect those of the United States Government or any agency thereof. 


\section{DISCLAIMER}

Portions of this document may be illegible in electronic image products. Images are produced from the best available original document. 



\section{CONTENTS}

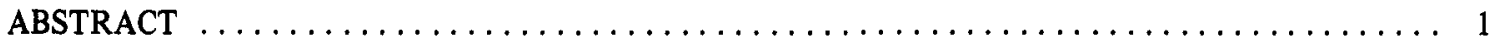

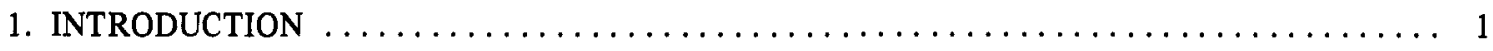

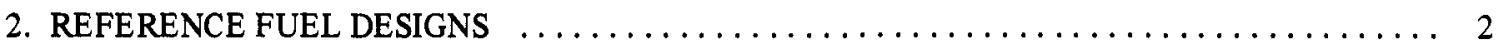

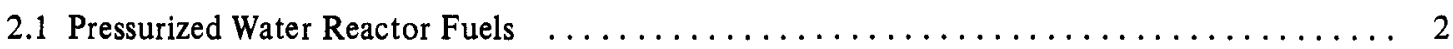

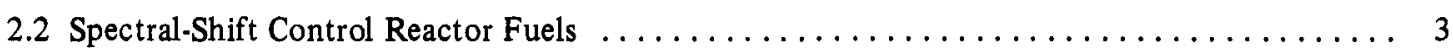

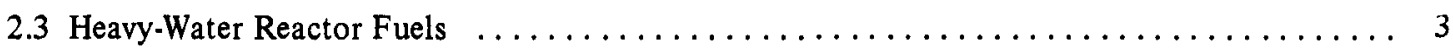

2.4 Liquid-Metal Cooled Fast Breeder Reactor Fuels $\ldots \ldots \ldots \ldots \ldots \ldots \ldots \ldots \ldots \ldots \ldots \ldots \ldots$

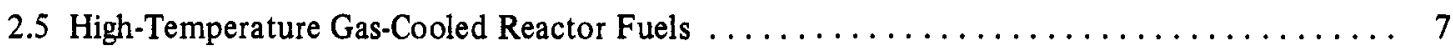

3. FABRICATION AND REFABRICATION PROCESSES $\quad \ldots \ldots \ldots \ldots \ldots \ldots \ldots \ldots \ldots \ldots \ldots$

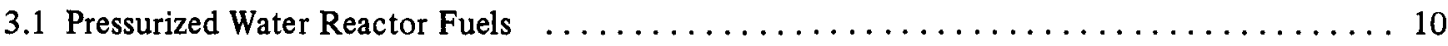

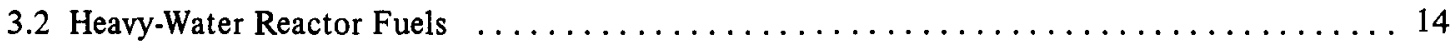

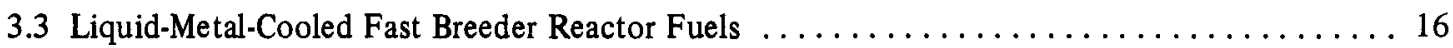

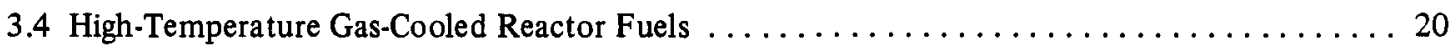

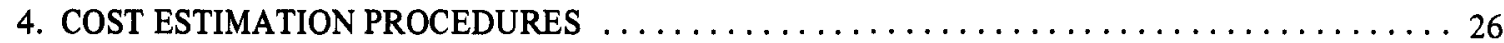

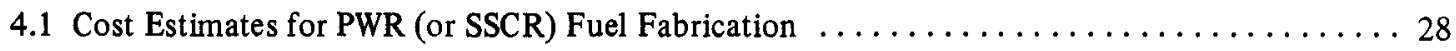

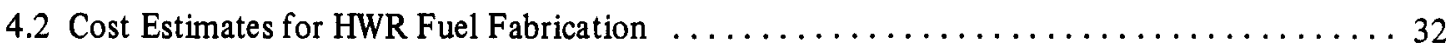

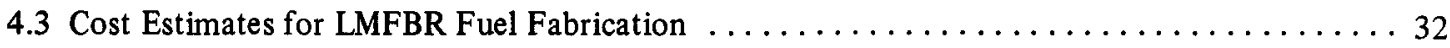

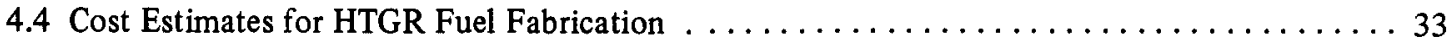

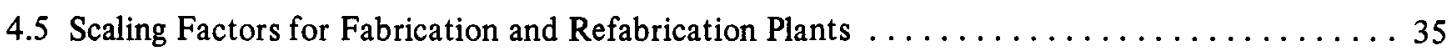

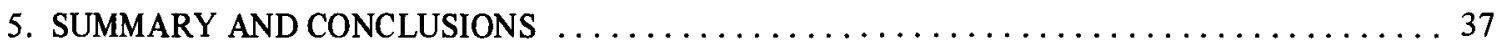

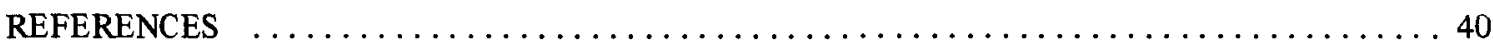

Appendix A. SUMMARY OF CAPITAL, OPERATING, AND MATERIALS COSTS ESTIMATES

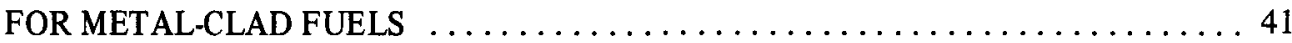

Appendix B. SUMMARY OF CAPITAL, OPERATING, AND MATERIALS COSTS ESTIMATES

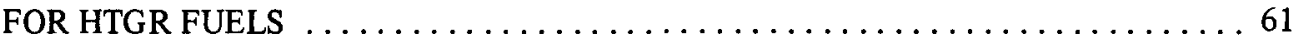




\title{
NUCLEAR FUEL FABRICATION AND REFABRICATION COST ESTIMATION METHODOLOGY
}

\author{
R. R. Judkins A. R. Olsen
}

\begin{abstract}
The costs for construction and operation of nuclear fuel fabrication facilities for several reactor types and fuels were estimated, and the unit costs (prices) of the fuels were determined from these estimates. The techniques used in estimating the costs of building and operating these nuclear fuel fabrication facilities are described in this report.

Basically, the estimation techniques involve detailed comparisons of alternative and reference fuel fabrication plants. Increases or decreases in requirements for fabricating the alternative fuels are identified and assessed for their impact on the capital and operating costs.

The impact on costs due to facility size or capacity was also assessed, and scaling factors for the various capital and operating cost categories are presented. The method and rationale by which these scaling factors were obtained are also discussed.

By use of the techniques described herein, consistent cost information for a wide variety of fuel types can be obtained in a relatively short period of time. In this study, estimates for 52 fuel fabrication plants were obtained in approximately two months. These cost estimates were extensively reviewed by experts in the fabrication of the various fuels, and, in the opinion of the reviewers, the estimates were very consistent and sufficiently accurate for use in overall cycle assessments.
\end{abstract}

\section{INTRODUCTION}

One of the purposes of the Alternative Fuel Cycle Evaluation Program (AFCEP) is to identify nuclear systems and nuclear fuel cycles that have high proliferation resistance and at the same time have commercial potential.

An important factor with respect to the commercial potential of nuclear fuel cycles is the cost associated with the fabrication of a candidate fresh or recycle fuel.* In this study, 21 reactor and fuel-cycle combinations were identified for the purpose of determining fabrication costs. There were 52 variations of fuels and fuel types, and these included fuels for light-water reactors (specifically, pressurized water reactors - PWR), spectral-shift control reactors (SSCR), heavy-water reactors (HWR) of the CANDU type, liquid-metal cooled fast breeder reactors (LMFBR), and high-temperature gas-cooled reactors (HTGR).

To facilitate the preparation of this very large number of estimates, a methodology was developed that related all metal-clad fuels to a reference PWR case previously reported. ${ }^{1}$ Fabrication costs for HTGR fuels were estimated by scaling costs based on a conceptual design performed for a Target Recycle Plant (TRP) for HTGR fuels. ${ }^{2}$ The methods used are similar to those in an earlier nuclear fuel fabrication cost study. ${ }^{3}$ The current study provides considerably more detail and improves the consistency and accuracy of the estimates while retaining the basic techniques for comparison of reference and alternative fuel fabrication facilities.

The purpose of this paper is to describe the techniques used in the estimation of capital, operating, and material costs associated with the fabrication of nuclear fuels. Unit costs, that is, prices, of the fuels were determined by an economic analysis of the basic cost estimates, and these unit costs were previously reported. ${ }^{4}$

\footnotetext{
*In this paper, fabrication of recycle fuels is referred to as refabrication.
} 
The ultimate test of economic studies such as that described here is, of course, the agreement of the estimates with the actual costs of constructing and operating the facilities. At best, it will be many years before some of the fuels considered in this report are fabricated. Regulatory and other changes that were not anticipated in this study will probably be in effect at that time, and the actual costs may be quite different from those estimated here. However, it is our belief that for the purpose of determining relative costs of a large number of fuels, the methods described herein are quite good and represent a very useful tool for helping to establish the commercial potential of a particular nuclear fuel.

Details of the methodology developed in this study are presented in the following sections. We have also included some details of the fuel designs that were considered and details of the fuel fabrication processes. These details are necessary because of the dependence of costs on fuel element designs and method of fabrication.

\section{REFERENCE FUEL DESIGNS}

\subsection{Pressurized Water Reactor Fuels}

Two fuel assembly designs were considered for the pressurized water reactor fuels. One of these was a Westinghouse Electric Corporation 17- by 17-rod-array fuel assembly, ${ }^{5}$ and the other was a Combustion Engineering 16- by 16-rod-array fuel assembly. ${ }^{6}$

Although there are similarities in design of these fuel assemblies, important differences do exist. Design descriptions of the two fuel assemblies are presented in the following paragraphs.

In the Westinghouse design, 264 fuel rods, 24 guide thimble tubes, and 1 instrumentation tube are arranged within a supporting structure to form a fuel assembly. Figure 1 shows a full-length view of this fuel assembly, and Table 1 provides a summary of the components of the assembly. The structural integrity of the fuel assembly is maintained by a skeleton that consists of 2 end fittings or nozzles, 8 grids, the 24 guide thimble tubes, and the instrument tube. The guide thimble tubes are joined to the grids by swaging the tubes to sleeves within the grid. The bottom nozzle is at tached to the guide thimble tubes with
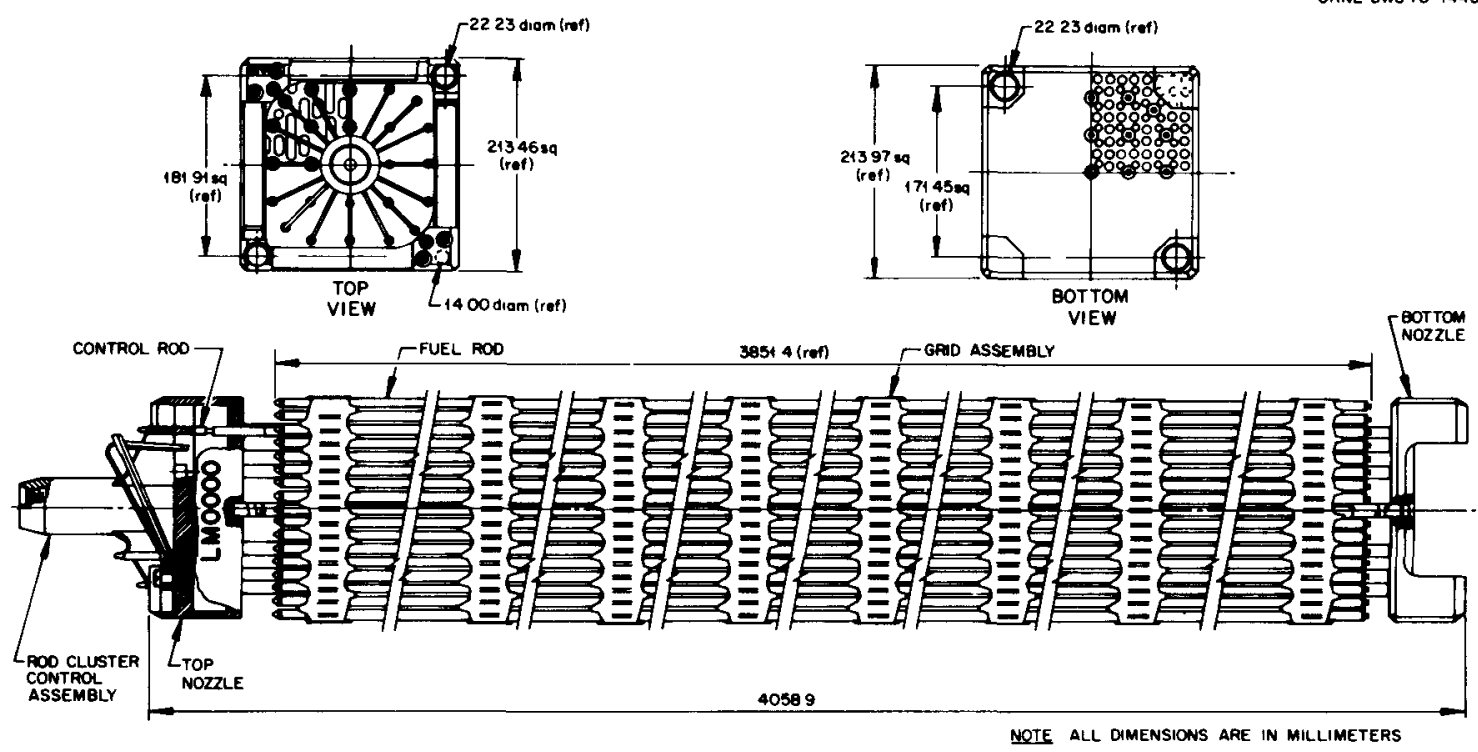

Fig. 1. Westinghouse $17 \times 17$ array PWR fuel assembly. 
Table 1. Components of Combustion Engineering and Westinghouse PWR fuel assemblies

\begin{tabular}{|c|c|c|c|c|}
\hline \multirow{2}{*}{ Component } & \multicolumn{2}{|c|}{ Material } & \multicolumn{2}{|c|}{ Number per fuel assembly } \\
\hline & $C-E$ & W & C.E & W \\
\hline \multicolumn{5}{|l|}{ Guide tubes } \\
\hline Instrument & Zircaloy 4 & Zircaloy-4 & 1 & 1 \\
\hline Control rod & Zircaloy 4 & Zircaloy-4 & 4 & 24 \\
\hline \multicolumn{5}{|l|}{ Spacer grids } \\
\hline Top & Zircaloy 4 & Inconel 718 & 1 & 1 \\
\hline Middle & Zircaloy -4 & Inconel 718 & 10 & 6 \\
\hline Bottom & Inconel 625 & Inconel 718 & 1 & 1 \\
\hline \multicolumn{5}{|l|}{ End fittings (nozzles) } \\
\hline \multirow[t]{2}{*}{ Top } & $\begin{array}{l}304 \mathrm{SS} / \\
\text { Inconel } 750\end{array}$ & $\begin{array}{l}304 \mathrm{SS} / \\
\text { Inconel } 718\end{array}$ & & \\
\hline & Springs & Springs & 1 & 1 \\
\hline Bottom & 304 SS & 304 SS & 1 & 1 \\
\hline Fuel cladding & Zircaloy-4 & Zircaloy-4 & 236 & 264 \\
\hline \multicolumn{5}{|l|}{ End plugs } \\
\hline Top & Zircaloy 4 & Zircaloy-4 & 236 & 264 \\
\hline Bottom & Zircaloy -4 & Zircaloy-4 & 236 & 264 \\
\hline Plenum springs & 302 SS & 302 SS & 236 & 264 \\
\hline Spacers & \multicolumn{2}{|l|}{$\mathrm{Al}_{2} \mathrm{O}_{3}$} & \multicolumn{2}{|l|}{472} \\
\hline Fuel loading (kg HM/fuel assembly) & \multicolumn{2}{|c|}{$\begin{array}{l}\mathrm{UO}_{2},(\mathrm{Pu}, \mathrm{U}) \mathrm{O}_{2} \\
(\mathrm{U}, \mathrm{Th}) \mathrm{O}_{2}(\mathrm{Pu}, \mathrm{Th}) \mathrm{O}_{2}\end{array}$} & $\begin{array}{l}427 \\
388\end{array}$ & $\begin{array}{l}461 \\
432\end{array}$ \\
\hline
\end{tabular}

weld-locked screws threaded into the thimble end plugs. The top grid to top nozzle attachment is accomplished by welding the sleeves of the grid to the top nozzle adapter plate. Axial support of the fuel rods is provided by support springs and dimples in the grids.

The Combustion Engineering fuel assembly consists of 236 fuel rods, 4 control element guide tubes, 1 centrally located instrumentation guide tube, 12 fuel rod spacer grids, upper and lower end fittings, and a hold-down device. The guide tubes, spacer grids, and end fittings form the structural frame of the fuel assembly. The spacer grids and guide tubes are joined by welding, and the end fittings are mechanically attached to the four outer guide tubes. The bottom spacer grid is welded directly to the bottom end fitting. The spacer grids provide frictional axial restraint to fuel rod motion. Figure 2 shows a length view of this fuel assembly, and the components of the assembly are itemized in Table 1.

\subsection{Spectral-Shift Control Reactor Fuels}

Our assumption was that the fuel assembly designs for the SSCR were identical to the PWR fuel assembly designs.

\subsection{Heavy-Water Reactor Fuels}

The reference heavy-water reactor fuel is that used in the Canada deuterium-uranium (CANDU) pressurized heavy-water reactors. 


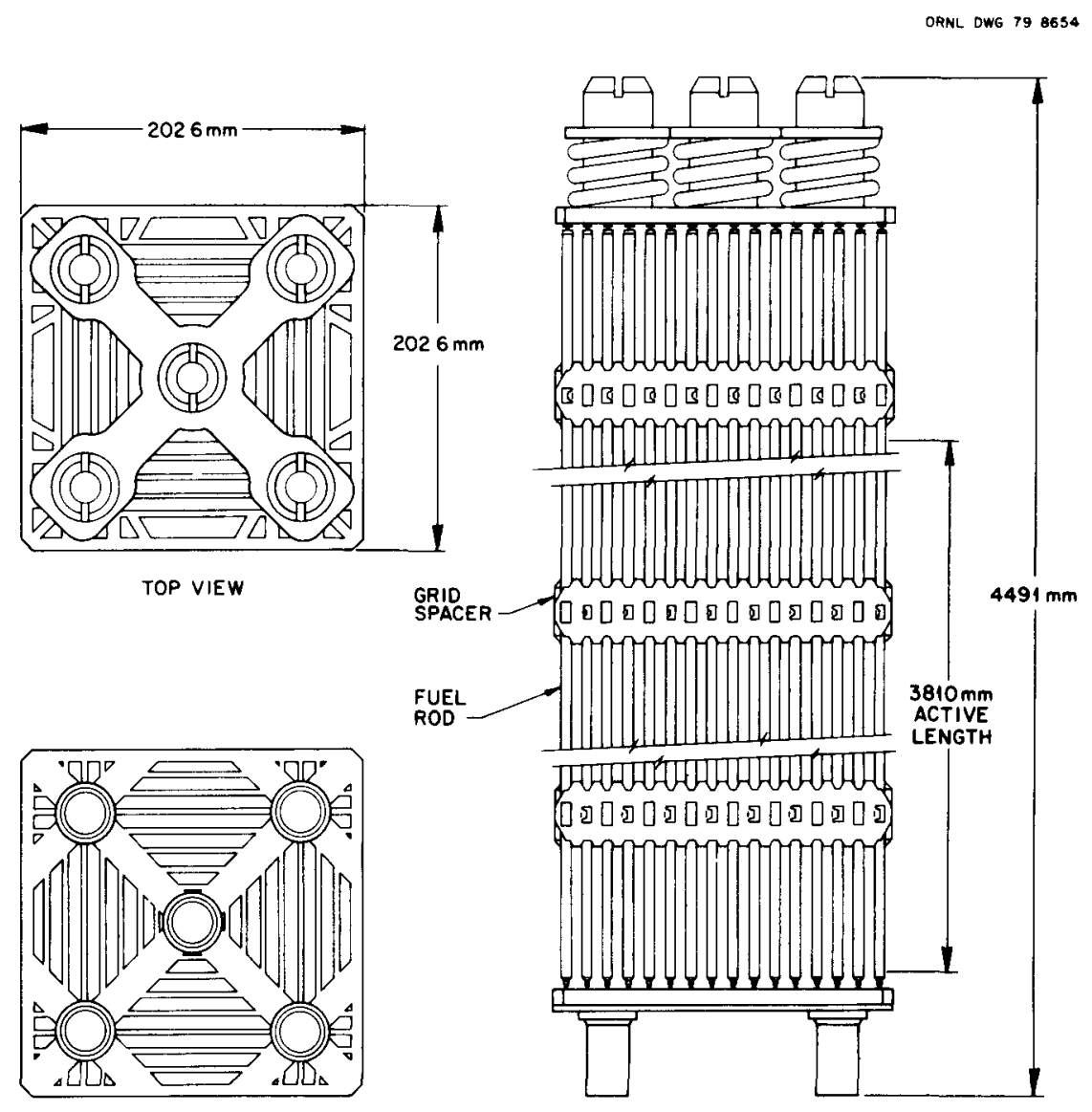

BOTTOM VIEW

Fig. 2. Combustion Engineering system $80-16 \times 16$ array PWR fuel assembly.

The CANDU fuel assembly consists of 37 fuel rods welded to two end plates to form a cylindrical bundle. These end plates maintain separation of the fuel rods at the fuel assembly extremities. The separation of fuel rods at the fuel assembly mid-length is maintained by spacers brazed to the rods. ${ }^{7}$

Support of the fuel assembly within the reactor pressure tubes is provided by bearing pads brazed to the outer fuel rods near the ends of the rods and at their mid-length.

An isometric view of the CANDU fuel assembly is shown in Fig. 3, and the components of the fuel assembly are listed in Table 2 .

\subsection{Liquid-Metal Cooled Fast Breeder Reactor Fuels}

Design parameters for the reference LMFBR fuels (and radial blankets) were provided by Argonne National Laboratory. ${ }^{8}$ Three types of fuels were considered for the LMFBRs - oxides, carbides, and metals. The principal differences in the fuel assemblies are the number of fuel rods contained in each assembly and the heavy-metal content of each assembly.

A length view of a typical LMFBR fuel assembly is shown in Fig. 4, and the design parameters for the core and radial blanket assemblies are summarized in Tables 3 and 4 respectively. 
ORNL OWG 798635

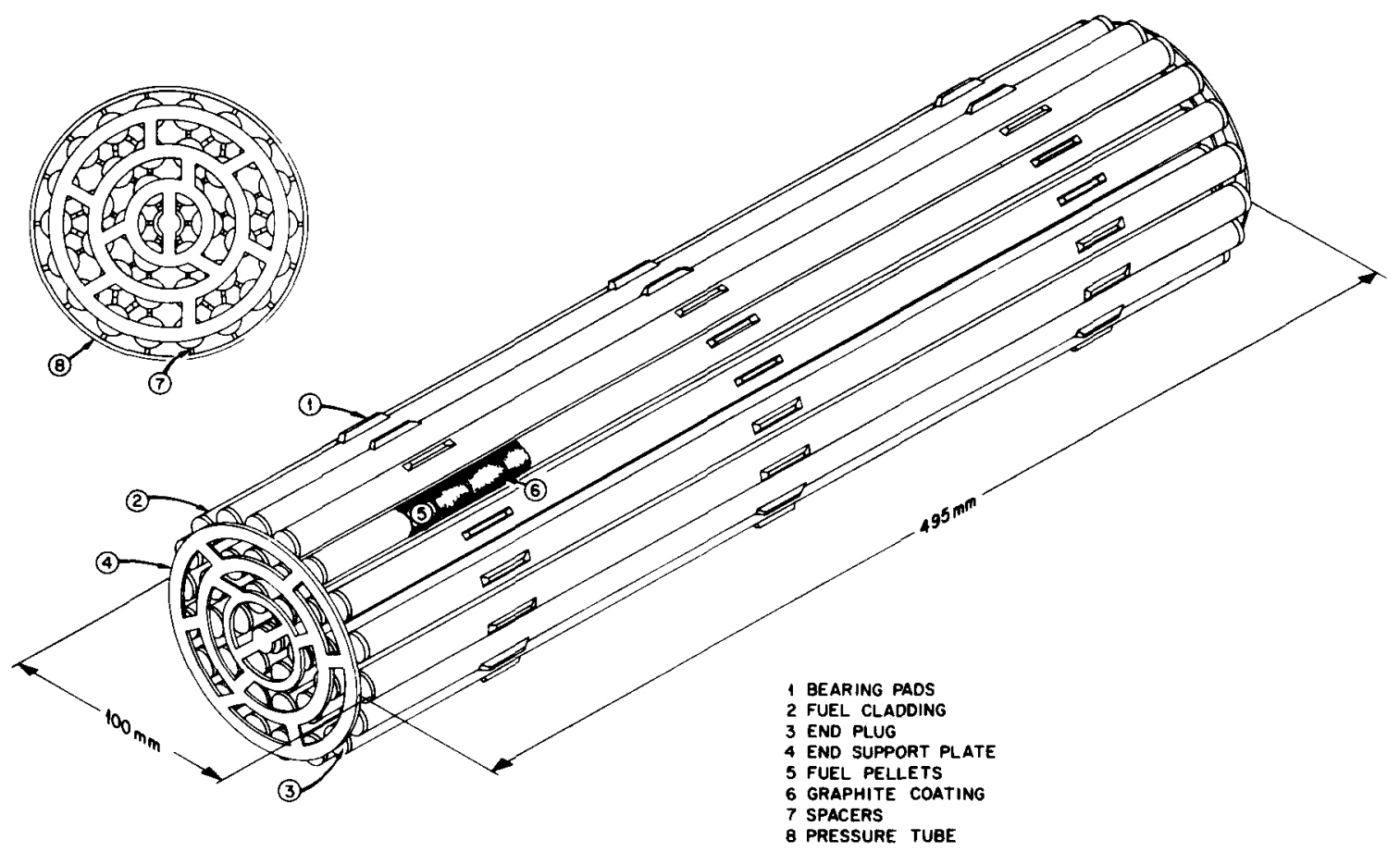

Fig. 3. 37-rod CANDU fuel assembly.

Table 2. Components of CANDU fuel assemblies

\begin{tabular}{|c|c|c|}
\hline Component & Material & umber per fuel assembly \\
\hline Fuel cladding & Zircaloy-4 & 37 \\
\hline \multicolumn{3}{|l|}{ End plugs } \\
\hline Top & Zircaloy -4 & 37 \\
\hline Bottom & Zircaloy-4 & 37 \\
\hline Bearing pads & Zircaloy -4 & 54 \\
\hline Spacers & Zircaloy -4 & 84 \\
\hline \multicolumn{3}{|c|}{ End support plate } \\
\hline Top & Zircaloy-4 & 1 \\
\hline Bottom & Zircaloy -4 & 1 \\
\hline \multicolumn{3}{|c|}{ Fuel loading (kg HM/fuel assembly) } \\
\hline & $\mathrm{UO}_{2},(\mathrm{Pu}, \mathrm{U}) \mathrm{O}_{2}$ & 18.7 \\
\hline & $(\mathrm{U}, \mathrm{Th}) \mathrm{O}_{2},(\mathrm{Pu}, \mathrm{Th}) \mathrm{O}_{2}$ & 16.3 \\
\hline
\end{tabular}




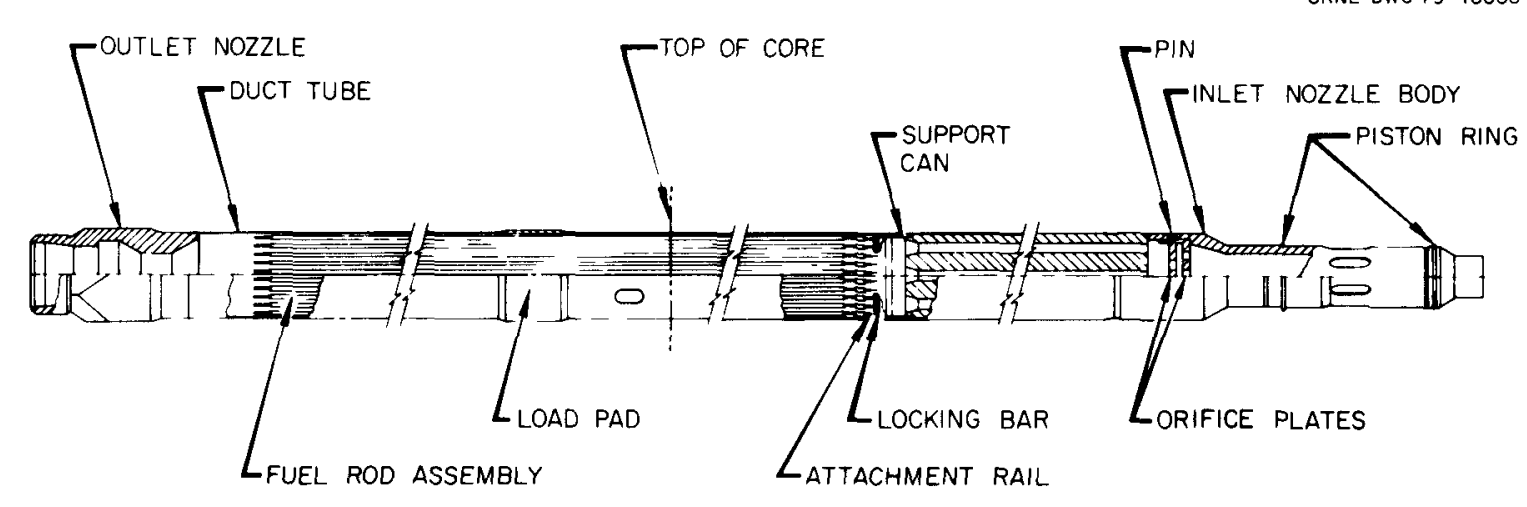

Fig. 4. LMFBR fuel assembly.

Table 3. Design characteristics of fuel used for cost estimations, liquid-metal cooled fast breeder reactors - core and axial blanket ANL NASAP data ${ }^{a}$

\begin{tabular}{|c|c|c|c|}
\hline Characteristics & Oxides & Carbides & Metals \\
\hline Reactor output, MW(e) & $1000^{b}$ & $1000^{b}$ & $1000^{b}$ \\
\hline Fuel assemblies/core & 357 & 258 & 303 \\
\hline Fuel assemblies/reload & 178 & 129 & 151 \\
\hline Bonding & $\mathrm{He}$ & $\mathrm{Na}$ & $\mathrm{Na}$ \\
\hline Fuel rods/assembly & 271 & 169 & 169 \\
\hline Smear density, \% TD & 88 & 86 & $\begin{array}{l}75(\mathrm{U}) \\
85(\mathrm{Th})\end{array}$ \\
\hline Cladding material & $316 \mathrm{SS}$ & $316 \mathrm{SS}$ & $316 \mathrm{SS}$ \\
\hline Cladding outside diameter, $\mathrm{mm}$ (in.) & $7.37(0.290)$ & $8.89(0.350)$ & $8.89(0.350)$ \\
\hline Cladding inside diameter, $\mathrm{mm}$ (in.) & $6.60(0.260)$ & $8.13(0.320)$ & $8.13(0.320)$ \\
\hline Pellet diameter, $\mathrm{mm}$ (in.) & $6.35(0.250)$ & $7.75(0.305)$ & $\begin{array}{l}7.04(\mathrm{U}) \\
(0.277)(\mathrm{U}) \\
7.49(\mathrm{Th}) \\
(0.295)(\mathrm{Th})\end{array}$ \\
\hline Pellet length, mm (in.) & $6.35(0.250)$ & $7.75(0.305)$ & $\begin{array}{l}7.04(\mathrm{U}) \\
(0.277)(\mathrm{U}) \\
7.49(\mathrm{Th}) \\
(0.295)(\mathrm{Th})\end{array}$ \\
\hline $\begin{array}{r}\text { Pellet stack height, total, } \mathrm{mm} \text { (in.) } \\
\text { core, } \mathrm{mm} \text { (in.) }\end{array}$ & $\begin{array}{l}1778(70) \\
1016(40)\end{array}$ & $\begin{array}{l}1778(70) \\
1016(40)\end{array}$ & $\begin{array}{l}1778(70) \\
1016(40)\end{array}$ \\
\hline \multirow{2}{*}{ Fuel } & \multirow{2}{*}{$\begin{array}{c}\text { Density } b \\
(\% \text { TD })\end{array}$} & \multicolumn{2}{|c|}{ Heavy-metal content $(\mathrm{kg})$} \\
\hline & & Rod & Assembly \\
\hline$\left({ }^{23^{3}} \mathrm{U}, \mathrm{Th}\right) \mathrm{O}_{2} / \mathrm{ThO}_{2}$ & 95 & $0.48^{b}$ & $128.9^{b}$ \\
\hline$(\mathrm{Pu}, \mathrm{U}) \mathrm{O}_{2} / \mathrm{UO}_{2}$ & 95 & 0.52 & 140.3 \\
\hline$(\mathrm{Pu}, \mathrm{Th}) \mathrm{O}_{2} / \mathrm{ThO}_{2}$ & 95 & 0.48 & 128.9 \\
\hline$\left({ }^{2}{ }^{3} 3 \mathrm{U}, \mathrm{Th}\right) \mathrm{C} / \mathrm{ThC}$ & 95 & $0.85^{b}$ & $143.1^{b}$ \\
\hline$(\mathrm{Pu}, \mathrm{U}) \mathrm{C} / \mathrm{UC}$ & 95 & 103 & 173.9 \\
\hline$(\mathrm{Pu}, \mathrm{Th}) \mathrm{C} / \mathrm{ThC}$ & 95 & 0.85 & 143.1 \\
\hline${ }^{23} \mathrm{U}, \mathrm{Th} / \mathrm{Th}$ & 100 & $0.98^{b}$ & $164.9^{b}$ \\
\hline $\mathrm{Pu}, \mathrm{U}, \mathrm{Zr} / \mathrm{U}$ & 100 & 1.17 & 198.0 \\
\hline $\mathrm{Pu}, \mathrm{Th} / \mathrm{Th}$ & 100 & 0.98 & 164.9 \\
\hline
\end{tabular}

${ }^{a}$ Y. A. Chang, Argonne National Laboratory, personal communication to J. C. Cleveland, Oak Ridge National Laboratory (April-May 1978).

${ }^{b}$ Assumed values; data not available. 
Table 4. Design characteristics of fuel used for cost estimations, liquid-metal cooled fast breeder reactors - radial blanket ANL INFCE data ${ }^{a}$

\begin{tabular}{|c|c|c|c|c|}
\hline \multicolumn{2}{|c|}{ Characteristics } & Oxides & Carbides & Metals \\
\hline \multicolumn{2}{|c|}{ Reactor output, MW(e) } & $1000^{b}$ & $1000^{b}$ & $1000^{b}$ \\
\hline \multicolumn{2}{|c|}{ Fuel assemblies/core } & 234 & 186 & 204 \\
\hline \multicolumn{2}{|c|}{ Fuel assemblies/reload } & 47 & 37 & 41 \\
\hline \multicolumn{2}{|c|}{ Bonding } & $\mathrm{He}$ & $\mathrm{Na}$ & $\mathrm{Na}$ \\
\hline \multicolumn{2}{|c|}{ Fuel rods/assembly } & 127 & 127 & 127 \\
\hline \multicolumn{2}{|c|}{ Smear density, \% TD } & 90 & 90 & $85^{b}$ \\
\hline \multicolumn{2}{|l|}{ Cladding material } & $316 \mathrm{SS}$ & $316 \mathrm{SS}$ & 316 SS \\
\hline \multicolumn{2}{|c|}{ Cladding outside diameter, $\mathrm{mm}$ (in.) } & $11.94(0.470)$ & $11.99(0.472)$ & $11.71(0.461)$ \\
\hline \multicolumn{2}{|c|}{ Cladding inside diameter, $\mathrm{mm}$ (in.) } & $11.18(0.440)$ & $11.23(0.442)$ & $10.95(0.431)$ \\
\hline \multicolumn{2}{|c|}{ Pellet diameter, mm (in.) } & $10.87(0.428)$ & $10.92(0.430)$ & $10.08(0.397)$ \\
\hline \multicolumn{2}{|c|}{ Pellet length, mm (in.) } & $10.87(0.428)$ & $10.92(0.430)$ & $10.08(0.397)$ \\
\hline Pellet stack heigh & & $70)$ & $1778(70)$ & $1778(70)$ \\
\hline Dlon at meterisl & & & Heav & 1 content $(\mathrm{kg})$ \\
\hline & (\% TD) & $\left(\mathrm{Mg} / \mathrm{m}^{3}\right)$ & Rod & Assembly \\
\hline $\mathrm{UO}_{2}$ & 95 & 10.41 & 1.51 & 192.22 \\
\hline $\mathrm{ThO}_{2}$ & 95 & 9.50 & 1.38 & 174.85 \\
\hline $\mathrm{UC}$ & 95 & 12.95 & 2.05 & 260.42 \\
\hline ThC & 95 & 10.08 & 1.60 & 203.14 \\
\hline $\mathbf{U}$ & 100 & 19.07 & 2.70 & 343.21 \\
\hline Th & 100 & 11.66 & 1.76 & 223.24 \\
\hline
\end{tabular}

${ }^{a}$ W. O. Harms, Oak Ridge National Laboratory, personal communication to P. R. Kasten, Oak Ridge National Laboratory (May 19, 1978).

${ }^{b}$ Assumed values; data not available.

\subsection{High-Temperature Gas-Cooled Reactor Fuels}

The reference HTGR fuel element is the General Atomic Company prismatic design. ${ }^{9}$ Basically, the fuel element consists of a hexagonal prismatic graphite block loaded with particulate fuel contained within fuel rods of carbonized pitch.

An isometric view of the prismatic HTGR fuel element is shown in Fig. 5, and design characteristics of the fuel element are summarized in Table 5.

\section{FABRICATION AND REFABRICATION PROCESSES}

The fabrication processes considered for all metal-clad fuels were similar. All were based on forming pellets (or slugs in the case of metal fuels) of the fuel material and encasing them in the fuel cladding. There are, of course, important differences such as fuel composition, cladding and structural materials, fissile material content, and fuel rod pressurization or atmosphere requirements. Notwithstanding these differences, however, the basic requirements for fabrication of metal-clad fuels are the same - encase the fuel material in metal cladding to form fuel rods and then incorporate a group of these fuel rods into a mechanical assemblage to form the fuel element or assembly.

The fuel element for the HTGR is a hexagonal block of graphite about $79 \mathrm{~cm}(31 \mathrm{in}$.) long and $36 \mathrm{~cm}$ (14 in.) across the flats. The fuel consists of separate coated microspheres containing fissile and fertile material bonded into fuel rods, using a carbonaceous matrix; the fuel rods are then inserted into the 


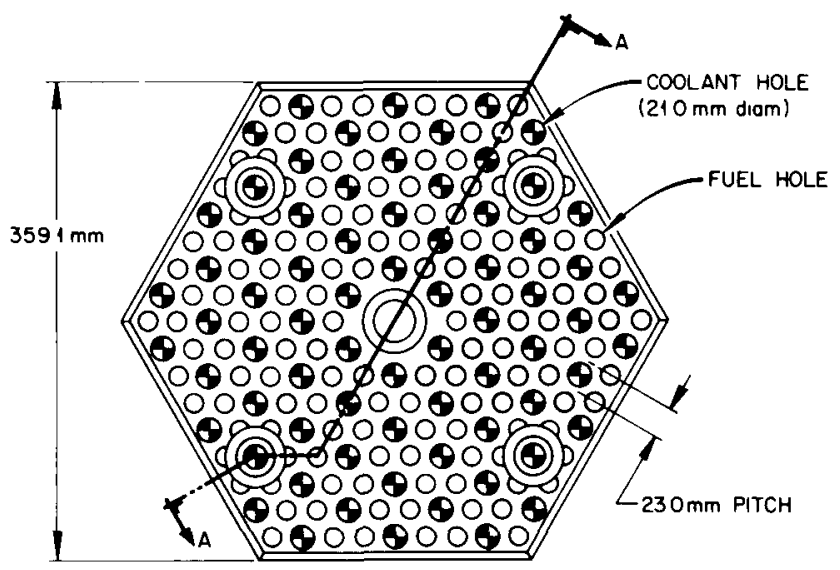

ORNL-DWG 79-12309
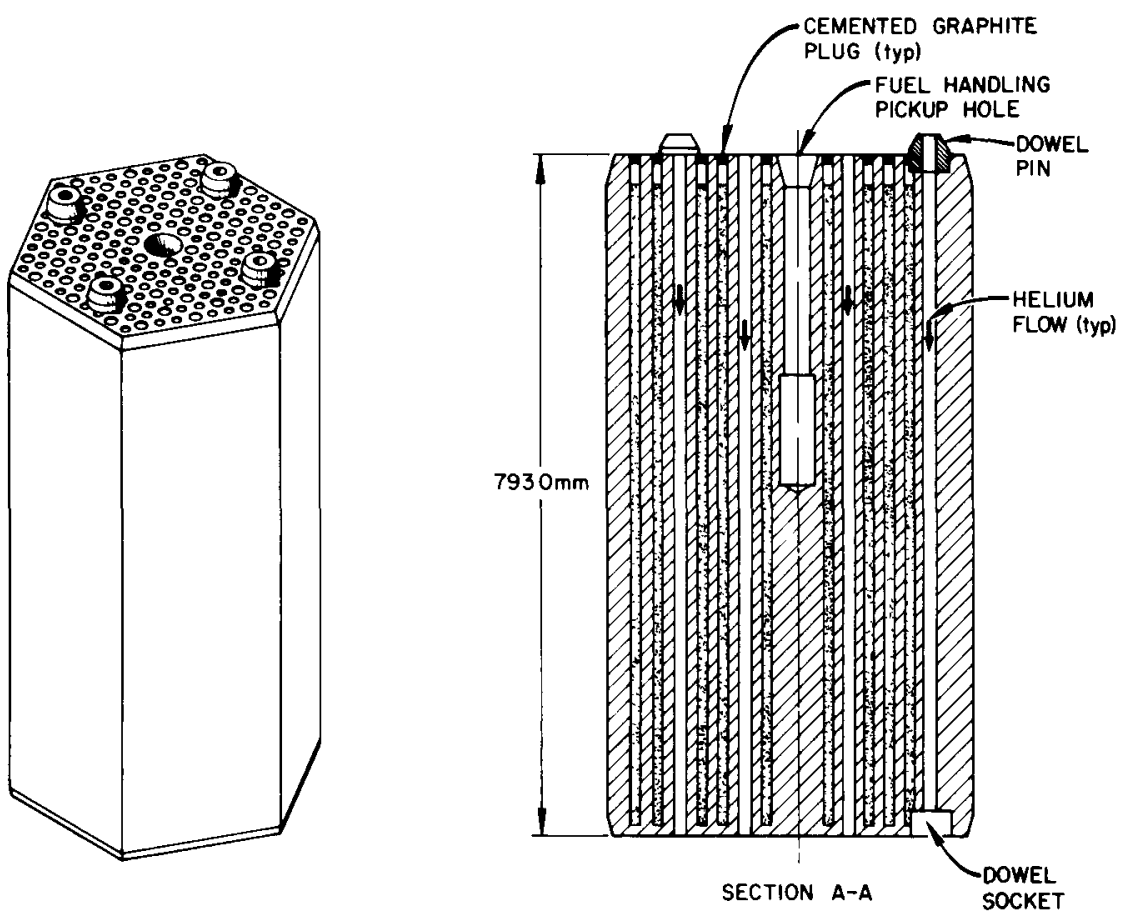

Fig. 5. HTGR standard fuel element.

graphite blocks to form the fuel elements. The fissile and fertile particles are ceramic kernels coated with layers of pyrocarbon with and without an intermediate layer of silicon carbide respectively. This fuel design permits variations in fissile and fertile particle composition and a wide range of fissile-to-fertile and moderator-to-heavy-metal atom ratios without modifying the basic fuel element design. Thus a large number of HTGR fuel cycles are possible without significantly affecting reactor-engineered features. For each reactor fuel concept and management scheme, there will be corresponding changes in the front and back end of the fuel cycle.

Summaries of the fabrication methods selected for this study are presented in the succeeding paragraphs, and these summaries are supplemented by functional flow diagrams that are descriptive of the requirements of the processes. 
Table 5. Design characteristics of fuel used for cost estimations, high-temperature gas-cooled reactors ${ }^{a}$

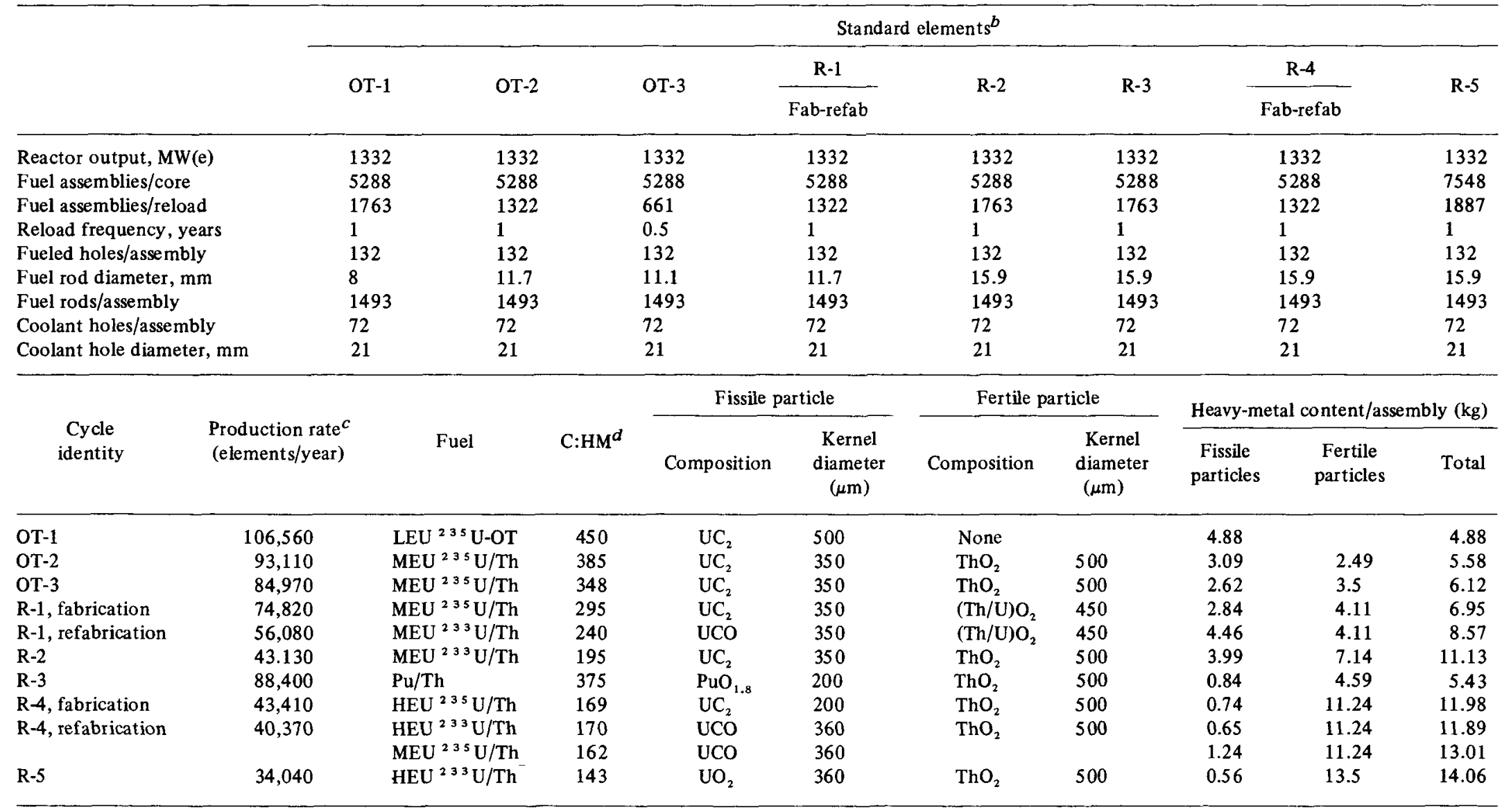

${ }^{a}$ Source is General Atomic data to NASAP, March and July, 1978. A. J. Neylan, General Atomic Company, personal communication to K. O. Laughon, Department of Energy (Mar. 3, 1978); R. K. Lane, General Atomic Company, personal communication to A. R. Olsen, Oak Ridge National Laboratory (July 17, 1978).

${ }^{b}$ Control elements contain fewer fuel holes/assembly and lower heavy-metal contents.

$c^{c}$ Production rate based on HM output of $2 \mathrm{MT} / \mathrm{d}$ at effective full production.

${ }^{d} \mathrm{C}: \mathrm{HM}$ : Ratio of carbon/assembly to heavy metal/assembly. 


\subsection{Pressurized Water Reactor Fuels}

Eight PWR fuels were considered in this study: $\left({ }^{235} \mathrm{U}, \mathrm{U}\right) \mathrm{O}_{2},\left({ }^{23} \mathrm{U}, \mathrm{U}\right) \mathrm{O}_{2},\left({ }^{23} \mathrm{U}, \mathrm{Th}\right) \mathrm{O}_{2}$, $\left({ }^{23} \mathrm{U}, \mathrm{Th}\right) \mathrm{O}_{2},(\mathrm{Pu}, \mathrm{U}) \mathrm{O}_{2}$, spiked $(\mathrm{Pu}, \mathrm{U}) \mathrm{O}_{2},(\mathrm{Pu}, \mathrm{Th}) \mathrm{O}_{2}$, and spiked $(\mathrm{Pu}, \mathrm{Th}) \mathrm{O}_{2}$. In this report the convention for designating fuels will be to identify the fissile material (e.g., ${ }^{2{ }^{3}} \mathrm{U}$ or $\mathrm{Pu}$ ), the fertile or diluent material (e.g., $\mathrm{U}$ or $\mathrm{Th}$ ), and the form of the fuel (e.g., oxides for all PWR cases). Spiking refers to the addition of highly radioactive materials to the fuel.

As stated earlier, two PWR fuel assembly designs were used as references in this study. The Combustion Engineering design (see Fig. 2) was used for $\left({ }^{23} \mathrm{U}, \mathrm{Th}\right) \mathrm{O}_{2}$ and $(\mathrm{Pu}, \mathrm{Th}) \mathrm{O}_{2}$ fuels, and the Westinghouse design (see Fig. 1) was used for all other PWR fuels. The same basic fabrication process may be used for either fuel assembly design. Thus, generic descriptions of the processes are given here with the recognition that minor differences in operations, particularly in fuel assembly fabrication, may be necessary because of differences in design. A schematic summary of the functional operations is given in the flowsheet in Fig. 6 .

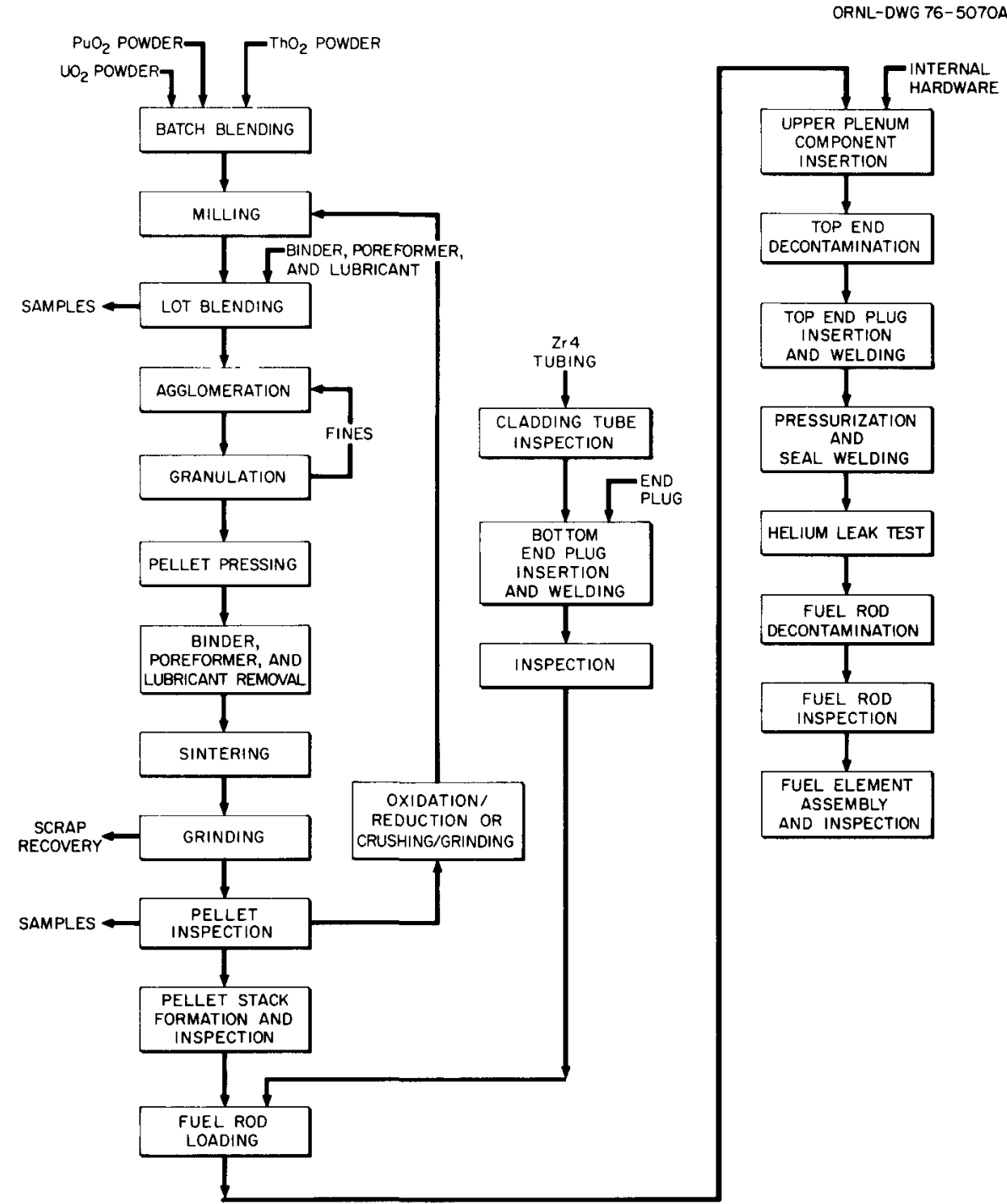

Fig. 6. PWR oxide recycle fuel element fabrication flowsheet. 


\subsubsection{Conversion}

For the contact-operated and -maintained plants - the ${ }^{235} \mathrm{U}$ fuel plants - feed materials include enriched uranium as $\mathrm{UF}_{6}$ and thorium as thorium nitrate tetrahydrate (TNT) crystals.

Conversion of $\mathrm{UF}_{6}$ to $\mathrm{UO}_{2}$ is accomplished by the ammonium diuranate route (see Fig. 7). $\mathrm{UF}_{6}$ in 30-in. (2-ton) cylinders is placed in steam- or electrically heated chests, and the $\mathrm{UF}_{6}$ is vaporized. The vaporized $\mathrm{UF}_{6}$ is transferred to a hydrolysis tank where it is hydrolyzed to uranyl flouride $\left(\mathrm{UO}_{2} \mathrm{~F}_{2}\right)$. The concentration and $\mathrm{pH}$ of the solution are adjusted, and the uranium is precipitated with ammonia as ammonium diuranate (ADU). The ADU slurry is centrifuged and transferred to a rotary calciner for calcination in a reducing $\left(\mathrm{H}_{2}\right)$ atmosphere to $\mathrm{UO}_{2}$. The $\mathrm{UO}_{2}$ powder is blended and placed in interim storage for subsequent processing.

Conversion of TNT to $\mathrm{ThO}_{2}$ is accomplished by the oxalate precipitation process (see Fig. 8). In this process the TNT is dissolved in water, the thorium and free-acid concentrations are adjusted, and the thorium is precipitated as thorium oxalate by addition of oxalic acid. The thorium oxalate slurry is filtered

ORNL-DWG 79-8642

ORNL-OWG 79-8641

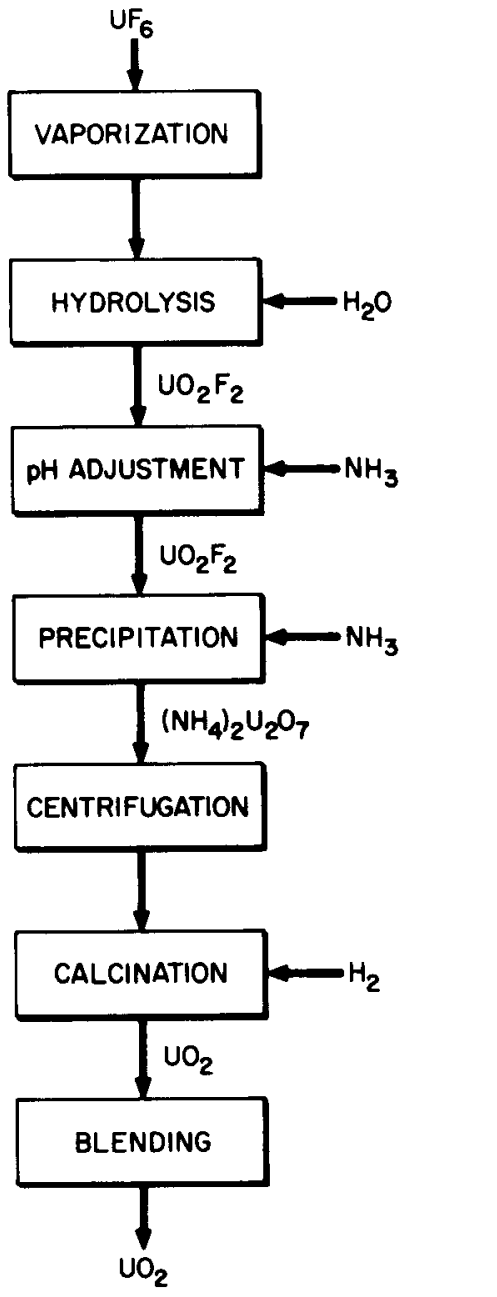

Fig. 7. $\mathrm{UF}_{6}$ to $\mathrm{UO}_{2}$ conversion flowsheet.

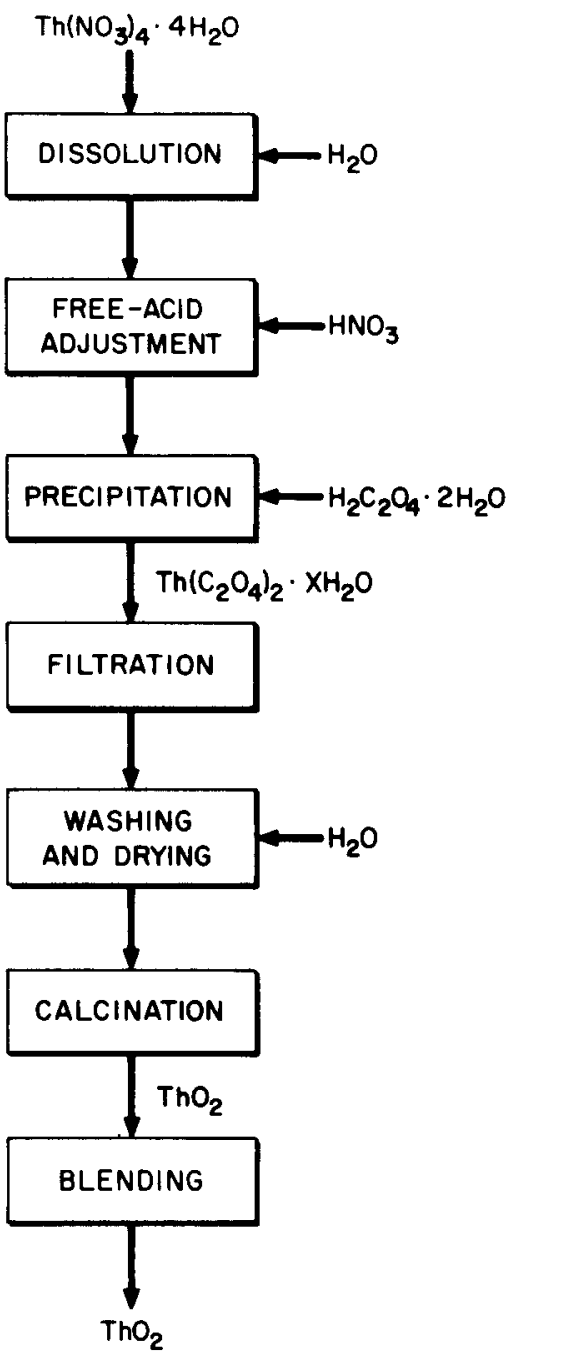

Fig. 8. Th $\left(\mathrm{NO}_{3}\right)_{4} \cdot 4 \mathrm{H}_{2} \mathrm{O}$ to $\mathrm{ThO}_{2}$ conversion flowsheet. 
on a plate-and-frame filter press, washed, and air-dried in the press. The filter cake is removed from the press frames and placed in Inconel boats for calcination to $\mathrm{ThO}_{2}$. This calcination is performed in an air atmosphere at a maximum temperature of $970^{\circ} \mathrm{C}$.

The $\mathrm{ThO}_{2}$ powder is blended to form batches, or lots, of powder, and portions of these lots are then blended with appropriate quantities of $\mathrm{UO}_{2}$ to form the master blend of powder feed for subsequent pelletizing operations.

For the remotely operated plants $-{ }^{233} \mathrm{U}$ and Pu fuels - feed materials are heavy-metal-oxide powders. Thus, conversion operations are not treated as part of these fabrication processes.

\subsubsection{Pelletization}

The pelletization process includes powder preparation, slugging and granulating, lubricant addition, and pressing of the powder into compacts.

Powder preparation may include milling, binder and pore former additions, and drying; or it may simply consist of a milling operation. For our systems, we chose the milling-operation-only option for the powder preparation step.

In order to obtain a free-flowing feed for the pellet press and to obtain an essentially homogeneous feed, usual practice is to press the oxide powder into low-density compacts (the slugging operation) and then granulate the compacts by crushing and screening. The granulated powder is mixed with a solid die lubricant (Sterotex) and transferred to a feed hopper for the pellet press.

The $\mathrm{MO}_{2}$ pellet press feed material is fed to the die cavities of a rotary pellet press and compacted to a green density of 55 to $65 \%$ of the theoretical density of the $\mathrm{MO}_{2}$. These green (green refers to the unfired condition) pellets are placed in molybdenum boats for sintering in a reducing atmosphere in a sintering furnace.

\subsubsection{Sintering and grinding}

The green $\mathrm{MO}_{2}$ pellets are fed into a sintering furnace in the molybdenum boats. The rate of feed and sintering temperatures are established for each batch of $\mathrm{MO}_{2}$ powder by performing sintering (or pilot) tests on the individual batches of powder. The activity (sinterability) of the powder varies somewhat from batch to batch, and the sintering test is the most reliable method for establishing appropriate sintering conditions. Depending on the powder used, periods from 4 to $8 \mathrm{hr}$ at temperatures of 1500 to $1800^{\circ} \mathrm{C}$ may be required to obtain acceptable pellets.

Subsequent to the sintering operation, the acceptability of the density of the pellets is established, and the pellets are ground to the proper diameter, using a centerless grinder. Either wet or dry grinders may be used, but if wet grinding is selected, a subsequent drying operation is required.

The sintered and ground $\mathrm{MO}_{2}$ pellets are formed into stacks and are staged for loading into fuel rods.

\subsubsection{Fuel rod loading}

The pellet stacks are transferred to a vibratory loader, weighed, and loaded into fuel rods (the fuel rods at this point already have their bottom end plugs welded in place). The stack height and plenum gap of each rod are verified, the lip area of the upper end of the loaded rod is decontaminated, a plenum spring is inserted, and the top end plug is inserted and welded. The fuel rod is pressurized with helium to a prescribed level through a pressurization hole in the top end plug, and this hole is welded to seal the rod. 


\subsubsection{Fuel rod inspection}

Fuel rod inspection operations include $x$-ray inspection of weld areas, fluoroscopic examination of the rods for pellet chips or voids, leak detection, rod assay, and dimensional inspections.

The loaded and welded rods are transferred to the fluoroscope station, where all rods are visually scanned to verify the integrity of the pellet stack. This includes checks for pellet chips or voids and proper plenum gap.

From the fluoroscope station, the fuel rods are transferred to the $x$-ray station, where the welded areas of the top and bottom end plugs are inspected. These inspections include radiographic examinations of the plug-to-tubing girth welds and the top end plug seal weld.

The leak detection system consists of several evacuation chambers that can accommodate 25 to 50 fuel rods each and a helium mass spectrometer system. After the fuel rods are loaded and the chambers are evacuated, the chambers are valved to the mass spectrometer system. Since the rods are pressurized with helium, an indication of helium by the mass spectrometer indicates a leak in at least one rod. If a leaking rod is detected, the rods are subdivided and retested until all leaking rods are positively identified and removed for rework or repair.

All fuel rods are assayed to verify proper fissile material content. For the unspiked fuels, the assay device is an active gamma scanner. The use of this device involves exposing the fuel rods to a timecontrolled neutron flux (generally ${ }^{252} \mathrm{Cf}$ source) and then counting the fission product gamma radiation. For the spiked fuels, this method is not applicable because of the high levels of gamma radiation associated with the spiking material. For these fuels, an assay device that provides for counting of prompt and delayed fission neutrons is used.

Dimensional inspections include fuel rod length, straightness, and outside-diameter verification. These inspections are performed on automated equipment calibrated by use of standard acceptable rods.

In all inspection operations, automated transfer systems provide for segregation of acceptable and unacceptable fuel rods. Unacceptable fuel rods are reworked or repaired, as appropriate.

\subsubsection{Fuel assembly fabrication}

A prefabricated fuel assembly skeleton is positioned in the fuel assembly loading station. Acceptable fuel rods are pulled from a loading rack or magazine into the skeleton, to which the end fittings are attached. During the loading of fuel rods into the assembly skeleton, all components are in a horizontal position. Subsequent to securement of the end fittings to the loaded assembly, the assembly is rotated to a vertical position and transported to the fuel assembly inspection area. All subsequent operations are performed with the fuel assembly in a vertical position.

\subsubsection{Fuel assembly inspection}

Fuel assembly inspection operations include verification of acceptability of several dimensional characteristics that include length, fuel rod spacing, bow and twist, and tilt. All of these operations are amenable to the use of automated inspection equipment, and we envisioned the use of such equipment in these inspections.

Subsequent to verification of the dimensional characteristics of the fuel assemblies, they are washed and dried, inspected for cleanliness, checked to assure the ability to accept control elements, and finally packaged for shipment. For the unspiked fuels, fuel assembly shipping containers of the type currently in 
use by the commercial fuel vendors are used. For the spiked fuels, modified spent fuel shipping casks are used. The fuel assemblies are placed in a support frame of the shipping container and rotated to a horizontal position in the container. The container is sealed and placed in interim storage for loading onto the shipping vehicle.

\subsection{Heavy-Water Reactor Fuels}

Nine HWR fuels were addressed in this study: $\mathrm{UO}_{2}$ (natural), $\left({ }^{255} \mathrm{U}, \mathrm{U}\right) \mathrm{O}_{2},\left({ }^{23} \mathrm{U}, \mathrm{U}\right) \mathrm{O}_{2},\left({ }^{235} \mathrm{U}, \mathrm{Th}\right) \mathrm{O}_{2}$, $\left({ }^{2}{ }^{3} \mathrm{U}, \mathrm{Th}\right) \mathrm{O}_{2},(\mathrm{Pu}, \mathrm{U}) \mathrm{O}_{2}$, spiked $(\mathrm{Pu}, \mathrm{U}) \mathrm{O}_{2},(\mathrm{Pu}, \mathrm{Th}) \mathrm{O}_{2}$, and spiked $(\mathrm{Pu}, \mathrm{Th}) \mathrm{O}_{2}$. The fuel assembly design was described earlier in this report, and it was assumed that the same design was appropriate for all the fuels considered. The fuel fabrication process is similar to that used for PWR fuels, and the reader will be referred to certain sections of the PWR fuel fabrication discussion. Reference is also made to the fabrication flowsheet presented in Fig. 9.

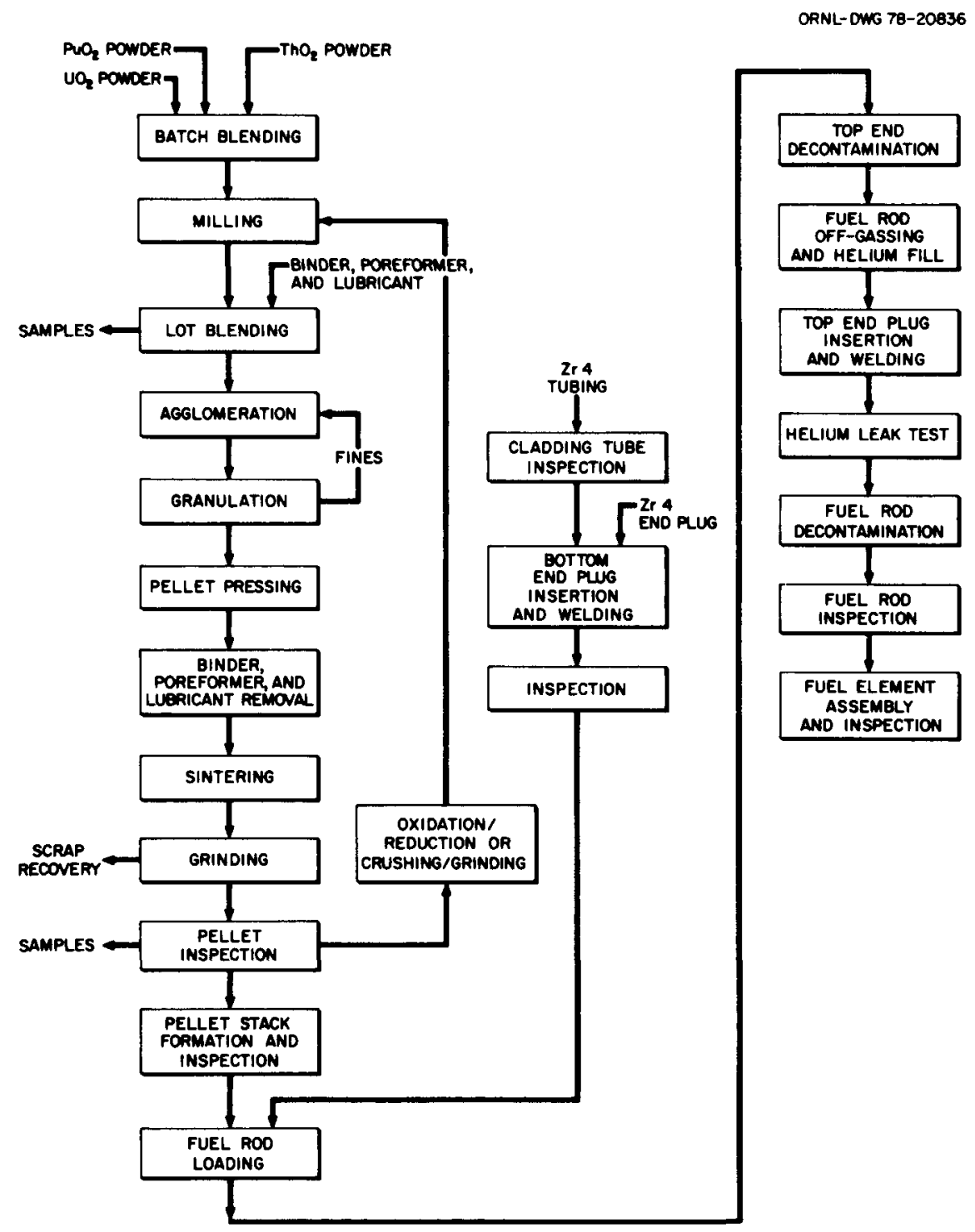

Fig. 9. HWR oxide recycle fuel element fabrication flowsheet. 


\subsubsection{Conversion}

Conversion operations are applicable only to the contact operation facilities, and the methods for $\mathrm{UF}_{6}$ to $\mathrm{UO}_{2}$ and $\mathrm{Th}\left(\mathrm{NO}_{3}\right)_{4} \cdot 4 \mathrm{H}_{2} \mathrm{O}$ to $\mathrm{ThO}_{2}$ conversions are identical to those described for the PWR fuels.

\subsubsection{Pelletization}

The pelletization process for HWR fuels is identical to that described for PWR fuels, even though the sizes of the pellets differ somewhat.

For the high-burnup HWR fuels, a slight variation in pellet design is necessary. Annular pellets in the upper ends of these fuel rods provide fission gas plenums. However, this variation does not impact appreciably on the pelletization operation. A modification of the punch and die system is made to form the annular pellets.

\subsubsection{Sintering and grinding}

Sintering and grinding of the HWR fuel pellets are identical to the operations described for PWR fuels.

\subsubsection{Fuel rod loading}

Loading of HWR fuel rods is quite similar to the technique described for PWR fuel rods. The HWR fuel rods are much shorter than the PWR rods and hence require fewer pellets per rod. The differences that exist are primarily related to handling of the rods; that is, many more smaller rods must be loaded. Thus, more fuel rod loading and welding stations are required, but more rods pass through the process operation per unit of time.

The HWR fuel rods do not require plenum hardware or pressurization (the rods are backfilled with helium to a very slight positive pressure). Thus these operations are not included in the fabrication lines.

\subsubsection{Fuel rod inspection}

The basic inspections for HWR fuel rods are the same as those for PWR fuel rods.

\subsubsection{Fuel assembly fabrication}

Fuel rods for the HWR are equipped with external spacers and bearing pads to provide rod-to-rod and fuel assembly-to-pressure tube spacing respectively. These appendages are brazed to the tubes prior to loading with pellets.

The fuel rods are collected and assembled in a welding fixture. End plates are attached to the bundle of rods by resistance welding of the end plates to the end plugs of the fuel rods. Fabrication of HWR fuel assemblies is very simple and straightforward compared with the fabrication of PWR fuel assemblies.

\subsubsection{Fuel assembly inspection}

Inspection of HWR fuel assemblies consists of verification of dimensional characteristics, inspection of end-plate welds, and verification of cleanliness. For those fuel assemblies that have fuel rods with plenums, an inspection of rod placement, that is, plenum position of individual rods within the assembly, is required.

Subsequent to the inspection operations, the fuel assemblies are cleaned and packaged for shipment. As was the case with spiked PWR fuels, spiked HWR fuels are shipped in modified spent-fuel shipping casks, and fresh fuels are shipped in the shipping containers used by the commercial vendors. 


\subsection{Liquid-Metal-Cooled Fast Breeder Reactor Fuels}

Sixteen LMFBR fuels and nine radial blanket fuels were addressed in this study and included oxides, carbides, and metals. Flowsheets for the various fuel types are presented in Figs. 10-12. A general description of the fabrication process for each type of fuel is presented, and in those instances where identical operations are involved, the reader is referred to the appropriate sections.

The basic fuel assembly design was presented earlier in this report, and this basic design is applicable to all the fuel and radial blanket assemblies. There are, of course, important differences such as number of fuel rods in an assembly, but these differences are not relevant to the present discussion.

\subsubsection{Oxide fuels}

3.3.1.1 Conversion. Conversion is applicable to only one of the LMFBR core assembly fuels $\left({ }^{235} \mathrm{U}, \mathrm{Th}^{3}\right) \mathrm{O}_{2} / \mathrm{ThO}_{2}$ - and to six of the radial blanket cases. In all other cases, feed material to the fabrication plant is the product of a conversion process performed at the reprocessing plant.

Two conversion processes are important to this discussion - the conversion of $\mathrm{UF}_{6}$ to $\mathrm{UO}_{2}$ and the conversion of $\mathrm{Th}\left(\mathrm{NO}_{3}\right)_{4} \cdot 4 \mathrm{H}_{2} \mathrm{O}$ to $\mathrm{ThO}_{2}$. These conversion processes were described in the discussion of pressurized water reactor fuel fabrication.

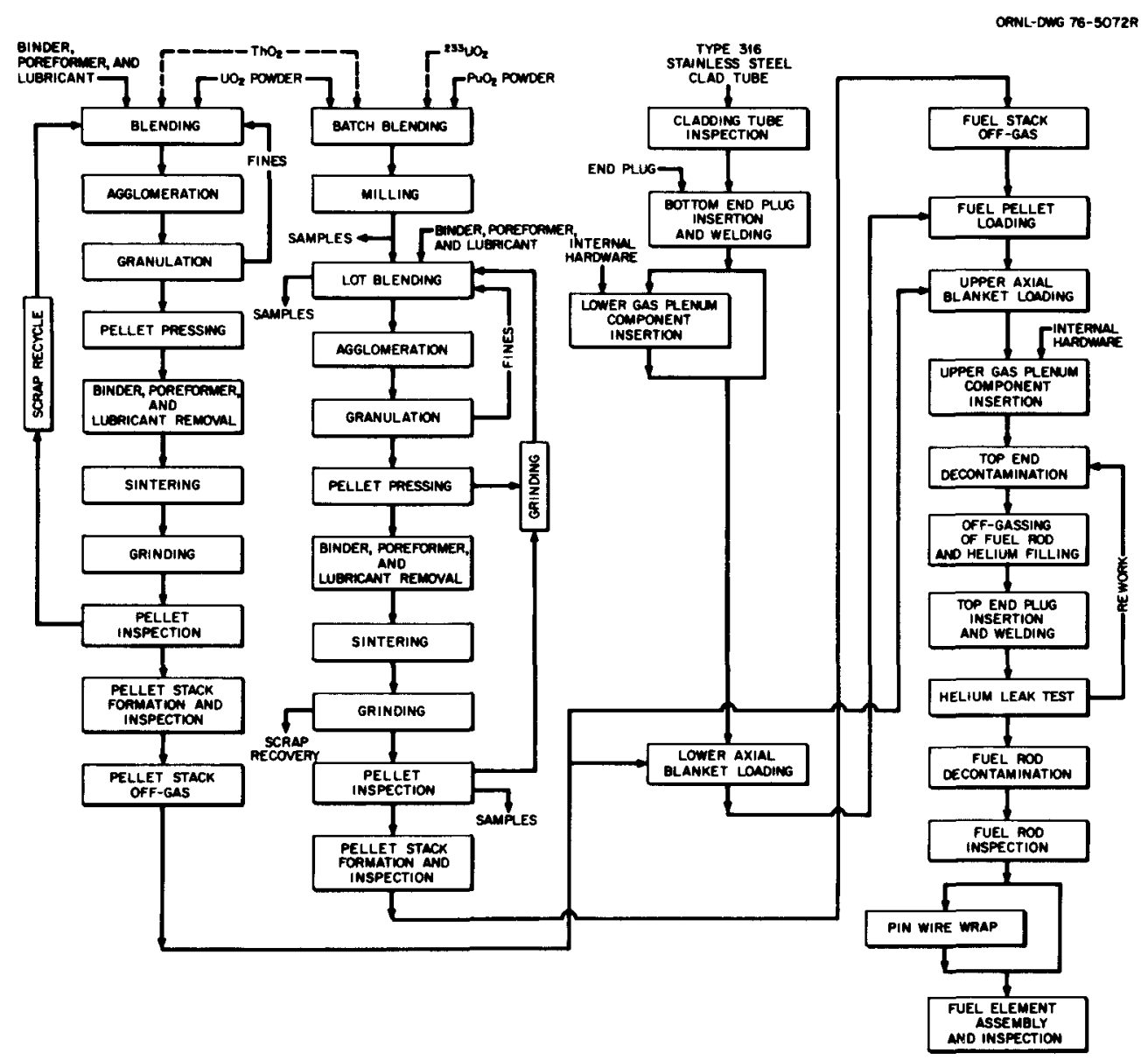

Fig. 10. FBR oxide fuel element fabrication flowsheet. 


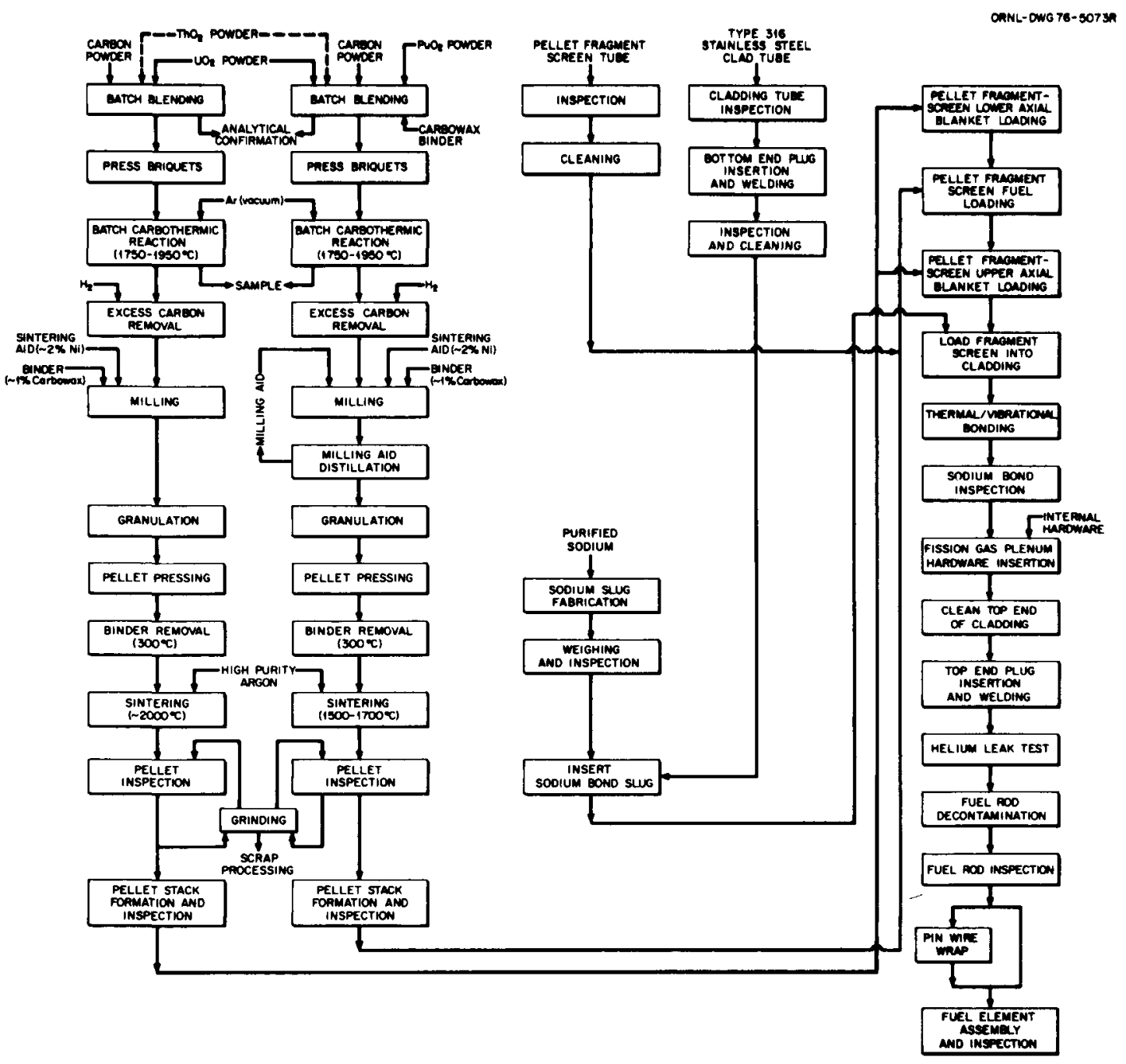

Fig. 11. FBR carbide fuel element fabrication flowsheet.

3.3.1.2 Powder receipt and preparation. Feed materials for the ${ }^{233} \mathrm{U}$ and $\mathrm{Pu}$ fuels are the heavy-metal oxides. These powders are received as master mixes from the reprocessing plant. For the ${ }^{23}{ }^{3} \mathrm{U}$ and spiked $\mathrm{Pu}$ fuels, the powders are shipped in shielded casks. The oxide powders are transferred into the interim storage area of the fabrication plant and are weighed, sampled, and analyzed to verify that specification requirements are met. Typical analyses include isotopic distribution, homogeneity, particle size and/or surface area, impurities, moisture, and oxygen-to-metal ratios.

3.3.1.3 Pelletization. Acceptable powders are subdivided, blended, milled, and combined with necessary lubricants, binders, and pore formers. These well-blended mixtures are then slugged and granulated as described for PWR fuels. All pelletization operations are essentially identical to those discussed for PWR fuels.

3.3.1.4 Sintering and grinding. Sintering and grinding operations are the same as those described for PWR fuels. 


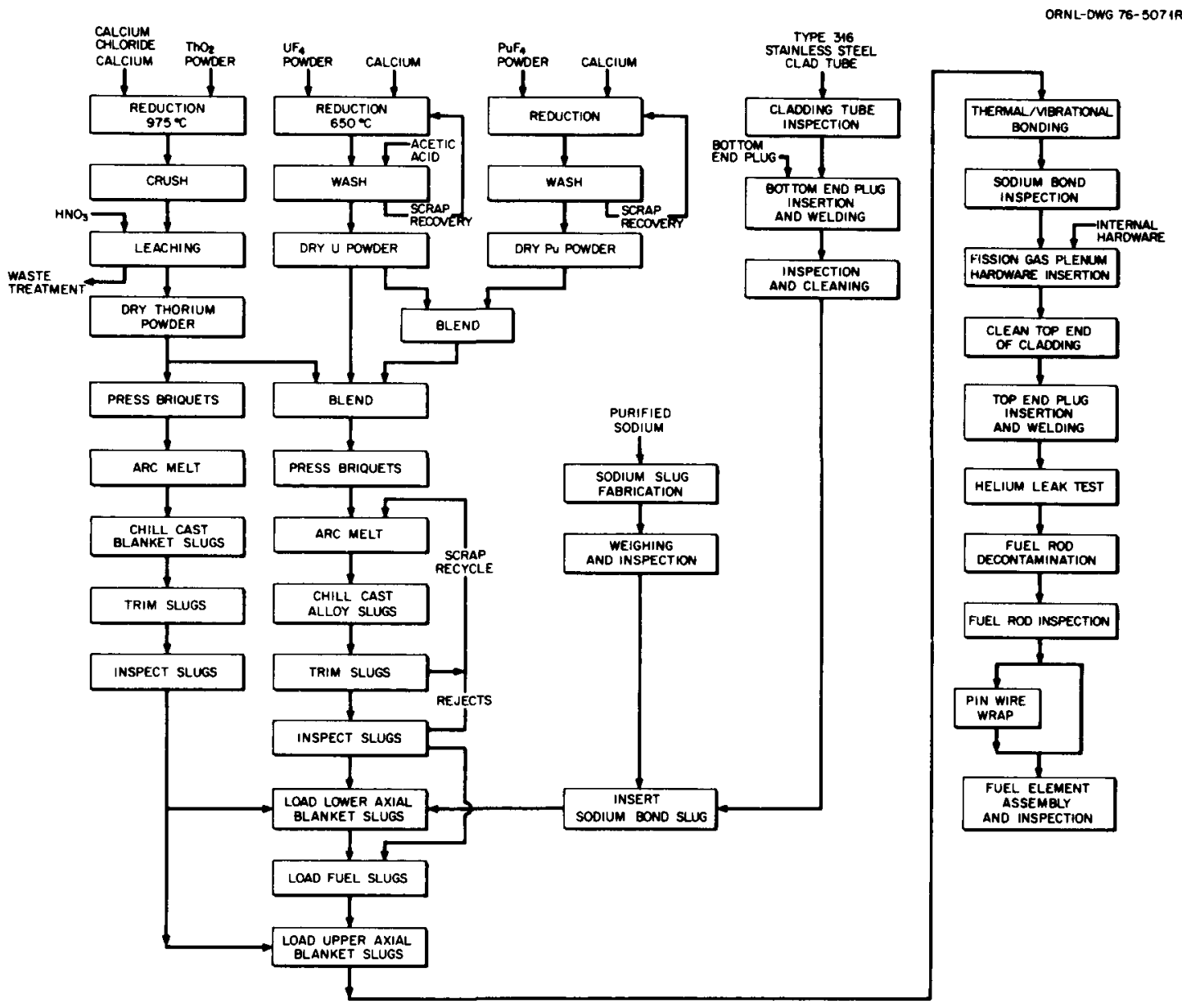

Fig. 12. FBR metal fuel element fabrication flowsheet.

3.3.1.5 Fuel rod loading. Loading of LMFBR fuel rods is quite similar to the loading of PWR fuel rods. However, there are some important differences.

The first end-plug welding and lower plenum hardware insertion are performed in the hardware fabrication portion of the facility and are inspected prior to transfer to the fuel rod loading area. Axial blanket pellets (natural or depleted $\mathrm{UO}_{2}$ or $\mathrm{ThO}_{2}$ ) are received from a vendor, inspected, placed in interim storage, and transferred, as needed, to the fuel rod loading area. The lower axial blanket pellets, fuel pellets, upper axial blanket pellets, and upper plenum hardware are loaded into fuel rods. The rods are evacuated and backfilled with helium, and the top end plug is inserted and welded. The fuel rods are inspected for weld integrity by $\mathrm{x}$-ray techniques, leak tested, assayed, and inspected for dimensional characteristics.

Wrapping wire is applied to each fuel rod by inserting one end of the wire into an end plug hole and spot-welding the wire to the plug. The rod is rotated to wind the wire. The proper spiral is assured by a fixture that moves along the length of the rod as the rod is rotated. The end of the wire is clamped, cut to proper length, inserted into a hole in the second end plug, and spot-welded. These wire-wrapped fuel rods are inspected and placed in storage prior to fuel assembly.

3.3.1.6 Fuel assembly. Wire-wrapped fuel rods are assembled into layers (called strip layers), which are loaded in sequence into the lower shield and nozzle assembly and locked in place. The hexagonal duct or 
shroud, with upper handling socket, is placed over the fuel rods, rested against the lower shield and nozzle assembly, and welded in place. The completed assembly is dimensionally inspected, weighed, and cleaned prior to transport to a storage area. Fuel assemblies are stored vertically and are transported on a stiff frame to the shipping container loading area. There, they are rotated to a horizontal position, and the shipping container is secured.

\subsubsection{Carbide fuels}

3.3.2.1 Conversion. For the fabrication of $\mathrm{UC}$ and $\mathrm{ThC}$ radial blanket assemblies, conversion processes include $\mathrm{UF}_{6}$ to $\mathrm{UO}_{2}$ to $\mathrm{UC}$, and $\mathrm{Th}\left(\mathrm{NO}_{3}\right)_{4}$ to $\mathrm{ThO}_{2}$ to ThC. The $\mathrm{UF}_{6}$ to $\mathrm{UO}_{2}$ and the $\mathrm{Th}\left(\mathrm{NO}_{3}\right)_{4}$ to $\mathrm{ThO}_{2}$ conversion processes were described for the PWR fuels, and these processes are applicable here.

After conversion of the feed materials to $\mathrm{UO}_{2}$ or $\mathrm{ThO}_{2}$ [or receipt of oxide powders for the ${ }^{23} \mathrm{U}$ and plutonium fuels or radioactively contaminated (recycled) $\mathrm{ThO}_{2}$ ], conversion to the carbides is accomplished by a batch carbothermic reaction in which the heavy-metal oxides are reacted with elemental carbon at 1750 to $1950^{\circ} \mathrm{C}$. Excess carbon is removed by reaction with hydrogen.

3.3.2.2 Pelletization. The carbide powders are milled, and a binder and sintering aid are added. The powders are slugged, granulated, and then pressed into pellets.

3.3.2.3 Sintering and grinding. The pellets are heated in an argon atmosphere to remove the binder and are sintered in argon to high density. The pellets are visually inspected for structural defects and are ground to size on a centerless grinder. Acceptable pellets are accumulated for pellet stack formation and inspection.

3.3.2.4 Fuel rod loading. Because of the tendency of carbide pellets to chip or fragment, a metal screen or shroud is used as a liner for the fuel cladding. Axial blanket pellets are received from a vendor, inspected, and loaded into the fragment screen. Fuel pellets are loaded, and the upper axial blanket pellets are loaded into the fragment screen. Fuel cladding equipped with a lower end plug is transferred to the fuel rod loading area. A purified sodium metal slug and the loaded fragment screen are inserted into the cladding. The loaded rod is heated and vibrated to fill the void space in the fuel rod with sodium. This sodium bond is inspected to assure that all voids are filled. Fission-gas plenum hardware is inserted, the top end of the cladding is cleaned, and the top end plug is inserted and welded to the cladding. The finished fuel rod then proceeds through the same inspection processes as do the LMFBR oxide fuel rods.

It is especially important to note that because of the pyrophoricity of the heavy-metal carbides and the ease of oxidation of sodium, all operations involving the handling of these materials are performed in dry inert-gas atmospheres.

The heavy-metal carbide fuel rods are wire-wrapped in the same manner as are the oxide fuel rods.

3.3.2.5 Fuel assembly. Fuel assembly fabrication and inspection are the same as described for the LMFBR oxide fuels.

\subsubsection{Metal fuels}

3.3.3.1 Conversion. Conversion processes are applicable to all metal fuels. For the uranium (contact) radial blanket fabrication plants, $\mathrm{UO}_{2}$ is prepared from $\mathrm{UF}_{6}$ by the $\mathrm{ADU}$ process. $\mathrm{The}_{2} \mathrm{UO}_{2}$ is converted to $\mathrm{UF}_{4}$ (green salt) by hydrofluorination. The $\mathrm{UF}_{4}$ is the feed material for metal fabrication.

For thorium metal production, $\mathrm{ThO}_{2}$ is prepared by the oxalate process, and this $\mathrm{ThO}_{2}$ is used as the feed for metal production.

For plutonium metal production, $\mathrm{PuO}_{2}$ is hydrofluorinated to $\mathrm{PuF}_{4}$, which is the feed material for metal production. 
3.3.3.2 Reduction and casting. The uranium and plutonium fluorides and thorium oxide may all be reduced by calcium to their elemental forms. The product in each instance is a metal powder that is pressed into briquets, melted in a vacuum induction furnace, cast into billets, scalped, and chill-casted into metal fuel slugs. All operations involved with the handling of the dry metal powders, molten metals, or hot metals are performed in inert atmospheres or in vacua.

3.3.3.3 Fuel rod loading. The metal slugs are formed into stacks for fuel rod loading. Axial blanket slugs are obtained from a vendor, inspected, and transferred to the rod loading station. A purified sodium metal slug is inserted. The lower axial blanket, core, and upper axial blanket fuel slugs are loaded into the cladding. Bonding is accomplished by the thermal-vibrational technique described for the carbide fuels. The sodium bond is inspected, and the upper plenum hardware and end plug are inserted. The upper end plug is welded and inspected, the wire wrap is applied and inspected, and the fuel rod is transferred to storage prior to fuel assembly fabrication and inspection.

3.3.3.4 Fuel assembly fabrication and inspection. Metal fuel assembly fabrication and inspection is performed in the same manner as for the carbide fuels.

\subsection{High-Temperature Gas-Cooled Reactor Fuels}

The specific cycles addressed in this study are those described in two other papers addressing the reactor characteristics. Three once-through cycles with stowaway of the spent fuel are: ${ }^{10}$ (1) the HTGR once-through current MEU/Th cycle, (2) the HTGR once-through optimized MEU/Th cycle, and (3) the HTGR once-through LEU cycle. A second paper ${ }^{11}$ discusses reactor characteristics for the HTGRs utilizing fuel with recycle options. Three primary cycles involving two with denatured uranium and a plutonium converter are supplemented with two cycles involving highly enriched uranium. The cycles are: (1) the

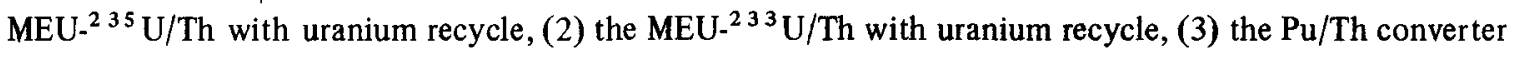
with plutonium recycle and ${ }^{233} \mathrm{U}$ makeup, and (5) the HEU. ${ }^{23} \mathrm{U} / \mathrm{Th}$ cycle with highly enriched ${ }^{233} \mathrm{U}$ makeup from an external source.

A summary description of the fresh (unirradiated) fuel elements for each cycle is given in Table 6, and the reactor mass discharge data are given in Table 7. Both tables are based on the fuel requirements and reactor mass flow for the equilibrium cycle.

Both fabrication and refabrication involve essentially the same process steps as shown in Figs. 13 and 14. The essential differences are only in the operational modes. Fresh fuel can be processed with direct operator-equipment interfacing and hands-on equipment maintenance in a standard fuel manufacturing type of facility. Recycle fuel requires heavy shielding around the process equipment and remote operation and equipment maintenance.

A simplified functional flow diagram for both fabrication and refabrication is presented in Fig. 14 to assist in the description. The main functional areas have been numbered 1 through 7 , while the typical interfaces for a refabrication plant are shown in the unnumbered boxes surrounded by dotted lines.

The following sections are brief descriptions of the processes in each of the functional areas.

\subsubsection{Fuel receiving and storage}

In a fabrication plant the principal inputs are uranium as enriched $\mathrm{UF}_{6}$ and thorium as $\mathrm{ThO}_{2}$ or $\mathrm{Th}\left(\mathrm{NO}_{3}\right)_{4}$. These are stored and used as the feed to the fuel kernel fabrication processes. In a refabrication plant the uranium is typically received from a colocated reprocessing plant as uranyl nitrate solution or as preformed oxide microspheres from a remote reprocessing plant. For some of the fuel cycles discussed in 
Table 6. Average fresh fuel element description at equilbrium

\begin{tabular}{|c|c|c|c|c|c|c|c|c|}
\hline \multirow{2}{*}{ Characteristics } & \multicolumn{3}{|c|}{ Onœ-through cycles } & \multicolumn{5}{|c|}{ Recycle cycles } \\
\hline & $\begin{array}{l}\text { LEU } \\
\text { OT } 1\end{array}$ & $\begin{array}{l}\text { MEU-Th } \\
\text { dnnual } \\
\text { OT2 }\end{array}$ & $\begin{array}{l}\text { MEU-Th } \\
\text { semiannual } \\
\text { OT3 }\end{array}$ & $\begin{array}{c}\text { MEU }{ }^{235} \mathrm{U} / \mathrm{Th} \\
3 \mathrm{yr} \\
\mathrm{R} 1\end{array}$ & $\begin{array}{c}\mathrm{MEU}^{2{ }^{23}} \mathrm{U} / \mathrm{Th} \\
3 \mathrm{yr} \\
\mathrm{R} 2\end{array}$ & $\begin{array}{c}\mathrm{Pu} / \mathrm{Th} \\
3 \mathrm{yr} \\
\mathrm{R} 3\end{array}$ & $\begin{array}{l}\text { HEU } \\
\text { Old ret } \\
\text { R4 }\end{array}$ & $\begin{array}{c}\text { HEU-233 } \\
\text { R5 }\end{array}$ \\
\hline \multicolumn{9}{|c|}{ Fuel elements (element/segment) } \\
\hline Makeup element & 1760 & 1322 & 661 & 980 & 1763 & 1763 & 500 & 245 \\
\hline 23R element & & & & 342 & & & 733 & 1642 \\
\hline $25 \mathrm{R}$ element & & & & & & & 89 & \\
\hline \multicolumn{9}{|l|}{ Other } \\
\hline Total & 1760 & 1322 & 661 & 1322 & 1763 & 1763 & 1322 & 1887 \\
\hline \multicolumn{9}{|c|}{ Heavy-element loadings (kg/element) } \\
\hline \multicolumn{9}{|l|}{ Makeup elements } \\
\hline Total uranium & 488 & 309 & 262 & 284 & 399 & & 074 & 056 \\
\hline${ }^{235} \mathrm{U}$ & 049 & 060 & 052 & 057 & & & 069 & 004 \\
\hline${ }^{233} \mathrm{U}$ & & & & & 047 & & & 040 \\
\hline Total plutonium & & & & & & 084 & & \\
\hline${ }^{239} \mathrm{Pu}+241 \mathrm{Pu}$ & & & & & & 058 & & \\
\hline Total thorium & & 249 & 35 & 411 & 714 & 459 & 1124 & 135 \\
\hline Total HM & 488 & 558 & 612 & 695 & 1113 & 543 & 1198 & 1406 \\
\hline \multicolumn{9}{|l|}{ 23R elements } \\
\hline Total uranium & & & & 446 & 399 & & 065 & 063 \\
\hline${ }^{233} \mathrm{U}$ & & & & 040 & 047 & & 049 & 040 \\
\hline${ }^{235} \mathrm{U}$ & & & & 027 & & & 003 & 005 \\
\hline Total thorium & & & & 411 & 714 & & 1124 & 135 \\
\hline Total HM & & & & 857 & 1113 & & 1189 & 1413 \\
\hline \multicolumn{9}{|l|}{$25 \mathrm{R}$ elements } \\
\hline $\begin{array}{l}\text { Total uranium } \\
235 \mathrm{U}\end{array}$ & & & & & & & $\begin{array}{l}124 \\
053\end{array}$ & \\
\hline Total thorium & & & & & & & 1124 & \\
\hline Total HM & & & & & & & 1248 & \\
\hline
\end{tabular}


Table 6. Average fresh fuel element description at equilibrium

\begin{tabular}{|c|c|c|c|c|c|c|c|c|}
\hline \multirow{2}{*}{ Characteristics } & \multicolumn{3}{|c|}{ Once-through cycles } & \multicolumn{5}{|c|}{ Recycle cycles } \\
\hline & $\begin{array}{l}\text { LEU } \\
\text { OT } 1\end{array}$ & $\begin{array}{l}\text { MEU-Th } \\
\text { dnnual } \\
\text { OT2 }\end{array}$ & $\begin{array}{l}\text { MEU-Th } \\
\text { semiannual } \\
\text { OT3 }\end{array}$ & $\begin{array}{c}\text { MEU-235 U/Th } \\
3 \mathrm{yI} \\
\mathrm{RI}\end{array}$ & $\begin{array}{c}M E U-{ }^{233} \mathrm{U} / \mathrm{Th} \\
3 \mathrm{yr} \\
\mathrm{R} 2\end{array}$ & $\begin{array}{l}\text { Pu/Th } \\
3 \text { yr } \\
\text { R3 }\end{array}$ & $\begin{array}{l}\text { HEU } \\
\text { Old ref } \\
\text { R4 }\end{array}$ & $\begin{array}{l}\text { HEU-233 } \\
\text { R5 }\end{array}$ \\
\hline \multicolumn{9}{|c|}{ Chemical composition-fuel kernels } \\
\hline $\begin{array}{l}\text { Makeup elements } \\
\text { 23R elements } \\
\text { 25R elements }\end{array}$ & $\mathrm{UC}_{2}$ (E-9\%-U5) & $\mathrm{UC}_{2}(\mathrm{E}-20 \%-\mathrm{U} 5)$ & $\mathrm{UC}_{2}(\mathrm{E}-20 \%-\mathrm{U} 5)$ & $\begin{array}{l}\mathrm{UC}_{2}(\mathrm{E}-20 \%-\mathrm{US}) \\
\mathrm{UC}_{2}(\mathrm{E}-60 \%-\mathrm{U} 3)\end{array}$ & $\begin{array}{l}\mathrm{UC}_{2}(\mathrm{E}-12 \%-\mathrm{U} 3) \\
\mathrm{UC}_{2}(\mathrm{E}-12 \%-\mathrm{U} 3)\end{array}$ & $\mathrm{PuO}_{1}(\mathrm{E}-70 \%-\mathrm{PI})^{c}$ & $\begin{array}{l}\mathrm{UC}_{2}(\mathrm{E}-93 \%-\mathrm{US}) \\
\text { UCO(E-80\%-UF) } \\
\text { UCO(E-43\%-US) }\end{array}$ & $\begin{array}{l}\mathrm{UC}_{2}(\mathrm{E}-78 \%-\mathrm{UI})^{b} \\
\mathrm{UC}_{2}(\mathrm{E}-72 \%-\mathrm{UI})\end{array}$ \\
\hline \multicolumn{9}{|l|}{ Fertıle } \\
\hline $\begin{array}{l}\text { Makeup elements } \\
\text { 23R elements } \\
\text { 25R elements }\end{array}$ & & $\mathrm{ThO}_{2}$ & $\mathrm{ThO}_{2}$ & $\begin{array}{l}(\mathrm{Th} / \mathrm{U}) \mathrm{O}_{2}(\mathrm{E}-20 \%-\mathrm{U} 5)^{a} \\
(\mathrm{Th}, \mathrm{U}) \mathrm{O}_{2}(\mathrm{E}-20 \%-\mathrm{U} 5)\end{array}$ & $\begin{array}{l}\mathrm{ThO}_{2} \\
\mathrm{ThO}_{2}\end{array}$ & $\begin{array}{l}\mathrm{ThO}_{2} \\
\mathrm{ThO}_{2}\end{array}$ & $\begin{array}{l}\mathrm{ThO}_{2} \\
\mathrm{ThO}_{2}\end{array}$ & $\begin{array}{l}\mathrm{ThO}_{2} \\
\mathrm{ThO}_{2}\end{array}$ \\
\hline \multicolumn{9}{|l|}{ Carbon ratios (per element) } \\
\hline \multicolumn{9}{|l|}{ Makeup elements } \\
\hline $\mathrm{C} / \mathrm{Th}$ & & 850 & 600 & 500 & 300 & 430 & 180 & 150 \\
\hline $\mathrm{C} / \mathrm{U}$ (or $\mathrm{C} / \mathrm{Pu})$ & 450 & 700 & 820 & 667 & 550 & 2500 & 2730 & 3250 \\
\hline $\mathrm{C} /$ heavy metal & 450 & 385 & 348 & 295 & 195 & 375 & 169 & 144 \\
\hline \multicolumn{9}{|l|}{$23 R$ elements } \\
\hline $\mathrm{C} / \mathrm{Th}$ & & & & 500 & 300 & & 180 & 150 \\
\hline $\mathrm{C} / \mathrm{U}$ & & & & 460 & 550 & & 3110 & 3250 \\
\hline C/heavy metal & & & & 240 & 195 & & 170 & 143 \\
\hline \multicolumn{9}{|l|}{$25 \mathrm{R}$ elements } \\
\hline $\mathrm{C} / \mathrm{Th}$ & & & & & & & 180 & \\
\hline $\mathrm{C} / \mathrm{U}$ & & & & & & & 1630 & \\
\hline $\mathrm{C} /$ heavy metal & & & & & & & 162 & \\
\hline \multicolumn{9}{|l|}{ Shipping requirements } \\
\hline Initial fuel elements & Unshielded & Unshielded & Unshelded & Unshielded & Shielded & Shrelded & Unsh relded & Shielded \\
\hline $\begin{array}{l}\text { Makeup elements } \\
\text { 23R elements }\end{array}$ & Unshielded & Unshielded & Unshelded & $\begin{array}{l}\text { Unshielded } \\
\text { Sh relded }\end{array}$ & Shielded & Shrelded & $\begin{array}{l}\text { Shelded } \\
\text { Shelded }\end{array}$ & Shrelded \\
\hline $25 \mathrm{R}$ elements & & & & & & & Shrelded & \\
\hline
\end{tabular}

${ }^{a} \mathrm{Th} / \mathrm{U}$ ratio $=375$

$b_{\mathrm{UF}}=$ fissle uranium $(235 \mathrm{U}+233 \mathrm{U})$

${ }^{c} \mathrm{PF}=$ fissile plutonium $\left({ }^{239} \mathrm{Pu}+{ }^{241} \mathrm{Pu}\right)$ 
Table 7. HTGR fuel cycles - equilıbrium discharge mass data

\begin{tabular}{|c|c|c|c|c|c|c|c|c|}
\hline \multirow{2}{*}{ I uel cycle discharge } & \multicolumn{3}{|c|}{ Once through - stowawdy cycles } & \multicolumn{5}{|c|}{ Recycle cases } \\
\hline & $\begin{array}{c}\text { LEU (10\% fissle) } \\
\left({ }^{235} \mathrm{U}\right)\end{array}$ & $\begin{array}{l}\text { MEU/Th (20\% fissule) } \\
{ }_{235}{ }^{35} \text { U (annual reload) }\end{array}$ & $\begin{array}{c}\text { MEU/Th (9\% fissle) } \\
2{ }_{2}{ }^{5} \mathrm{U} \text { (semiannual relodd) }\end{array}$ & $\begin{array}{c}\text { MEU/Th recy cle all uranium } \\
\text { dendture in stu } \\
2{ }^{235} \mathrm{U}\left(20 \% \text { fissile), }{ }^{23} \mathrm{U}(12 \% \text { fissile })\right.\end{array}$ & $\begin{array}{l}\text { MEU-233/Th } \\
{ }^{2{ }^{3} \mathrm{U} \text { makeup from breeder }} \\
{ }^{2{ }^{3} 3} \mathrm{U}(12 \% \text { fissile })\end{array}$ & $\begin{array}{c}\text { Pu/Th } \\
\text { Pu recycle }\end{array}$ & $\begin{array}{l}\mathrm{HEU} / \mathrm{Th} \text { recycle all }{ }^{233} \mathrm{U} \\
\quad \text { recycle }{ }^{23^{3}} \mathrm{U} \text { once }\end{array}$ & $\begin{array}{l}\text { HEU-233/Th } \\
\text { hugh conversion }\end{array}$ \\
\hline $\begin{array}{l}\text { Discharge interval } \\
\text { Cycle years }\end{array}$ & $\begin{array}{c}\text { Annual } \\
3\end{array}$ & $\begin{array}{c}\text { Annual } \\
4\end{array}$ & $\begin{array}{l}\text { Semi-dnnudl } \\
4\end{array}$ & $\begin{array}{c}\text { Annual } \\
4\end{array}$ & $\begin{array}{c}\text { Annual } \\
3\end{array}$ & $\begin{array}{c}\text { Annudl } \\
3\end{array}$ & $\begin{array}{c}\text { Annual } \\
4\end{array}$ & $\begin{array}{c}\text { Annual } \\
4\end{array}$ \\
\hline $\begin{array}{l}\text { No of fuel } \\
\text { elements in core }\end{array}$ & 5288 & 5288 & 5288 & 5288 & 5288 & 5288 & 5288 & 7548 \\
\hline rEs/discharge & 1763 & 1322 & 661 & 1322 & 1763 & 1763 & 1322 & 1887 \\
\hline $\begin{array}{l}\text { Reactor Power, } \\
\text { MW(e) }\end{array}$ & $1360(1332$ net $)$ & $1360(1332$ net $)$ & 1360 (1332 net) & 1360 (1332 net) & 1360 (1332 net) & 1360 (1332 net $)$ & 1360 (1332 net) & 1360 (1332 net) \\
\hline Total HM, kg & 7539 & 6474 & 3628 & 8770 & 18,583 & & 15,126 & \\
\hline Th, $\mathrm{kg}$ & 0 & 3040 & 2115 & 5050 & 12,587 & 7898 & 14,370 & 24,512 \\
\hline $\mathrm{U}-233, \mathrm{~kg}$ & & 93 & 59 & 145 & 458 & 705 & 409 & 698 \\
\hline $\mathrm{U}-235, \mathrm{~kg}$ & 88 & 79 & 21 & 66 & 244 & 53 & 112 & 111 \\
\hline Total U, kg & 7439 & 3345 & 1475 & 3647 & 6427 & 102 & 826 & 1208 \\
\hline Fissile $\mathbf{P u}, \mathrm{kg}$ & 411 & 47 & 18 & 38 & 30 & 268 & 18 & 04 \\
\hline $\begin{array}{l}\text { Total } \mathrm{Pu}, \mathrm{kg} \\
\text { Enriched fissle } \\
\text { production, } \mathrm{kg}\end{array}$ & 1003 & 90 & 38 & 73 & 60 & 504 & 77 & 44 \\
\hline $\mathrm{Pu}$ & $\begin{array}{c}100 \\
(41 \% \mathrm{E})\end{array}$ & $\begin{array}{c}90 \\
(53 \% \mathrm{E})\end{array}$ & $\begin{array}{c}38 \\
(467 \% \mathrm{E})\end{array}$ & $\begin{array}{c}73 \\
(52 \% E)\end{array}$ & $\begin{array}{c}60 \\
(50 \% \leftarrow)\end{array}$ & $\begin{array}{c}504 \\
(53 \% \mathrm{E})\end{array}$ & $\begin{array}{r}77 \\
(238 \% E)\end{array}$ & $\begin{array}{r}44 \\
(10 \% \mathrm{E})\end{array}$ \\
\hline $\mathrm{u}$ & $\begin{array}{l}>439 \\
(118 \% \mathrm{E})\end{array}$ & $\begin{array}{c}3128 \\
(551 \% \mathrm{E})\end{array}$ & $\begin{array}{l}1475 \\
(55 \% \mathrm{E})\end{array}$ & $\begin{array}{l}3647 \\
(58 \% \mathrm{E})\end{array}$ & $\begin{array}{c}6427 \\
(751 \% \mathrm{E})\end{array}$ & $\begin{array}{c}102 \\
(741 \% \mathrm{E})\end{array}$ & $\begin{array}{c}692 \\
(70 \% \mathrm{E})\end{array}$ & $\begin{array}{l}1208 \\
(67 \% \mathrm{E})\end{array}$ \\
\hline
\end{tabular}




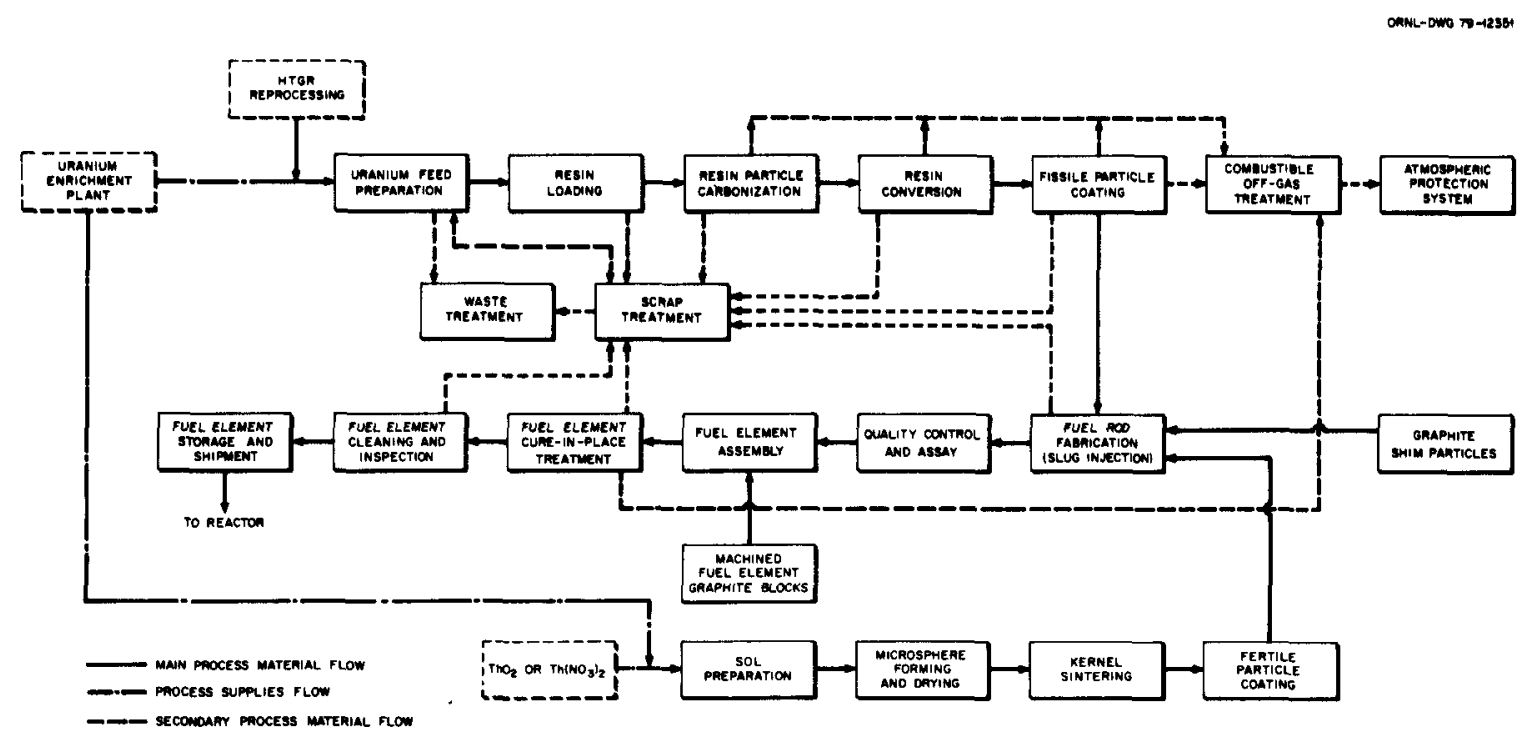

Fig. 13. Simplified HTGR fuel refabrication process flowsheet.

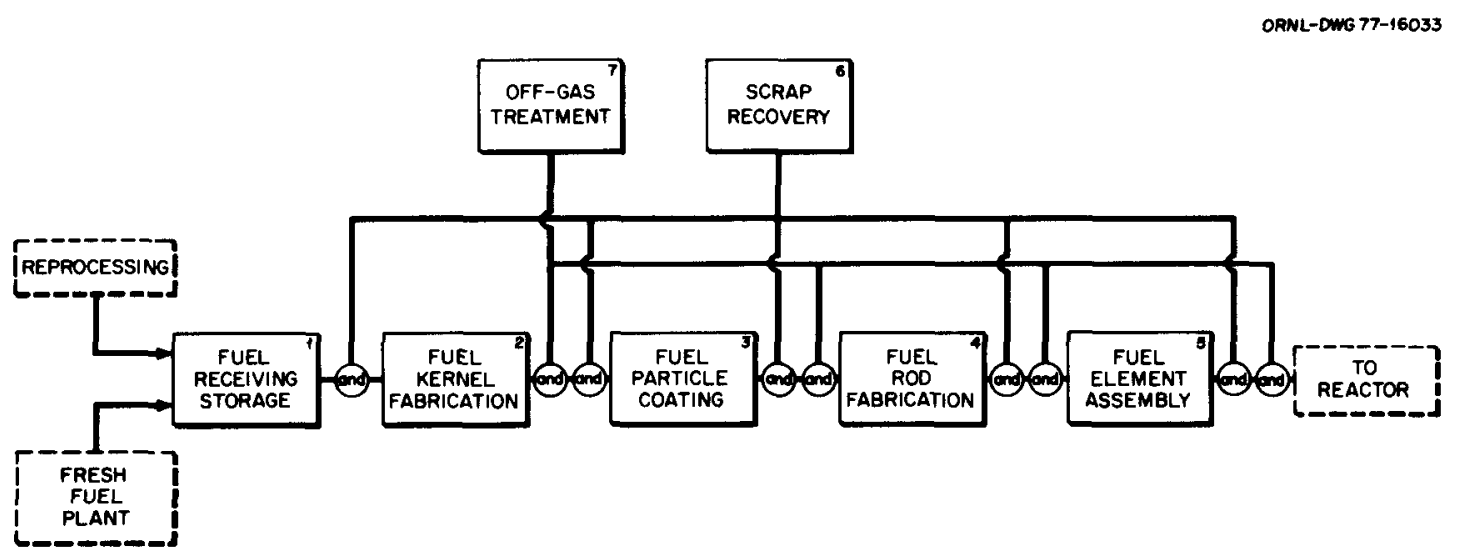

Fig. 14. Functional flow diagram for HTGR fuel element fabrication-refabrication.

this analysis, some uranium may be received as fully coated microspheres from a fabrication plant requiring no processing before the fuel rod fabrication step, or uranium may be received as medium-enriched $\mathrm{UF}_{6}$ or as depleted $\mathrm{UO}_{2}$. For the one case where plutonium is the fissile material, it would be received as $\mathrm{PuO}_{2}$.

Thorium can be received in a variety of forms: as thorium nitrate solution from the reprocessing plant; as $\mathrm{ThO}_{2}$ or $\mathrm{Th}\left(\mathrm{NO}_{3}\right)_{4}$ from commercial suppliers; or, in certain refabrication cases, as fully coated microspheres from a fabrication plant. These materials are stored in appropriate containers in a safeguarded manner and provide the feed to the fuel kernel fabrication processes.

\subsubsection{Fuel kernel fabrication}

The primary process variations in the fabrication and refabrication of the fuel for the various fuel cycles are concentrated in this functional area. Because of reactor physics considerations and fuel performance characteristics, different types of fissile particles are required for the various fuel cycles. The product of 
fuel kernel fabrication is uniformly sized oxide particles or oxide containing some carbide. The two basic processes for making these kernels are the weak-acid resin process and the gel precipitation process. The first method involves the loading of uranium on presized ion exchange resin microspheres and their subsequent fluidized-bed conversion to a relatively low-density kernel containing $\mathrm{UO}_{2}+\mathrm{UC}_{2}$ and some excess carbon. The gel precipitation process prepares solid-gel spherical particles directly from an aqueous solution of the metal nitrates to which a gelling agent has been added. The gel particles are sintered to form the high-density metal oxide or mixed metal oxide-carbide fissile kernel. This process is used for fissile kernels containing plutonium, denatured uranium, or blended uranium and thorium. Formation of the dried gel particle may be done at the conversion process in a reprocessing plant.

The fertile particles are also prepared by two processes, and the product is always a high-density microsphere of the metal oxide $\left(\mathrm{ThO}_{2}\right)$ or of the mixed metal oxide $(\mathrm{U}, \mathrm{Th}) \mathrm{O}_{2}$. The $(\mathrm{U}, \mathrm{Th}) \mathrm{O}_{2}$ particles contain $20 \%$ enrichment uranium; however, they are referred to as fertile particles because of the predominance of fertile thorium. Pure $\mathrm{ThO}_{2}$ fertile kernels are typically prepared by the well-established sol-gel process in which a thorium nitrate solution is denitrated by steam to yield an aqueous sol containing suspended $\mathrm{ThO}_{2}$. The resulting sol is transformed into microspheres by passing the sol through a vibrating nozzle into a drying solvent. These gel microspheres are sintered to produce the dense $\mathrm{ThO}_{2}$ fertile kernels. When in situ denaturing of the ${ }^{233} \mathrm{U}$ bred from the thorium is required for the cycle, the solid gel

microspheres are formed directly from a blend made by mixing a uranyl nitrate solution (20\% enriched uranium) with a thorium nitrate solution to which a gelling agent has been added. Spheres are formed by passing the solution through a vibrating nozzle. The gellation is induced by the heated organic receiving bath. These gel microspheres are also washed and sintered to produce the dense $(\mathrm{U}, \mathrm{Th}) \mathrm{O}_{2}$ fertile kernel microspheres.

All fuel kernels undergo a number of quality control inspections such as size, shape, and integrity. Reject material is sent to scrap recovery, and acceptable kernels are sent to fuel particle coating.

\subsubsection{Fuel particle coating}

The fuel kernels in both fabrication and refabrication are coated in fluidized-bed coaters. The appropriate hydrocarbon or silane gases are introduced into the fluidized gas stream and thermally decomposed to provide the appropriate coating material. Two types of coatings are applied. The fissile particles are provided with a TRISO coating which consists of an inner low-density carbon layer (buffer), a high-density isotropic carbon layer (inner low-temperature isotropic, ILTI), a high-density silicon carbide (SiC) layer, and an outermost layer of high-density carbon (outer low-temperature isotropic, OLTI). The fertile particles typically have only a two-layer BISO coating consisting of the low-density carbon buffer adjacent to the kernel covered with a relatively thick high-density isotropic carbon layer.

These coatings provide for fission product retention and so must be impermeable to the fission products. Thus, all coated particles experience a high level of quality control, and only acceptable coated particles are forwarded to the fuel rod fabrication process. Reject material is sent to scrap recovery.

\subsubsection{Fuel rod fabrication}

Individual fuel rods are made up by dispensing controlled quantities of fissile and fertile coated particles, together with inert graphite particles, used to permit loading variations to adjust for reactor zoning requirements, into a blender, and the homogeneous mixture is poured into a die to form a packed bed. The bed is intruded with a carbonaceous binder, and the resulting green fuel rod is ejected from the mold. Each fuel rod undergoes a series of quality control inspections, including dimensional verification, homogeneity 
analysis, and a heavy-element assay. Acceptable rods are placed in protective racks for transfer to fuel element assembly, and reject rods are sent to scrap recovery.

\subsubsection{Fuel element assembly}

In fuel element assembly, the green fuel rods, together with appropriate burnable poison disks, are assembled into fuel columns and inserted into machined graphite blocks. Each fuel column is capped by a graphite plug. The entire assembly is then transferred to a high-temperature furnace and heated in a controlled time and temperature treatment cycle to remove the volatile components of the green fuel rod binder and convert the residue to carbon. The resulting integral fuel element is cleaned, inspected, and packaged for shipment to the reactor.

\subsubsection{Off-gas treatment}

Each of the major process steps, including scrap recovery, produces gaseous waste products which must be treated before release to the atmosphere. All gaseous streams receive high-efficiency filtration to prevent release of even minor quantities of particulate material. Chemical operations in the fuel kernel fabrication processes are vented through systems to remove the nitrogen oxides and, in the case of refabrication involving ${ }^{233} \mathrm{U}$ and recycle thorium, to trap the short-lived ${ }^{220} \mathrm{Rn}$ and other daughter products from the

${ }^{232} \mathrm{U}$ decay process. Special scrubbers are used in the off-gas streams from the fuel particle coating and fuel element assembly furnaces to remove the volatile components of the green fuel rod binder and convert the residue to carbon. The resulting integral fuel element is cleaned, inspected, and packaged for shipment to the reactor.

\subsubsection{Scrap recovery}

As indicated in the descriptions of the various fabrication processes, the high-quality control standards result in the rejection of significant quantities of off-specification material. Scrap recovery is, therefore, an integral part of both a fabrication and a refabrication process. The scrap recovery processes are subdivided to meet the requirements imposed by the form of the source material and include: controlled burning to remove the carbon, crushing for silicon carbide-coated particles, separation of fissile from fertile particles, dissolution of burner ash, and one stage of solvent extraction to remove any contaminants picked up in the processes from the recovered heavy-metal nitrate solutions before they are recycled. With scrap recovery, total fuel material losses in refabrication are anticipated to be less than $1 \%$.

\section{COST ESTIMATION PROCEDURES}

The base case for metal-clad fuels was the study of a pressurized water reactor reported in ORNL/TM-6501. ${ }^{1}$ That report provided a somewhat detailed analysis of the facility, equipment, and operating requirements for the fabrication of fuel for current-design PWRs. Capital and operating costs were estimated for a plant with a 2-MT HM/d capacity.

To relate other metal-clad fuels (including other PWR cases) to this base case, a direct comparison was made of fuel fabrication functions required for each fuel type. This was a systematic procedure in which the functional flowsheets for fabrication of the various fuels were compared with the reference PWR fuel fabrication flowsheet, and appropriate additions or deletions were made. Note that the determination of requirements for each case is based on fabrication of specific fuel assemblies previously described in this 
report. Capacity requirements for the various functions were assessed based on the designs of the fuel assemblies (number of fuel rods in each assembly, number of pellets in a fuel rod, etc.) and used in the following cost categories:

1. capital cost of facility,

2. capital cost of equipment,

3. annual material costs,

4. annual operating costs.

The procedure for relating estimates of any fuel type to the reference PWR case was similar for each capital-cost category. As an example, consider the facility capital-cost category. In ORNL/TM-6501, estimates were made of area requirements for the various process functions, and the costs associated with these portions of the facility were determined by multiplying the area by a unit area cost of $\$ 200 / \mathrm{ft}^{2}$ (except the quality-control laboratories, for which a unit cost of $\$ 400 / \mathrm{ft}^{2}$ was used). The area requirements for other metal-clad fuels were estimated by comparing the area requirements for specific fuel fabrication functions with those of the reference case. This comparison was accomplished by the assignment of incremental multipliers to the areas. For example, if, in our estimation, approximately $30 \%$ more area than that required for pelleting PWR $\left({ }^{255} \mathrm{U}, \mathrm{U}\right) \mathrm{O}_{2}$ fuel were required for one of the other candidate fuels, the incremental multiplier for the pelletization area would be 1.3. Impacts on area requirements of process complexity, atmosphere requirements, capacity requirements, remote operation, shielding, and maintenance were assessed to enable us to assign reasonable values to the incremental multipliers. After the estimates of functional area requirements were made, the total process area was determined by summation of individual process areas. Equations were developed to relate support areas to total process areas. Unit area costs were assigned to the process and support areas, and total costs were determined as the product of area times unit area cost. A summary of the factors used in the estimation of area costs and the equations that relate support areas to process areas are presented in Table 8. In those instances where similar functions did not exist in the base case (such as wire wrapping of FBR fuel rods), estimates of added space for these operations were made.

This procedure was repeated for the capital-cost (facility and equipment) categories for all metal-clad fuels. Consideration was given in all instances to effects due to such things as process complexity, criticality considerations, and personnel exposure limitations. We believe this approach provides consistency in the evaluation of the different fuels and also provides accuracy in the determination of relative costs of the different fuels. Hardware costs were based on independent estimates of costs by suppliers or buyers of the hardware. These hardware costs were independently estimated for each fuel type.

Since HTGR fuel elements are fabricated by distinctly different processes, it was necessary to establish a new reference for estimating the cost of fabricating these fuels. Fortunately, there were available specific estimates based on conceptual designs of fuel-cycle plants for HTGR fuels utilizing highly enriched uranium with self-generated recycle. General Atomic had developed a conceptual design and cost estimate with the assistance of the R. M. Parsons Company in $1975,{ }^{2}$ and this was reviewed, revised, and updated as part of the commercialization study done by the R. A. McCormick Company (RAMCO) for the DOE in $1977 .{ }^{12}$ The reference case cost estimates were derived from this latter study.

To provide consistency and minimize variables in estimating costs, certain facility design assumptions were adopted; they are summarized in Table 9.

As may be noted by reference to Table 9, our assumption was that reference plant capacities were $2 \mathrm{MT}$ $\mathrm{HM} / \mathrm{d}$. Because of the heavy-metal loading of different fuel assemblies and differences in fuel management 
Table 8. Factors used for fuel fabrication cost estimates

\begin{tabular}{|c|c|c|c|c|c|c|}
\hline \multirow{3}{*}{ Equations ${ }^{a}$} & \multicolumn{6}{|c|}{ Unit area cost $\left(\$ / \mathrm{ft}^{2}\right)$} \\
\hline & \multicolumn{2}{|c|}{ Contact } & \multicolumn{2}{|c|}{$\mathrm{RO} / \mathrm{CM}$} & \multicolumn{2}{|c|}{ RO/RM } \\
\hline & Oxides & $\begin{array}{l}\text { Carbides } \\
\text { or metals }\end{array}$ & Oxides & $\begin{array}{l}\text { Carbides } \\
\text { or metals }\end{array}$ & Oxides & $\begin{array}{l}\text { Carbides } \\
\text { or metals }\end{array}$ \\
\hline$A_{X}=(f)\left(A_{0}\right)$ (contact facility) & 200 & 300 & & & & \\
\hline$A_{X}=(f)\left(A_{0}\right)(1.3)(R O / C M$ or $R O / R M$ facility $)$ & & & 1000 & 1250 & 1200 & 1500 \\
\hline$A_{Y}=(0.5)\left(A_{X}\right)$ & 200 & 200 & 200 & 200 & 200 & 200 \\
\hline $\mathbf{A}_{\mathrm{RM}}=\mathbf{A}_{\mathrm{X}}$ & & & & & 1200 & 1200 \\
\hline $\mathrm{A}_{\mathrm{CM} / \mathrm{R}}=(0.05)\left(\mathrm{A}_{\mathrm{RM}}\right)$ & & & & & 400 & 400 \\
\hline$A_{C M}=(0.5)\left(A_{X}\right)$ & 200 & 200 & 400 & 400 & & \\
\hline$A_{F S}=(0.2)\left(A_{X}+A_{Y}+A_{R M}+A_{C M}\right)$ & 200 & 200 & 200 & 200 & 200 & 200 \\
\hline$A_{Q C}=(f)\left(A_{Q C_{0}}\right)(1.3)$ & & & 1000 & 1000 & 1000 & 1000 \\
\hline$A_{Q C}=(f)\left(A_{Q_{0}}\right)$ & 400 & 400 & & & & \\
\hline$A_{W H}=(1.3)\left(A_{W H_{o}}\right)$ & & & 100 & 100 & 100 & 100 \\
\hline$A_{W H}=A_{W_{0}}$ & 200 & 200 & & & & \\
\hline $\begin{array}{l}A_{C H}=(f)\left(A_{C_{H}}\right) \\
E_{F}=\Sigma E_{0}\left(f^{\prime}\right)\end{array}$ & 200 & 200 & 200 & 200 & 200 & 200 \\
\hline
\end{tabular}

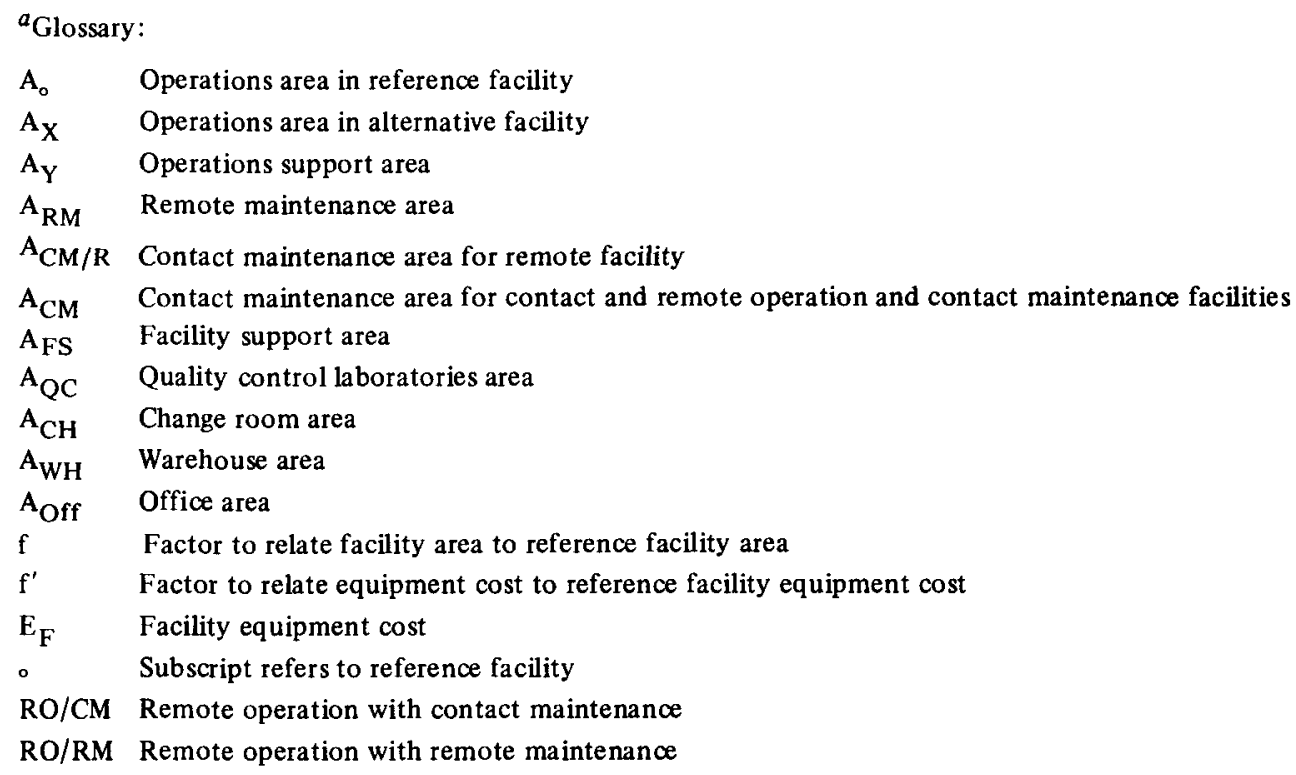

schemes, the reference plants provide a wide range of electrical industry support. However, costs may be reduced to the basis of electrical power support by the use of scaling factors, which are subsequently presented in this report.

The following sections present tabular summaries of the cost estimates for the various fuels and reactor types.

\subsection{Cost Estimates for PWR (or SSCR) Fuel Fabrication}

The PWR fuels, and all metal-clad fuels, were based on a reference PWR case reported previously. ${ }^{1}$ The basic processing and support operations were defined for this case and were extended to the other cases. 
Table 9. Fuel fabrication and refabrication facility design assumptions

\begin{tabular}{|c|c|}
\hline Fuel materials & $\mathrm{U}, \mathrm{Pu}$, and $\mathrm{Th}$ oxides, carbides, oxycarbides, and metals \\
\hline Modes of operation & $\begin{array}{l}\text { Contact (hooded); remote operation with contact maintenance (RO/CM); remote } \\
\text { operation with remote maintenance (RO/RM) }\end{array}$ \\
\hline Production capacities & $\begin{array}{l}520 \mathrm{MT} \mathrm{HM} / \text { year (contact facilities) }{ }^{a} 480 \mathrm{MT} \mathrm{HM} / \mathrm{year} \text { (RO/CM and RO/RM } \\
\text { facilities) }^{a}\end{array}$ \\
\hline Design capacity $b$ & $\begin{array}{l}243 \mathrm{MT} \mathrm{HM} / \text { year per fuel rod production line; } 730 \mathrm{MT} \mathrm{HM} / \text { year fuel assembly } \\
\text { operations }\end{array}$ \\
\hline Plant efficiencies & $72 \%$ (contact facilities); $67 \%$ (RO/CM and RO/RM facilities) \\
\hline $\begin{array}{l}\text { Plant operating factors, } \% \text { of } \\
\text { full-production capacity }\end{array}$ & $\begin{array}{lr}\text { First year } & 33 \\
\text { Second year } & 67 \\
\text { Third and subsequent years } & 100\end{array}$ \\
\hline Operating philosophy & $\begin{array}{l}24 \mathrm{hr} / \text { day, } 7 \text { days/week. Certain activities may be curtailed or reduced on some } \\
\text { shifts, but operating personnel will be at plants } 24 \mathrm{hr} / \text { day. }\end{array}$ \\
\hline Principle of operation & $\begin{array}{l}\text { Toll processing. Sufficient feed material provided by customer to fabricate fuel } \\
\text { with a specified yield. All materials other than heavy-metal feed are provided by } \\
\text { fuel fabricator. }\end{array}$ \\
\hline $\begin{array}{l}\text { Feed materials (from reprocessing } \\
\text { as calcined powder or microspheres) }\end{array}$ & $\begin{array}{l}\text { Oxide fuels - heavy-metal oxides; carbide fuels - heavy-metal oxides; oxycarbide } \\
\text { fuels - heavy-metal oxides; metal fuels - heavy-metal fluorides }\end{array}$ \\
\hline Hardware production & $\begin{array}{l}\text { Basic hardware items or stock materials are purchased. Incorporation of items } \\
\text { into finished units is performed at fuel fabrication facility. Axial blanket material } \\
\text { for FBRs is purchased as sintered pellets; cost of axial blanket material is proces- } \\
\text { sing cost only, i.e., customer provides all feed material. }\end{array}$ \\
\hline Waste treatment & $\begin{array}{l}\text { All wastes are prepared and packaged for disposal as immobile solids. Transporta- } \\
\text { tion and ultimate disposal of wastes are not provided. }\end{array}$ \\
\hline Scrap recycle & All clean and dirty scrap is recycled within the fuel fabrication plant. \\
\hline Feed shipments & $\begin{array}{l}\text { Feed materials are provided by customer, FOB the fabrication plant in customer- } \\
\text { owned containers. }\end{array}$ \\
\hline Product shipments & $\begin{array}{l}\text { Finished fuel assemblies are packaged in plant operator-owned shipping containers } \\
\text { or casks. Transportation of fuel assemblies to reactor sites is the responsibility of } \\
\text { the customer. }\end{array}$ \\
\hline
\end{tabular}

${ }^{a}$ Capacities given in terms of total heavy metal as finished fuel assemblies. For FBR fuels, this includes core plus axial blanket material.

${ }^{b}$ Design capacity means the capability of the plant in MT HM/year when it operates as described under operating philosophy with each shift operating at $100 \%$ efficiency. Production capacities are determined by multiplying design capacity by efficiencies. Efficiencies account for unscheduled (maintenance problems, etc.) and scheduled (vacation, holidays, etc.) operating interruptions.

The detailed review of this reference case was the basis for definitions of processing and support functions presented in Table 8. We note that for the reference PWR case $-\left({ }^{235} \mathrm{U}, \mathrm{U}\right) \mathrm{O}_{2}$ fuel - and for the $\left({ }^{235} \mathrm{U}, \mathrm{Th}\right) \mathrm{O}_{2}$-fueled PWR, the equations presented in Table 6 were not used. That is, for these two cases an analysis of all processing and support functions was made to establish requirements and costs. Also, for the contact-operated and -maintained HWR cases and the $\left({ }^{235} \mathrm{U}, \mathrm{Th}\right) \mathrm{O}_{2}-\mathrm{ThO}_{2}$ LMFBR core case, fuel maintenance space requirements were based on estimates rather than the formula in Table 8. For all other 
metal-clad cases, the equations presented in Table 8 were used. For the $\left({ }^{235} \mathrm{U}, \mathrm{U}\right) \mathrm{O}_{2}$ and $\left({ }^{255} \mathrm{U}, \mathrm{Th}\right) \mathrm{O}_{2}$ PWR cases, additions of $30 \%$ (for engineering and contingencies) were made to the estimated facility costs. This addition was not made for the other cases, because these costs were reflected in the incremental multipliers assigned and in the unit area costs.

\subsubsection{Facility capital costs}

As stated earlier, facility costs were determined by obtaining estimates of processing area requirements and then assigning unit area costs, depending on the nature of the process functions. The unit area costs are presented in Table 8 for the various processing modes - contact, remote operation with contact maintenance, and remote operation with remote maintenance. As may be observed from the entries in Table 8, the complexity of the processing mode and the requirements for special processing atmospheres (for carbide and metal fuels) reflect directly on the unit area costs.

In Table A-1* we have summarized our estimates of the area required for the various process functions for PWR fuel fabrication. Table A-2 presents the conversion of these area estimates to costs, and also includes the costs of the various support areas determined by application of the equations of Table 8 .

\subsubsection{Equipment capital costs}

Equipment cost estimates for PWR fuel fabrication facilities are presented in Table A-3. For all cases except the $\left({ }^{235} \mathrm{U}, \mathrm{U}\right) \mathrm{O}_{2}$ and $\left({ }^{235} \mathrm{U}, \mathrm{Th}\right) \mathrm{O}_{2}$ fuels, the technique for determining equipment costs was the same - the process functions were compared with the reference case, incremental multipliers were assigned based on increased or decreased equipment requirements, and equipment costs were calculated for each process area.

\subsubsection{Operating costs}

Operating cost categories generally include labor and supervision, overhead, general and administrative, materials, and utilities. Because of the appreciable impact of hardware and material costs on overall fuel fabrication costs, we separated the costs of materials from operating costs and created an operating cost category and a materials cost category.

The organizational structure developed for the reference PWR case was considered appropriate for all facilities. In order to determine personnel costs, we made an assessment of increased, or decreased, personnel requirements for all plants when compared with the reference plant. This assessment was made for each organizational unit. The incremental cost increases, or decreases, were determined, and total personnel costs were determined by adding these incremental costs to the reference case. For clarification, the organization chart developed for the reference case is presented in Fig. 15. This chart identifies the various organizational units that we considered necessary to operate a fuel fabrication or refabrication facility.

The costs of utilities were estimated from requirements dictated by the number of personnel, the equipment used in the various fabrication operations, and the amount of material produced.

Overhead and general and administrative costs include management personnel costs, travel, telephone, office supplies, postage, professional and legal fees, and miscellaneous fees, assessments, contributions, memberships, and subscriptions. Most of this cost is directly related to the number of personnel required to operate the facility. Operating cost summaries for the PWR fuel cycles are presented in Table A-4.

*Tables A-1 to A-25 are presented in Appendix A. 
ORNL-DWG 78-10930

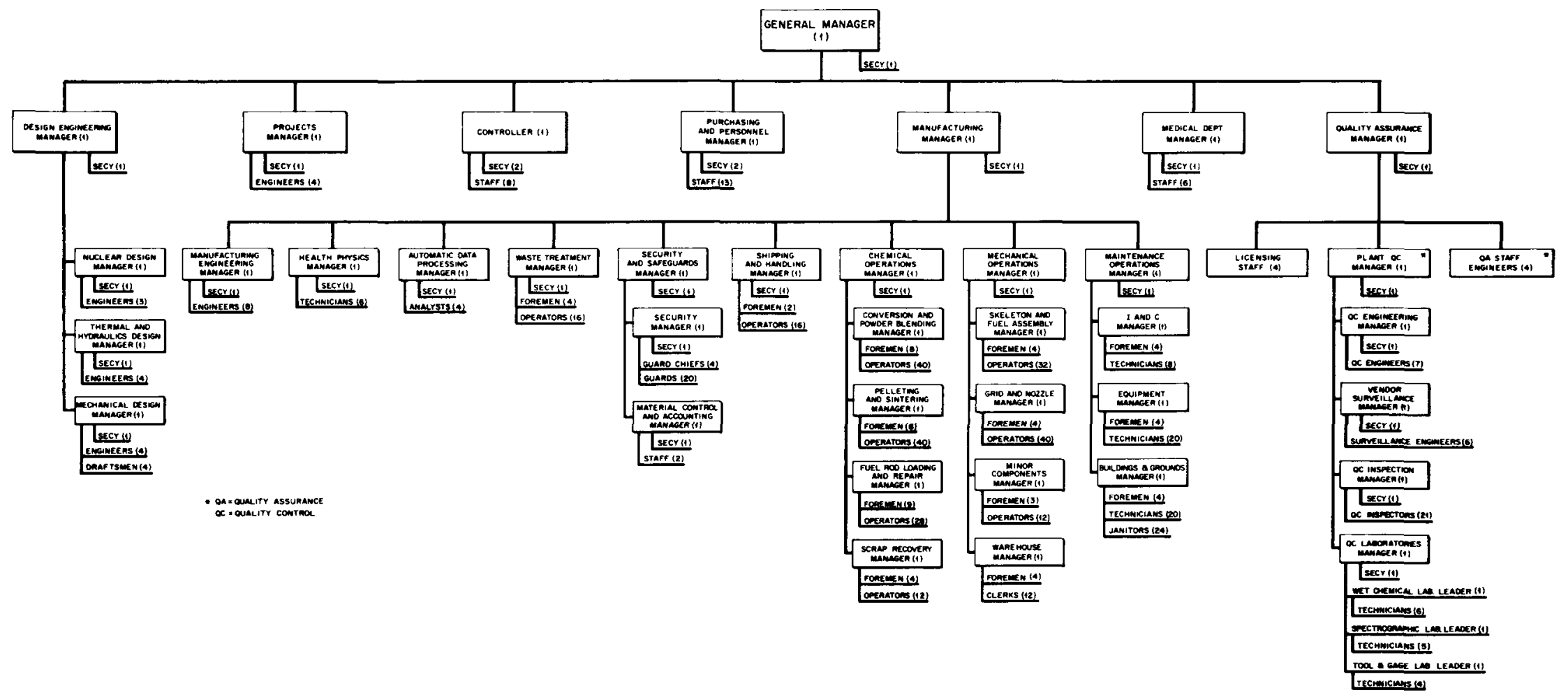

Fig. 15. Organization chart for a 2-MT HM/d PWR fuel fabrication plant. 


\subsubsection{Materials}

The materials cost category includes direct materials - those materials actually used in processing the fuel, indirect materials such as waste-processing chemicals, supplies such as containers, and fuel assembly hardware. Of these, fuel assembly hardware makes the most significant impact on cost. Hardware costs and material costs are based on estimates by suppliers or on information contained in trade journals. Materials costs for PWR fuels are summarized in Table A-5.

\subsection{Cost Estimates for HWR Fuel Fabrication}

The basic operations for fabrication of HWR fuel are similar to those used for PWR fuel fabrication. The HWR fuel assembly design is somewhat simpler than that for the PWR, and this is reflected in lower costs of the fuel assembly fabrication operations.

\subsubsection{Facility capital costs}

The space requirements for the functional areas of the HWR fuel fabrication plant are presented in Table A-6, and the capital costs of the facility are summarized in Table A-7. These areas and costs were determined by the same technique used for the PWR fuel fabrication facilities.

\subsubsection{Equipment capital costs}

The capital costs for HWR fuel fabrication equipment are summarized in Table A-8.

\subsubsection{Operating costs}

The estimated costs of operating HWR fuel fabrication plants are presented in Table A-9.

\subsubsection{Materials}

Materials requirements, except for hardware, are about the same for HWR fuel fabrication as for PWR fuel fabrication. Due to the simplicity of the CANDU fuel assembly design, hardware does not represent as significant a contribution to material costs as it did for PWR fuels. Table A-10 presents the material cost estimates for HWR fuel fabrication.

\subsection{Cost Estimates for LMFBR Fuel Fabrication}

The cost estimation procedure for LMFBR fuel was the same as that described for the other metal-clad fuels. Some complications are introduced due to the increased complexity of the fuel assembly design, problems associated with handling the carbide and metal fuels, and the difficulty of handling metallic sodium. The impact of these complications on fuel fabrication costs is reflected by additional operations and increased unit area costs.

\subsubsection{Facility capital costs}

Area requirements and facility capital costs for LMFBR oxide fuel fabrication are presented in Tables A-1 1 and A-12 respectively. Similar information is provided for LMFBR carbide fuels by Tables A-16 and A-17, and for LMFBR metal fuels by Tables A-21 and A-22. 


\subsubsection{Equipment capital costs}

Capital cost estimates for equipment for LMFBR oxide, carbide, and metal fuels are presented in Tables A-13, A-18, and A-23 respectively.

\subsubsection{Operating costs}

Operating cost summaries for LMFBR oxide, carbide, and metal fuels are shown in Tables A-14, A-19, and $\mathrm{A}-24$ respectively.

\subsubsection{Materials}

Tables A-15, A-20, and A-25 provide material cost information for LMFBR oxide, carbide, and metal fuels respectively.

\subsection{Cost Estimates for HTGR Fuel Fabrication}

As stated earlier, the estimated costs for fabrication of HTGR fuels are primarily based on the commercialization study performed by RAMCO for the DOE in 1977. The following sections describe the techniques used to extend this information to the cases of interest.

\subsubsection{Capital cost estimates}

The reference case capital cost estimates were derived by making only moderate modifications to the data in the commercialization study. The modifications included a change in estimates to 1978 dollars, minor adjustments to the reference plant capacities defined for this study (see Table 7), and adjustments to define the refabrication plant as a stand-alone facility. This last adjustment was necessary because the commercialization study assumed the calculation of a reprocessing and refabrication plant, while this study assumed separate plants as with the metal-clad fuels discussed in Sect. 3.1.

The resulting reference case capital costs thus derived are summarized as follows in 1978 dollars:

$\begin{array}{cc}\text { Fabrication plant } & (520 \text { MT HM/yr }) \\ \text { Facility } & 51 \text { million } \\ \text { Equipment } & 166 \text { million } \\ & \\ \text { Refabrication plant } & (480 \mathrm{MT} \mathrm{HM} / \mathrm{yr}) \\ \text { Facility } & 304 \text { million } \\ \text { Equipment } & 498 \text { million }\end{array}$

The refabrication plant cost estimates include stand-alone additions of $\$ 14$ million in the facility portion and $\$ 35$ million in the equipment portion. Because of the conceptual design limitations for these facilities, a contingency of $35 \%$ was used. This provides consistent estimates with the metal-clad fuels estimates.

The alternative fuel-cycle capital cost estimates were derived, as with the metal-clad fuels, by evaluating each fuel element design, defining the process flowsheets, and evaluating the capacity requirements for the process functional areas. It should be noted that the HTGR fabrication costs are very sensitive to fuel element design characteristics. Consequently, a specific procedure was developed to scale the capital cost estimates from the reference design to the alternative cases. 
First, an evaluation was made of the facility costs in terms of capacity requirements. It was found that the facility space was directly proportional to the number of fuel elements produced to achieve the required annual heavy-metal throughput. Thus the facility capacity ratio is readily defined:

$$
\frac{x_{u}}{x_{0}}=\text { capacity ratio, }
$$

where

$x_{u}=$ fuel elements per year produced in the plant being evaluated,

$x_{0}=$ fuel elements per year produced in the reference plant.

On the other hand, the equipment capacity ratios are more complex and are derived differently for fabrication plants and refabrication plants. The complexity derives in part from the fact that the total heavy-metal fuel throughput is made up of two types of particles.

The fissile particles contain ${ }^{235} \mathrm{U},{ }^{233} \mathrm{U}$, and/or Pu. Fissile particle processing is more complicated than the fertile particle processing, in part because the coating includes an intermediate layer of silicon carbide. Equipment capacities are smaller because of criticality restraints. Batch-type operations are required and batch sizes are small. This batch type of operation requires considerable inspection equipment, as well as blending and storage equipment to create practical production lot sizes.

The fertile particles in most cases contain only thoria. The coating is simpler and can be applied much more rapidly. There are no criticality restraints, so batch sizes are roughly three times as large as fissile particles in the coating furnaces. Other processing is adaptable to continuous rather than batch operation. In one of the cases included in this study (MEU/Th, designated R1) the fertile particles are a blend of uranium and thorium with fissile ${ }^{235} \mathrm{U}$ in the uranium. This necessitates an adjustment in the fissile and fertile distributions in the cost estimation procedure.

A second effect of the use of two particles defines a difference between fabrication and refabrication plants. Both fissile and fertile coated particles are produced in a fabrication plant, while only fissile particles are prepared and coated in a refabrication plant.

Once satisfactory coated fissile and fertile products are available, the equipment requirements for fabricating fuel rods and incorporating them into finished fuel elements are directly proportional to the number of fuel elements produced per year.

To assess the capacity ratios of equipment requirements for alternate fuel cycles, it was necessary to define the fraction of the equipment associated with particle preparation. This was done with a functionby-function cost analysis of the data available for the reference case. Analysis showed that approximately $20 \%$ of the total equipment cost was associated with coated particle preparation. With this information the following formulations were used to define equipment capacity ratios.

1. For fabrication plants

$$
\frac{x_{u}}{x_{0}}=\frac{(\mathrm{kgU}+\mathrm{kgTh} / 3)_{\mathrm{u}}}{(\mathrm{kgU}+\mathrm{kgTh} / 3)_{0}} \times 0.2+\frac{(\text { fuel elements per year })_{\mathrm{u}}}{(\text { fuel elements per year })_{0}} \times 0.8
$$

2. For refabrication plants

$$
\frac{x_{u}}{x_{0}}=\frac{(\mathrm{kg} \text { of heavy metal in fissile })_{\mathrm{u}}}{(\mathrm{kg} \text { of heavy metal in fissile })_{0}} \times 0.2+\frac{(\text { fuel elements per year })_{\mathrm{u}}}{(\text { fuel elements per year })_{0}} \times 0.8
$$


In both sets, $x_{0}$ is the capacity of the reference plant of the type being estimated, and $x_{u}$ is the capacity of the alternative fuel-cycle plant. In the equations above, the capacities for the coated particle preparation equipment are about three times greater for thorium because of the lack of criticality restrictions. For refabrication, only fissile particles are fabricated remotely.

Having established capacity ratios for the two portions of the capital cost estimate increments (facility and equipment), it was necessary to determine the effect of the changes in capacity on cost estimates. This was done by application of plant capacity scaling factors. These capacity scaling factors apply to metal-clad fuels as well as to HTGR fuels, and their derivations are discussed in Sect, 4.3.

Utilizing these formulas and the fuel element descriptions, the capital cost estimates for each case in the study were calculated. These are given in Table B-1.*

\subsubsection{Operating costs}

As with the metal-clad fuels estimates, two operating cost increment categories were defined. One is called operating costs, which include labor, supervision, overhead, general and administrative, utilities, and miscellaneous supplies. The second category, materials costs, is predominately materials included in the finished assemblies (hardware costs), but also includes expendable materials such as those used in the process, chemicals for scrap and waste treatment, containers, etc.

The operating costs for the reference plants were derived by analysis of an organization chart, similar to the example given in Fig. 15 for the metal-clad fuels plant, to define the manpower requirements. This was supplemented with estimates of the utility and miscellaneous materials costs. Derivation of operating costs for the alternative fuels was made by scaling. Here we used the equipment capacity ratios and a scaling factor of 0.8 to determine operating costs for an alternative plant. The details of the operating costs are given in Table B-2.

The materials costs were derived from current cost experience, with rational modifications to increased production demands. These costs are directly proportional to the number of fuel elements produced for a given case. Details are presented in Table B-3.

As with the metal-clad fuels, the plant operational mode was assumed to be that of the toll processor. Thus, there are no costs included for the fissile uranium and plutonium or the fertile thorium materials. In Table B-3, for example, the $\mathrm{ThO}_{2}$ fertile particles are considered a hardware item, but only the costs of processing and quality assurance are included. The "uranium penalty" in the fertile particles for the $\mathrm{MEU} / \mathrm{Th}$ case is included to account for the added processing controls, materials accountability, and scrap and waste treatment required for this material.

\subsection{Scaling Factors for Fabrication and Refabrication Plants}

As stated earlier in this report, the unit costs of fuel fabrication and refabrication are derived from these cost estimates, and the unit costs are submitted to the NASAP and INFCE programs. These programs require unit costs for plants of different sizes. Since a standard plant size (2 MT HM/d) was used in this work, it was necessary to develop scaling factors to permit the determination of unit costs for plants differing only in size.

A standard equation for estimating costs as a function of capacity is

$$
C_{u}=C_{0}\left(X_{u} / X_{0}\right)^{Y},
$$

\footnotetext{
*Tables B-1 to B-3 are presented in Appendix B.
} 
where

$C_{u}=$ cost of a plant of any size in a given cost category,

$C_{0}=$ cost of the reference plant in a given cost category,

$X_{u}=$ capacity of any plant,

$X_{0}=$ capacity of the reference plant,

$Y=$ scaling factor exponent for the given cost category.

The cost estimates presented here were divided into four cost categories - capital cost of facility, capital cost of equipment, annual operating costs, and annual material costs. Each of these cost categories was examined to determine the appropriate value of the exponent $Y$. The values of $Y$ that were determined to be appropriate were:

\section{Cost category}

Capital cost of facility

Capital cost of equipment

Material cost

Operating cost
$\mathbf{Y}$

0.6 (contact plants)

0.8 (remote plants)

0.7

1.0

0.8

Contact fabrication facilities are fairly similar to standard processing facilities with respect to added space requirements to allow increased production. Thus the standard "six-tenths factor" 13 was considered appropriate for this category. For remote fabrication facilities, we assumed a capacity limit of $1 \mathrm{MT} / \mathrm{d}$ for each process line due to space and shielding requirements. The result of this consideration was that in order to double production, the number of process lines had to be doubled. Space savings were realized in boundary areas and in some auxiliary areas, and the resulting area increase amounted to about $75 \%$ for a plant of two times the reference plant capacity. This $75 \%$ area increase amounts to an exponent $Y$ value of 0.8 . Our assumption was that unit building material costs were constant and that the exponent 0.8 is appropriate for facility capital cost as well as area.

Variations in equipment requirements with plant capacity are virtually independent of the mode of operation (contact or remote). Thus the same capacity scaling factor exponent (0.7) was used for both contact and remote-operation plants. Typical exponents for equipment cost as a function of capacity were obtained from the Chemical Engineers' Handbook. ${ }^{14}$ These exponents were used for guidance in establishing the value of our exponent. As evidenced from the information contained in the handbook, exponents vary considerably with type of equipment, but by selecting exponents for equipment of reasonable similarity to that in the fabrication and refabrication plants, and by weighting individual exponents, we obtained a value of about 0.7 for the exponent applicable to our total equipment.

Material (direct materials, supplies, and hardware) requirements are directly proportional to the number of fuel assemblies fabricated. Since the fabrication plants considered in ORNL/TM-6522 ${ }^{4}$ were of sufficient size that cost savings due to quantity buying were not realized, an exponent of 1.0 was considered appropriate for the material cost category. We do recognize that indirect materials and supplies requirements such as those related to number of employees are not directly proportional to plant capacity. However, these indirect materials and supplies represent a very small fraction of total materials requirements and do not have an appreciable impact on the exponent value. 
Operating cost variations are principally influenced by personnel costs. Savings in personnel costs with increased capacity are realized by a reduction in the percentage of personnel devoted to overhead duties. Our analysis of PWR fuel fabrication plants suggests that a doubling of the capacity of a plant would result in an increase of about $70 \%$ in personnel costs. When personnel cost increases were combined with utility and overhead (other than personnel) cost increases, total operating costs increased by about $75 \%$ with a doubling of capacity. An exponent of 0.8 provides this rate of increase.

\section{SUMMARY AND CONCLUSIONS}

In the preceding sections we have described in some detail the methodology used in estimating basic fuel fabrication cost increments. In essence the methodology required the use of a well-defined reference plant cost estimate as the basis. The alternative fuel cases are derived by a systematic function-by-function review with assignment of appropriate incremental multipliers to each function. The incremental multipliers are based on changes in fuel element design, process complexity, working environment requirements, material characteristics, and functional capacity requirements.

Capital (facility and equipment), operating, and material costs for all fuels considered in this study are presented in Table 10. These are the basic costs used as input for the economic analyses to determine prices for each of the fuels as presented in ORNL/TM-6522. ${ }^{4}$ The unit price analysis formula used is given in Table 11. The basic cost estimates were used in this formula to provide values of $C_{D}$ (capital expenditures for facility and equipment), $O$ (annual operation cost), and $M$ (annual material cost). In the formulation, $O$ includes interest on working capital, where working capital requirements are equal to 90 days of receivables on all operating and materials costs. The working capital charges are not included in any of the estimates presented in this report.

The objectives of this study were to provide a consistent set of cost estimates for fabrication of reactor fuels for a large number of possible alternatives and to provide reasonably accurate price estimates (costs to the reactor), for each of the fuel cycles addressed, for use in a broader economic analysis of alternative reactor fuel cycles.

The methodology discussed in this report is an extension of that used in an earlier cost estimation study, which was reviewed by several industrial and government organizations. As a result of that review, the basic methodology was retained, but the level of detail was increased. This was done to increase both the consistency and the accuracy of the estimates. In terms of consistency, the results presented in ORNL/TM- 6522 have been extensively reviewed by the similar groups, and general concurrence on the cost estimates and the cost differentials has been obtained. Throughout the study, emphasis was placed on identifying and quantifying cost differences; as a result, the relative costs (or cost differences) are considered to be significantly more valid than the individual cost estimates.

In terms of the accuracy of the costs, it must be recognized that, at best, they were based on concepts for the different fuels; consequently, a high contingency of 30 to $35 \%$ was included in all of the capital-cost estimates. More precise cost estimates can only be obtained with additional detailed design work on each process. However, where it was possible, the estimates and resulting prices were compared with existing plants or estimates made by others. These comparisons substantiate the estimates and provide reasonable assurance that the unit cost estimates are accurate to within $\pm 25 \%$. Thus they do provide a reasonable input to broad fuel-cycle economic analyses.

The methodology provides a means of producing consistent and reasonably accurate basic cost estimates for a wide range of fuel fabrication processes. When these estimated costs are subjected to uniform economic analyses, the resulting fuel fabrication prices are also consistent and reasonably accurate. 
Table 10. Summary of estımated costs for fabrication and refabrication of LWR, SSCR, HWR, LMFBR, and HTGR fuels

\begin{tabular}{|c|c|c|c|c|}
\hline \multirow[b]{2}{*}{ I uel crcle ${ }^{a}$} & \multicolumn{4}{|c|}{ Lstimated costs $\left(\$ 10^{6}\right)$} \\
\hline & I dclity & Fquipment & $\begin{array}{l}\text { Annudl hardware } \\
\text { and material }\end{array}$ & $\begin{array}{c}\text { Annual } \\
\text { operatıng } b\end{array}$ \\
\hline
\end{tabular}

\begin{tabular}{|c|c|c|c|c|}
\hline \multicolumn{5}{|l|}{ LWR/SSCR } \\
\hline$\left({ }^{235} \mathrm{U}, \mathrm{U}\right) \mathrm{O}_{2}$ & 320 & 342 & 230 & 134 \\
\hline$\left({ }^{235} \mathrm{U} T h\right) O$ & 348 & 465 & 245 & 139 \\
\hline$\left({ }^{2}{ }^{3}{ }^{3} \mathrm{U}, \mathrm{U}\right) \mathrm{O}_{2}$ & 4705 & 2492 & 272 & 244 \\
\hline$\left({ }^{2}{ }^{3}{ }^{3} \mathrm{U}, \mathrm{Th}\right) \mathrm{O}_{2}$ & 5098 & 2657 & 274 & 249 \\
\hline$(\mathrm{Pu}, \mathrm{U}) \mathrm{O}_{2}$ & 2084 & 2085 & 276 & 240 \\
\hline$(\mathrm{Pu}, \mathrm{U}) \mathrm{O}_{2} *$ & 5127 & 2677 & 278 & 249 \\
\hline$(\mathrm{Pu}, \mathrm{Th}) \mathrm{O}_{2}$ & 2248 & 2113 & 282 & 241 \\
\hline$(\mathrm{Pu} \mathrm{Th}) \mathrm{O}_{2}{ }^{*}$ & 5194 & 2657 & 286 & 249 \\
\hline \multicolumn{5}{|l|}{ HWR } \\
\hline $\mathrm{UO}_{2}-$ ndturd & 179 & 274 & 108 & 95 \\
\hline$\left({ }^{2}{ }^{5} \mathrm{U}, \mathrm{U}\right) \mathrm{O}_{2}$ & 213 & 332 & 112 & 110 \\
\hline$\left({ }^{2}{ }^{35} \mathrm{U}, \mathrm{Th}\right) \mathrm{O}_{2}$ & 226 & 442 & 125 & 114 \\
\hline$\left({ }^{2}{ }^{3}{ }^{3} \mathrm{U}, \mathrm{U}\right) \mathrm{O}_{2}$ & 4145 & 2270 & 163 & 177 \\
\hline$\left({ }^{2}{ }^{3}{ }^{3} \mathrm{U}, \mathrm{Th}\right) \mathrm{O}_{2}$ & 4530 & 2473 & 177 & 178 \\
\hline$(\mathrm{Pu}, \mathrm{U}) \mathrm{O}_{2}$ & 1945 & 1953 & 167 & 174 \\
\hline$(\mathrm{Pu}, \mathrm{U}) \mathrm{O}_{2} *$ & 4541 & 2463 & 168 & 178 \\
\hline$(\mathrm{Pu}, \mathrm{Th}) \mathrm{O}$ & 2070 & 1963 & 181 & 174 \\
\hline$(\mathrm{Pu}, \mathrm{Th}) \mathrm{O}_{2}{ }^{*}$ & 4635 & 2463 & 185 & 178 \\
\hline \multicolumn{5}{|l|}{ LMI BR - oxides } \\
\hline$\left({ }^{235} \mathrm{U}, \mathrm{Th}\right) \mathrm{O}_{2} / \mathrm{ThO}_{2}$ & 503 & 815 & 818 & 157 \\
\hline$\left({ }^{233} \mathrm{U}, \mathrm{Th}\right) \mathrm{O}_{2} / \mathrm{ThO}_{2}$ & 10008 & 2915 & 827 & 264 \\
\hline$(\mathrm{Pu}, \mathrm{U}) \mathrm{O}_{2} / \mathrm{UO}_{2}$ & 3575 & 2319 & 768 & 251 \\
\hline$(\mathrm{Pu}, \mathrm{U}) \mathrm{O}_{2} / \mathrm{UO}_{2}$ & 9383 & 2744 & 768 & 266 \\
\hline$(\mathrm{Pu}, \mathrm{Th}) \mathrm{O}_{2} / \mathrm{ThO}_{2}$ & 3575 & 2319 & 827 & 257 \\
\hline$(\mathrm{Pu}, \mathrm{Th}) \mathrm{O} / \mathrm{ThO}_{2}{ }^{*}$ & 10195 & 3097 & 827 & 269 \\
\hline $\mathrm{UO}_{2}(\mathrm{RB})^{\mathrm{c}}$ & 243 & 336 & 331 & 134 \\
\hline $\mathrm{ThO}_{2}(\mathrm{RB})$ & 259 & 369 & 363 & 134 \\
\hline $\mathrm{ThO}_{2}(\mathrm{RB})^{*}$ & 4783 & 3338 & 335 & 264 \\
\hline \multicolumn{5}{|l|}{ LMI BR - carbides } \\
\hline$\left({ }^{2}{ }^{3}{ }^{3} \mathrm{U}, \mathrm{Th}\right) \mathrm{C} / \mathrm{ThC}$ & 9487 & 2944 & 704 & 271 \\
\hline$(\mathrm{Pu}, \mathrm{U}) \mathrm{C} / \mathrm{UC}$ & 3616 & 2452 & 632 & 255 \\
\hline$(\mathrm{Pu}, \mathrm{U}) \mathrm{C} / \mathrm{UC}^{*}$ & 9155 & 2902 & 632 & 268 \\
\hline$(\mathrm{Pu}, \mathrm{Th}) \mathrm{C} / \mathrm{ThC}$ & 3684 & 2489 & 704 & 258 \\
\hline$(\mathrm{Pu}, \mathrm{Th}) \mathrm{C} / \mathrm{ThC}$ & 9487 & 2949 & 704 & 271 \\
\hline $\mathrm{UC}(\mathrm{RB})$ & 353 & 565 & 306 & 134 \\
\hline ThC (RB) & 365 & 611 & 380 & 134 \\
\hline ThC $(\mathrm{RB})^{*}$ & 7830 & 2517 & 351 & 271 \\
\hline \multicolumn{5}{|l|}{ LMI BR metals } \\
\hline${ }^{2}{ }^{3} \mathrm{U}, \mathrm{Th} / \mathrm{Th}$ & 9345 & 2597 & 711 & 288 \\
\hline $\mathrm{Pu}, \mathrm{U}, \mathrm{Zr} / \mathrm{U}$ & 3396 & 2028 & 713 & 270 \\
\hline $\mathrm{Pu}, \mathrm{U}, \mathrm{Zr} / \mathrm{U}^{*}$ & 8415 & 2357 & 713 & 284 \\
\hline $\mathrm{Pu}, \mathrm{Th} / \mathrm{Th}$ & 3792 & 2196 & 711 & 277 \\
\hline $\mathrm{Pu}, \mathrm{Th} / \mathrm{Th} \mathrm{h}^{*}$ & 9345 & 2597 & 711 & 288 \\
\hline $\mathrm{U}(\mathrm{RB})$ & 339 & 317 & 282 & 134 \\
\hline Th (RB) & 382 & 378 & 381 & 134 \\
\hline Th $(\mathrm{RB})^{*}$ & 7633 & 2127 & 352 & 288 \\
\hline
\end{tabular}


Table 10 (continued)

\begin{tabular}{|c|c|c|c|c|}
\hline \multirow[b]{2}{*}{ I uel cycle $a$} & \multirow{2}{*}{ l acility } & \multicolumn{2}{|c|}{ L.st Imated costs $\left(\$ 10^{6}\right)$} & \multirow[b]{2}{*}{$\underset{\text { operdtıng }}{\text { Annual }}$} \\
\hline & & 1 quipment & $\begin{array}{l}\text { Annudl hardware } \\
\text { and material }\end{array}$ & \\
\hline \multicolumn{5}{|l|}{ HTGR } \\
\hline OT-1 (LI U-stowdwdy) & 870 & 266.0 & 184.0 & 22.5 \\
\hline OT-2 (MI U-stowawdy) & 81.0 & 260.0 & 168.0 & 20.2 \\
\hline OT-3 (MEU-stowdwdy) & 76.0 & 2440 & 157.0 & 18.9 \\
\hline $\mathrm{R}-1\left({ }^{235} \mathrm{M} F \mathrm{U} / \mathrm{Th}\right)$ & 710 & 2270 & 146.0 & 18.9 \\
\hline R-1 (MEU/Th)* & 3950 & 8090 & 1130 & 39.7 \\
\hline $\mathrm{R}-2\left({ }^{233} \mathrm{MLU} / \mathrm{Th}\right) *$ & 3200 & 807.0 & 880 & 39.7 \\
\hline $\mathrm{R}-3(\mathrm{Pu} / \mathrm{Th}) *$ & 5690 & 8070 & 172.0 & 35.7 \\
\hline R-4 (HГ U/Th) & 510 & 1660 & 940 & 13.4 \\
\hline R-4 (HI.U/Th)* & 3040 & 4980 & 890 & 236 \\
\hline $\mathrm{R}-5\left({ }^{23}{ }^{3} \mathrm{HI} \mathrm{U} / \mathrm{Th}\right) *$ & 2650 & 4500 & 784 & 23.0 \\
\hline
\end{tabular}

$a_{1}$ uel descriptions indicate tissile indterial, tertile material, and dxidl blanket (if applicable) material All ${ }^{23}$ ' $U$ tuels are tabricated in contact-operated and -maintaned tacities, ${ }^{23} U$ tuels are tabricated in remotely operated and maintaned facilities, and Pu fuels are fabricated in remotely operated and either contact or remotely mantaned taclities Recycled Th is fabricated in remotely operated and mantained tacilities The asterısks indicate the remotely operated and mantained Pu or Th tacilities.

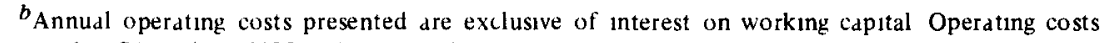
presented in ORNL/TM-6522 include this charge

' $R B$ refers to radial blanket material

Table 11. Unit price analysis formula

\begin{tabular}{l} 
$\$ / \mathrm{kg}=\left[\left(C_{D}+C_{O}+C_{C}\right) R+O+M+E_{R}+D\right] / T$ \\
where $^{a}$ \\
$C_{D}=$ facility plus equipment costs, $C_{F}+C_{E}$ \\
$C_{F}=$ facility cost (excluding process equipment) \\
$C_{E}=$ equipment cost \\
$C_{O}=$ owner's cost durıng construction \\
$C_{C}=$ charge on direct capital during construction, $I_{O} C_{O}+I_{D} C_{D}$ \\
$I_{D}=$ fractional charge on design and construction cost during construction \\
$I_{O}=$ fractional charge on owner's cost during construction \\
$R=$ annual fixed charge rate on capital, fraction per year \\
$O=$ annual operating cost \\
$M=$ annual hardware and expendable material cost \\
$A_{R}=$ annual maintenance and replacement rate on equipment, fraction per year \\
$E_{R}=$ annual maintenance and replacement cost, $A_{R} C_{E}$ \\
$D=$ annual payment to establish fund for decommissioning \\
$T=$ annual throughput achieved, Gg/year, $X F$ \\
$X=$ design capacity of plant, Gg/year \\
$F=$ average fraction of design capacity achieved \\
\hline
\end{tabular}

${ }^{a}$ All costs in millions of dollars. 


\section{REFERENCES}

1. R. R. Judkins and A. R. Olsen, Estimation of Costs for Fabrication of Pressurized-Water Reactor Fuel, ORNL/TM-6501 (January 1979).

2. Conceptual Design Summary and Design Qualifications for HTGR Target Recycle Plant, General Atomic Company, GA-A13365 (Apr. 30, 1975).

3. A. R. Olsen, Thorium Fuel Cycle Studies - Fuel Fabrication Process and Cost Estimation, ORNL/TM.5961 (in press).

4. A. R. Olsen, R. R. Judkins, W. L. Carter, and J. G. Delene, Fuel Cycle Cost Studies - Fabrication, Reprocessing, and Refabrication of LWR, SSCR, HWR, LMFBR, and HTGR Fuels, ORNL/TM-6522 (March 1979).

5. RESAR-3S. Reference Safety Analysis Report, Volume 2, Docket STN 50545-2, Westinghouse Electric Corporation, Pittsburgh (July 1975).

6. System 80 - Preliminary Safety Analysis Report - Combustion Engineering Standard Safety Analysis Report, Volume 4, Amendment 3, Docket STN 50470, Combustion Engineering, Inc., Windsor, Connecticut (June 3, 1974).

7. Data Base for a CANDU-PHWR Operating on a Once-Through Natural Uranium Cycle, INFCE/WG.8/CAN/DOC, draft submission to INFCE working group 8: Advanced Fuel Cycle and Reactor Concepts (October 1978).

8. Y. A. Chang, Argonne National Laboratory, personal communication to J. M. Cleveland, Oak Ridge National Laboratory (April-May 1978).

9. A. J. Neylan, General Atomic Company, personal communication to K. O. Laughon, Department of Energy (Mar. 3, 1978); R. K. Lane, General Atomic Company, personal communication to A. R. Olsen, Oak Ridge National Laboratory (July 17, 1978).

10. High-Temperature Gas-Cooled Reactors - Once-Through Cycles, INFCE working group 8: Advanced Fuel Cycle and Reactor Concepts; subgroup A: Once-Through Cycles, draft report (July 1978).

11. High-Temperature Gas-Cooled Reactors - Operating on Fuel Recycle, INFCE working group 8: Advanced Fuel Cycle and Reactor Concepts: subgroup B: Alternate Recycle Cases, draft report (July 1978).

12. Gas-Cooled Reactor Commercialization Study - Interim Report, R. A. McCormick Company, prepared for Department of Energy (Oct. 31, 1977).

13. R. Williams, Chem. Eng. S4(12), 124 (1947).

14. R. H. Perry, C. H. Chilton, and S. D. Kirkpatrick (eds.), Chemical Engineers' Handbook, 4th ed., McGraw-Hill, New York, 1963. 
Appendix A

SUMMARY OF CAPITAL, OPERATING, AND

MATERIALS COSTS ESTIMATES FOR METAL-CLAD FUELS

Note:

In the following tables these footnotes apply:

${ }^{a}$ Remote operation and contact maintenance.

$b_{\text {Remote operation and remote maintenance. }}$

${ }^{c} \mathrm{RB}$ - radial blanket. 
Table A-1. Space Requirements for Process Functions in PWR Fuel Fabrication and Refabrication Plants

\begin{tabular}{|c|c|c|c|c|c|c|c|c|}
\hline \multirow{2}{*}{ Functional Area } & \multicolumn{8}{|c|}{ Space Requirements for Fuel Type, $\mathrm{m}^{2}\left(\mathrm{ft}^{2}\right)$} \\
\hline & $\left({ }^{235} \mathrm{U}, \mathrm{U}\right) \mathrm{O}_{2}$ & $(235 \mathrm{U}, \mathrm{Th}) \mathrm{O}_{2}$ & $\left({ }^{233} \mathrm{U}, \mathrm{U}\right) \mathrm{O}_{2}$ & $\left({ }^{233} \mathrm{U}, \mathrm{Th}\right) \mathrm{O}_{2}$ & $(\mathrm{Pu}, \mathrm{U}) \mathrm{O}_{2}^{a}$ & $(\mathrm{Pu}, \mathrm{U}) \mathrm{O}_{2}^{b}$ & $(\mathrm{Pu}, \mathrm{Th}) \mathrm{O}_{2}{ }^{a}$ & $(\mathrm{Pu}, \mathrm{Th}) \mathrm{O}_{2}^{b}$ \\
\hline $\mathrm{UF}_{6}$ Receipt and Conversion & $\begin{array}{c}511 \\
(5,500)\end{array}$ & $\begin{array}{c}93 \\
(1,000)\end{array}$ & & & & & & \\
\hline Powder Receipt and Storage & & $\begin{array}{c}158 \\
(1,700)\end{array}$ & $\begin{array}{c}411 \\
(4,420)\end{array}$ & $\begin{array}{c}411 \\
(4,420)\end{array}$ & $\begin{array}{c}411 \\
(4,420)\end{array}$ & $\begin{array}{c}411 \\
(4,420)\end{array}$ & $\begin{array}{c}411 \\
(4,420)\end{array}$ & $\begin{array}{c}411 \\
(4,420)\end{array}$ \\
\hline Powder Preparation & $\begin{array}{c}437 \\
(4,700)\end{array}$ & $\begin{array}{c}497 \\
(5,350)\end{array}$ & $\begin{array}{c}628 \\
(6,760)\end{array}$ & $\begin{array}{c}628 \\
(6,760)\end{array}$ & $\begin{array}{c}628 \\
(6,760)\end{array}$ & $\begin{array}{c}628 \\
(6,760)\end{array}$ & $\begin{array}{c}628 \\
(6,760)\end{array}$ & $\begin{array}{c}628 \\
(6,760)\end{array}$ \\
\hline Pelletization & $\begin{array}{c}177 \\
(1,900)\end{array}$ & $\begin{array}{c}232 \\
(2,500)\end{array}$ & $\begin{array}{c}302 \\
(3,250)\end{array}$ & $\begin{array}{c}302 \\
(3,250)\end{array}$ & $\begin{array}{c}302 \\
(3,250)\end{array}$ & $\begin{array}{c}302 \\
(3,250)\end{array}$ & $\begin{array}{c}302 \\
(3,250)\end{array}$ & $\begin{array}{c}302 \\
(3,250)\end{array}$ \\
\hline $\begin{array}{l}\text { Pellet Sintering, Grinding, } \\
\text { and Inspection }\end{array}$ & $\begin{array}{c}543 \\
(5,850)\end{array}$ & $\begin{array}{c}776 \\
(8,350)\end{array}$ & $\begin{array}{c}1,479 \\
(15,925)\end{array}$ & $\begin{array}{c}1,649 \\
(17,745)\end{array}$ & $\begin{array}{c}1,714 \\
(18,445)\end{array}$ & $\begin{array}{c}1,750 \\
(18,835)\end{array}$ & $\begin{array}{c}1,950 \\
(20,995)\end{array}$ & $\begin{array}{c}1,987 \\
(21,385)\end{array}$ \\
\hline $\begin{array}{l}\text { Fuel Rod Loading and } \\
\text { Welding }\end{array}$ & $\begin{array}{c}258 \\
(2,780)\end{array}$ & $\begin{array}{c}322 \\
(3,470)\end{array}$ & $\begin{array}{c}566 \\
(6,095)\end{array}$ & $\begin{array}{c}566 \\
(6,095)\end{array}$ & $\begin{array}{c}524 \\
(5,645)\end{array}$ & $\begin{array}{c}566 \\
(6,095)\end{array}$ & $\begin{array}{c}524 \\
(5,645)\end{array}$ & $\begin{array}{c}566 \\
(6,095)\end{array}$ \\
\hline $\begin{array}{l}\text { Fuel Rod Inspection and } \\
\text { Storage }\end{array}$ & $\begin{array}{c}650 \\
(7,000)\end{array}$ & $\begin{array}{c}697 \\
(7,500)\end{array}$ & $\begin{array}{c}2,899 \\
(31,200)\end{array}$ & $\begin{array}{c}2,899 \\
(31,200)\end{array}$ & $\begin{array}{c}1,570 \\
(16,900)\end{array}$ & $\begin{array}{c}2,899 \\
(31,200)\end{array}$ & $\begin{array}{c}1,751 \\
(18,850)\end{array}$ & $\begin{array}{c}2,899 \\
(31,200)\end{array}$ \\
\hline Fuel Assembly Fabrication & $\begin{array}{c}279 \\
(3,000)\end{array}$ & $\begin{array}{c}348 \\
(3,750)\end{array}$ & $\begin{array}{c}1,691 \\
(18,200)\end{array}$ & $\begin{array}{c}1,691 \\
(18,200)\end{array}$ & $\begin{array}{c}1,208 \\
(13,000)\end{array}$ & $\begin{array}{c}1,691 \\
(18,200)\end{array}$ & $\begin{array}{c}1,208 \\
(13,000)\end{array}$ & $\begin{array}{c}1,691 \\
(18,200)\end{array}$ \\
\hline Fuel Assembly Inspection & $\begin{array}{c}316 \\
(3,400)\end{array}$ & $\begin{array}{c}347 \\
(3,740)\end{array}$ & $\begin{array}{c}1,232 \\
(13,265)\end{array}$ & $\begin{array}{c}1,232 \\
(13,265)\end{array}$ & $\begin{array}{c}862 \\
(9,280)\end{array}$ & $\begin{array}{c}1,232 \\
(13,265)\end{array}$ & $\begin{array}{c}945 \\
(10,170)\end{array}$ & $\begin{array}{c}1,232 \\
(13,265)\end{array}$ \\
\hline $\begin{array}{l}\text { Fuel Assembly Packaging, } \\
\text { Storage, and Shipping }\end{array}$ & $\begin{array}{c}372 \\
(4,000)\end{array}$ & $\begin{array}{c}557 \\
(6,000)\end{array}$ & $\begin{array}{c}4,831 \\
(52,000)\end{array}$ & $\begin{array}{c}4,831 \\
(52,000)\end{array}$ & $\begin{array}{c}2,899 \\
(31,200)\end{array}$ & $\begin{array}{c}4,831 \\
(52,000)\end{array}$ & $\begin{array}{c}2,899 \\
(31,200)\end{array}$ & $\begin{array}{c}4,831 \\
(52,000)\end{array}$ \\
\hline $\begin{array}{l}\text { Scrap Recovery and Waste } \\
\text { Processing }\end{array}$ & $\begin{array}{c}186 \\
(2,000)\end{array}$ & $\begin{array}{c}279 \\
(3,000)\end{array}$ & $\begin{array}{c}1,208 \\
(13,000)\end{array}$ & $\begin{array}{c}1,812 \\
(19,500)\end{array}$ & $\begin{array}{c}1,208 \\
(13,000)\end{array}$ & $\begin{array}{c}1,812 \\
(19,500)\end{array}$ & $\begin{array}{c}1,812 \\
(19,500)\end{array}$ & $\begin{array}{c}1,812 \\
(19,500)\end{array}$ \\
\hline TOTALS & $\begin{array}{c}3,728 \\
(40,130)\end{array}$ & $\begin{array}{c}4,307 \\
(46,360)\end{array}$ & $\begin{array}{c}15,247 \\
(164,115)\end{array}$ & $\begin{array}{c}16,020 \\
(172,435)\end{array}$ & $\begin{array}{c}11,325 \\
(121,900)\end{array}$ & $\begin{array}{c}16,121 \\
(173,525)\end{array}$ & $\begin{array}{c}12,429 \\
(133,790)\end{array}$ & $\begin{array}{c}15,358 \\
(176,075)\end{array}$ \\
\hline
\end{tabular}


Table A-2. Facility Capital Costs for PWR Fuel Fabrication and Refabrication Plants

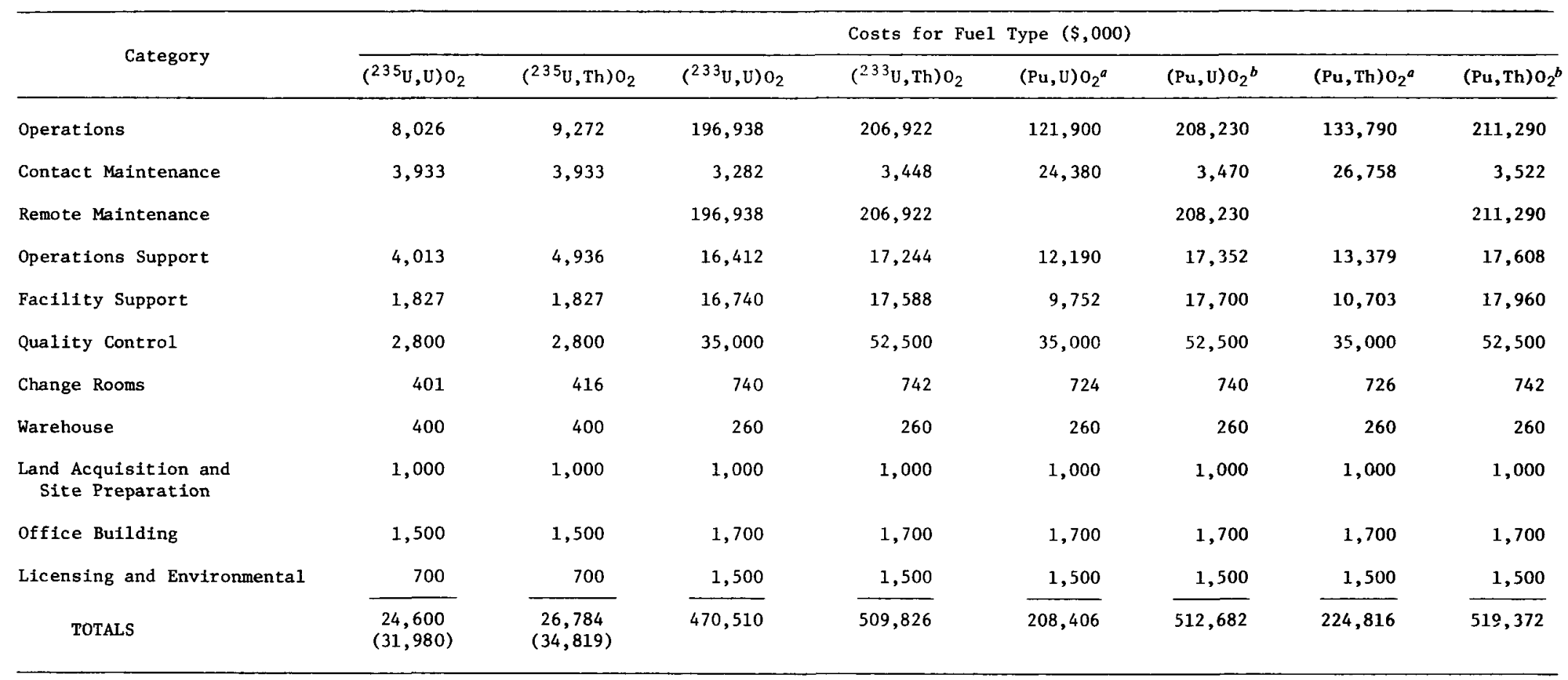


Table A-3. Equipment Capita1 Costs for PWR Fuel Fabrication and Refabrication Plants

\begin{tabular}{|c|c|c|c|c|c|c|c|c|}
\hline \multirow{2}{*}{ Category } & \multicolumn{8}{|c|}{ Costs for Fuel Type $(\$, 000)$} \\
\hline & $\left({ }^{235} \mathrm{U}, \mathrm{U}\right) \mathrm{O}_{2}$ & $\left({ }^{235} \mathrm{U}, \mathrm{Th}\right) \mathrm{O}_{2}$ & $\left({ }^{23}{ }^{3} \mathrm{U}, \mathrm{U}\right) \mathrm{O}_{2}$ & $\left({ }^{23}{ }^{3} \mathrm{U}, \mathrm{Th}\right) \mathrm{O}_{2}$ & $(\mathrm{Pu}, \mathrm{U}) \mathrm{O}_{2}{ }^{a}$ & $(\mathrm{Pu}, \mathrm{U}) \mathrm{O}_{2} \mathrm{~b}$ & $(\mathrm{Pu}, \mathrm{Th}) \mathrm{O}_{2}^{a}$ & $(\mathrm{Pu}, \mathrm{Th}) \mathrm{O}_{2} b$ \\
\hline Operations & 11,380 & 15,496 & 105,604 & 112,536 & 94,924 & 112,136 & 96,074 & 112,536 \\
\hline Contact Maintenance & 11,380 & 15,496 & & & 74,924 & & 76,074 & \\
\hline Remote Maintenance & & & 95,604 & 102,536 & & 102,136 & & 102,536 \\
\hline Operations Support & 4,268 & 5,811 & 5,811 & 5,811 & 5,811 & 5,811 & 5,811 & 5,811 \\
\hline Facility Support & 5,690 & 7,748 & 35,852 & 38,451 & 28,097 & 38,301 & 28,528 & 38,451 \\
\hline Quality Control & 1,423 & 1,937 & 6,272 & 6,272 & 4,704 & 6,272 & 4,704 & 6,272 \\
\hline Warehouse & 60 & 60 & 78 & 78 & 78 & 78 & 78 & 78 \\
\hline TOTALS & 34,201 & 46,548 & 249,221 & 265,684 & 208,538 & 264,734 & 211,269 & 265,684 \\
\hline
\end{tabular}

Table A-4. Annual Operating Costs for PWR Fuel Fabrication and Refabrication Plants

\begin{tabular}{|c|c|c|c|c|c|c|c|c|}
\hline \multirow{2}{*}{ Cost Category } & \multicolumn{8}{|c|}{ Costs for Fuel Type $(\$, 000)$} \\
\hline & $(235 \mathrm{U}, \mathrm{U}) \mathrm{O}_{2}$ & $\left({ }^{235} \mathrm{U}, \mathrm{Th}\right) \mathrm{O}_{2}$ & $\left({ }^{233} \mathrm{U}, \mathrm{U}\right) \mathrm{O}_{2}$ & $\left({ }^{23}{ }^{3} \mathrm{U}, \mathrm{Th}\right) \mathrm{O}_{2}$ & $(\mathrm{Pu}, \mathrm{U}) \mathrm{O}_{2}{ }^{a}$ & $(\mathrm{Pu}, \mathrm{U}) \mathrm{O}_{2}^{b}$ & $(\mathrm{Pu}, \mathrm{Th}) \mathrm{O}_{2}{ }^{a}$ & $(\mathrm{Pu}, \mathrm{Th}) \mathrm{O}_{2} b$ \\
\hline Personnel (Variable) & 10,164 & 10,499 & 18,223 & 18,488 & 18,490 & 18,489 & 18,117 & 18,488 \\
\hline Personnel (Fixed) & 2,803 & 2,928 & 4,428 & 4,523 & 3,936 & 4,428 & 4,405 & 4,523 \\
\hline Overhead & 177 & 177 & 177 & 177 & 177 & 177 & 177 & 177 \\
\hline Utilities & 239 & 249 & 1,614 & 1,738 & 1,363 & 1,732 & 1,383 & 1,738 \\
\hline TOTALS & $\overline{13,383}$ & $\overline{13,853}$ & $\overline{24,442}$ & $\overline{24,926}$ & $\overline{23,966}$ & $\overline{24,826}$ & $\overline{24,082}$ & $\overline{24,926}$ \\
\hline
\end{tabular}


Table A-5. Annual Materials Costs for PWR Fuel Fabrication and Refabrication Plants

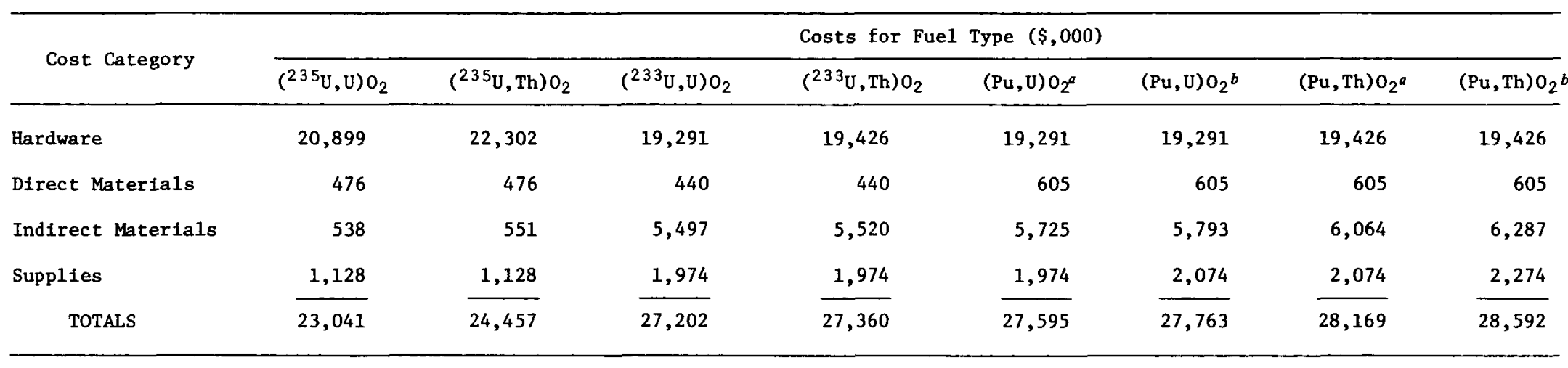


Table A-6. Space Requirements for Process Functions in HWR Fuel Fabrication and Refabrication Plants

\begin{tabular}{|c|c|c|c|c|c|c|c|c|c|}
\hline \multirow{2}{*}{ Functional Area } & \multicolumn{9}{|c|}{ Space Requirements for Fuel Type, $\mathrm{m}^{2}\left(\mathrm{ft}^{2}\right)$} \\
\hline & $\mathrm{UO}_{2}$ (Natura1) & $\left({ }^{235} \mathrm{U}, \mathrm{U}\right) \mathrm{O}_{2}$ & $\left(235_{U}, \mathrm{Th}\right) \mathrm{o}_{2}$ & $\left({ }^{233} \mathrm{U}, \mathrm{U}\right) \mathrm{O}_{2}$ & $\left({ }^{23}{ }^{3} \mathrm{U}, \mathrm{Th}\right) \mathrm{O}_{2}$ & $(\mathrm{Pu}, \mathrm{U}) \mathrm{O}_{2}^{a}$ & $(\mathrm{Pu}, \mathrm{U}) \mathrm{O}_{2}^{b}$ & $(\mathrm{Pu}, \mathrm{Th}) \mathrm{O}_{2}{ }^{a}$ & $(\mathrm{Pu}, \mathrm{Th}) \mathrm{O}_{2}{ }^{b}$ \\
\hline $\mathrm{UF}_{6}$ Receipt and Conversion & $\begin{array}{c}218 \\
(2,350)\end{array}$ & $\begin{array}{c}511 \\
(5,500)\end{array}$ & $\begin{array}{c}255 \\
(2,750)\end{array}$ & & & & & & \\
\hline Powder Receipt and Storage & & & $\begin{array}{c}158 \\
(1,700)\end{array}$ & $\begin{array}{c}411 \\
(4,420)\end{array}$ & $\begin{array}{c}411 \\
(4,420)\end{array}$ & $\begin{array}{c}411 \\
(4,420)\end{array}$ & $\begin{array}{c}411 \\
(4,420)\end{array}$ & $\begin{array}{c}411 \\
(4,420)\end{array}$ & $\begin{array}{c}411 \\
(4,420)\end{array}$ \\
\hline Powder Preparation & $\begin{array}{c}218 \\
(2,350)\end{array}$ & $\begin{array}{c}437 \\
(4,700)\end{array}$ & $\begin{array}{c}497 \\
(5,350)\end{array}$ & $\begin{array}{c}628 \\
(6,760)\end{array}$ & $\begin{array}{c}628 \\
(6,760)\end{array}$ & $\begin{array}{c}628 \\
(6,760)\end{array}$ & $\begin{array}{c}628 \\
(6,760)\end{array}$ & $\begin{array}{c}628 \\
(6,760)\end{array}$ & $\begin{array}{c}628 \\
(6,760)\end{array}$ \\
\hline Pelletization & $\begin{array}{c}177 \\
(1,900)\end{array}$ & $\begin{array}{c}177 \\
(1,900)\end{array}$ & $\begin{array}{c}204 \\
(2,200)\end{array}$ & $\begin{array}{c}266 \\
(2,860)\end{array}$ & $\begin{array}{c}266 \\
(2,860)\end{array}$ & $\begin{array}{c}266 \\
(2,860)\end{array}$ & $\begin{array}{c}266 \\
(2,860)\end{array}$ & $\begin{array}{c}266 \\
(2,860)\end{array}$ & $\begin{array}{c}266 \\
(2,860)\end{array}$ \\
\hline $\begin{array}{l}\text { Pellet Sintering, Grinding, } \\
\text { and Inspection }\end{array}$ & $\begin{array}{c}543 \\
(5,850)\end{array}$ & $\begin{array}{c}543 \\
(5,850)\end{array}$ & $\begin{array}{c}674 \\
(7,250)\end{array}$ & $\begin{array}{c}876 \\
(9,425)\end{array}$ & $\begin{array}{c}1,045 \\
(11,245)\end{array}$ & $\begin{array}{c}1,146 \\
(12,335)\end{array}$ & $\begin{array}{c}1,146 \\
(12,335)\end{array}$ & $\begin{array}{c}1,383 \\
(14,885)\end{array}$ & $\begin{array}{c}1,383 \\
(14,885)\end{array}$ \\
\hline $\begin{array}{l}\text { Fuel Rod Loading and } \\
\text { Welding }\end{array}$ & $\begin{array}{c}234 \\
(2,515)\end{array}$ & $\begin{array}{c}338 \\
(3,640)\end{array}$ & $\begin{array}{c}338 \\
(3,640)\end{array}$ & $\begin{array}{c}1,003 \\
(10,800)\end{array}$ & $\begin{array}{c}1,003 \\
(10,800)\end{array}$ & $\begin{array}{c}837 \\
(9,010)\end{array}$ & $\begin{array}{c}1,003 \\
(10,800)\end{array}$ & $\begin{array}{c}837 \\
(9,010)\end{array}$ & $\begin{array}{c}1,003 \\
(10,800)\end{array}$ \\
\hline $\begin{array}{l}\text { Fuel Rod Inspection and } \\
\text { Storage }\end{array}$ & $\begin{array}{c}719 \\
(7,740)\end{array}$ & $\begin{array}{c}883 \\
(9,500)\end{array}$ & $\begin{array}{c}883 \\
(9,500)\end{array}$ & $\begin{array}{c}1,993 \\
(21,450)\end{array}$ & $\begin{array}{c}1,993 \\
(21,450)\end{array}$ & $\begin{array}{c}1,389 \\
(14,950)\end{array}$ & $\begin{array}{c}1,993 \\
(21,450)\end{array}$ & $\begin{array}{c}1,389 \\
(14,950)\end{array}$ & $\begin{array}{c}1,993 \\
(21,450)\end{array}$ \\
\hline Fuel Assembly Fabrication & $\begin{array}{c}643 \\
(6,925)\end{array}$ & $\begin{array}{c}790 \\
(8,500)\end{array}$ & $\begin{array}{c}790 \\
(8,500)\end{array}$ & $\begin{array}{c}1,389 \\
(14,950)\end{array}$ & $\begin{array}{c}1,389 \\
(14,950)\end{array}$ & $\begin{array}{c}1,027 \\
(11,050)\end{array}$ & $\begin{array}{c}1,389 \\
(14,950)\end{array}$ & $\begin{array}{c}1,027 \\
(11,050)\end{array}$ & $\begin{array}{c}1,389 \\
(14,950)\end{array}$ \\
\hline Fuel Assemb1y Inspection & $\begin{array}{c}190 \\
(2,040)\end{array}$ & $\begin{array}{c}190 \\
(2,040)\end{array}$ & $\begin{array}{c}190 \\
(2,040)\end{array}$ & $\begin{array}{c}657 \\
(7,070)\end{array}$ & $\begin{array}{c}657 \\
(7,070)\end{array}$ & $\begin{array}{c}575 \\
(6,190)\end{array}$ & $\begin{array}{c}657 \\
(7,070)\end{array}$ & $\begin{array}{c}575 \\
(6,190)\end{array}$ & $\begin{array}{c}657 \\
(7,070)\end{array}$ \\
\hline $\begin{array}{l}\text { Fuel Assembly Packaging, } \\
\text { Storage, and Shipping }\end{array}$ & $\begin{array}{c}186 \\
(2,000)\end{array}$ & $\begin{array}{c}186 \\
(2,000)\end{array}$ & $\begin{array}{c}186 \\
(2,000)\end{array}$ & $\begin{array}{c}4,831 \\
(52,000)\end{array}$ & $\begin{array}{c}4,831 \\
(52,000)\end{array}$ & $\begin{array}{c}2,899 \\
(31,200)\end{array}$ & $\begin{array}{c}4,831 \\
(52,000)\end{array}$ & $\begin{array}{c}2,899 \\
(31,200)\end{array}$ & $\begin{array}{c}4,831 \\
(52,000)\end{array}$ \\
\hline $\begin{array}{l}\text { Scrap Recovery and Waste } \\
\text { Processing }\end{array}$ & $\begin{array}{c}139 \\
(1,500)\end{array}$ & $\begin{array}{c}186 \\
(2,000)\end{array}$ & $\begin{array}{c}279 \\
(3,000)\end{array}$ & $\begin{array}{c}1,208 \\
(13,000)\end{array}$ & $\begin{array}{c}1,812 \\
(19,500)\end{array}$ & $\begin{array}{c}1,208 \\
(13,000)\end{array}$ & $\begin{array}{c}1,812 \\
(19,500)\end{array}$ & $\begin{array}{c}1,812 \\
(19,500)\end{array}$ & $\begin{array}{c}1,812 \\
(19,500)\end{array}$ \\
\hline TOTALS & $\begin{array}{c}3,267 \\
(35,170)\end{array}$ & $\begin{array}{c}4,239 \\
(45,630)\end{array}$ & $\begin{array}{c}4,453 \\
(47,930)\end{array}$ & $\begin{array}{c}13,261 \\
(142,735)\end{array}$ & $\begin{array}{c}14,033 \\
(151,055)\end{array}$ & $\begin{array}{c}10,384 \\
(111,775)\end{array}$ & $\begin{array}{c}14,135 \\
(152,145)\end{array}$ & $\begin{array}{c}11,225 \\
(120,825)\end{array}$ & $\begin{array}{c}14,372 \\
(154,695)\end{array}$ \\
\hline
\end{tabular}


Table A-7. Fac1lity Capital Costs for HWR Fuel Fabrication and Refabrication Plants

\begin{tabular}{|c|c|c|c|c|c|c|c|c|c|c|}
\hline \multirow{2}{*}{ Cost Category } & \multicolumn{10}{|c|}{ Costs for Fuel Type $(\$, 000)$} \\
\hline & $\mathrm{UO}_{2}$ & (Natural) & $\left({ }^{235} \mathrm{U}, \mathrm{U}\right) \mathrm{O}_{2}$ & $(235 \mathrm{U}, \mathrm{Th}) \mathrm{O}_{2}$ & $\left({ }^{233} U, U\right) O_{2}$ & $(233 \mathrm{~V}, \mathrm{Th}) \mathrm{O}_{2}$ & $(\mathrm{Pu}, \mathrm{U}) \mathrm{O}_{2}^{a}$ & $(\mathrm{Pu}, \mathrm{U}) \mathrm{O}_{2}^{b}$ & $(\mathrm{Pu}, \mathrm{Th}) \mathrm{O}_{2} \mathrm{a}$ & $(\mathrm{Pu}, \mathrm{Th}) \mathrm{O}_{2}{ }^{b}$ \\
\hline Operations & & 7,034 & 9,126 & 9,586 & 163,408 & 181,404 & 114,288 & 181,503 & 123,519 & 185,820 \\
\hline Contact Maintenance & & 3,204 & 3,933 & 4,778 & 2,723 & 3,023 & 22,858 & 3,025 & 24,704 & 3,097 \\
\hline Remote Maintenance & & & & & 163,408 & 181,404 & & 181,503 & & 185,820 \\
\hline Operations Support & & 1,338 & 1,338 & 1,338 & 13,617 & 15,117 & 11,429 & 15,125 & 12,352 & 15,485 \\
\hline Facility Support & & 1,488 & 1,827 & 1,827 & 13,890 & 15,419 & 5,943 & 15,428 & 6,423 & 15,795 \\
\hline Quality Control & & 1,400 & 1,400 & 1,400 & 52,500 & 52,500 & 35,000 & 52,500 & 35,000 & 52,500 \\
\hline Change Rooms & & 283 & 331 & 340 & 534 & 535 & 524 & 534 & 526 & 535 \\
\hline Warehouse & & 400 & 400 & 400 & 260 & 260 & 260 & 260 & 260 & 260 \\
\hline $\begin{array}{l}\text { Land Acquisition and } \\
\text { Site Preparation }\end{array}$ & & 1,000 & 1,000 & 1,000 & 1,000 & 1,000 & 1,000 & 1,000 & 1,000 & 1,000 \\
\hline Office Building & & 1,057 & 1,237 & 1,227 & 1,700 & 1,700 & 1,700 & 1,700 & 1,700 & 1,700 \\
\hline Licensing and Environmental & & 700 & 700 & 700 & 1,500 & 1,500 & 1,500 & 1,500 & 1,500 & 1,500 \\
\hline TOTALS & & 17,904 & 21,292 & 22,596 & 414,540 & 453,862 & 194,502 & 454,078 & 206,984 & 463,512 \\
\hline
\end{tabular}


Table A-8. Equipment Capital Costs for HWR Fuel Fabrication and Refabrication Plants

\begin{tabular}{|c|c|c|c|c|c|c|c|c|c|c|}
\hline \multirow{2}{*}{ Cost Category } & \multicolumn{10}{|c|}{ Costs for Fuel Type $(\$, 000)$} \\
\hline & $\mathrm{UO}_{2}$ & (Natural) & $(235 \mathrm{U}, \mathrm{U}) \mathrm{O}_{2}$ & $(235 \mathrm{U}, \mathrm{Th}) \mathrm{O}_{2}$ & $\left({ }^{233} \mathrm{U}, \mathrm{U}\right) \mathrm{O}_{2}$ & $\left({ }^{23}{ }^{3} \mathrm{U}, \mathrm{Th}\right) \mathrm{O}_{2}$ & $(\mathrm{Pu}, \mathrm{U}) \mathrm{O}_{2}{ }^{a}$ & $(\mathrm{Pu}, \mathrm{U}) \mathrm{O}_{2}{ }^{b}$ & $(\mathrm{Pu}, \mathrm{Th}) \mathrm{O}_{2^{a}}$ & $(\mathrm{Pu}, \mathrm{Th}) \mathrm{O}_{2}^{b}$ \\
\hline Operations & & 9,093 & 11,012 & 14,678 & 96,495 & 105,040 & 88,955 & 104,640 & 89,355 & 104,640 \\
\hline Contact Maintenance & & 8,983 & 11,012 & 14,678 & & & 68,955 & & 69,355 & \\
\hline Remote Maintenance & & & & & 86,495 & 95,040 & & 94,640 & & 94,640 \\
\hline Operations Support & & 3,372 & 4,130 & 5,504 & 5,504 & 5,504 & 5,504 & 5,504 & 5,504 & 5,504 \\
\hline Facility Support & & 4,497 & 5,506 & 7,339 & 22,436 & 35,640 & 25,858 & 35,490 & 26,008 & 35,490 \\
\hline Quality Control & & 1,497 & 1,497 & 1,974 & 5,988 & 5,988 & 5,988 & 5,988 & 5,988 & 5,988 \\
\hline Warehouse & & 60 & 60 & 60 & 78 & 78 & 78 & 78 & 78 & 78 \\
\hline TOTALS & & 27,412 & 33,217 & 44,233 & 226,996 & 247,290 & 195,338 & 246,340 & 196,288 & 246,340 \\
\hline
\end{tabular}

Table A-9. Annual Operating Costs for HWR Fuel Fabrication and Refabrication Plants

\begin{tabular}{|c|c|c|c|c|c|c|c|c|c|c|}
\hline \multirow{2}{*}{ Cost Category } & \multicolumn{10}{|c|}{ Costs for Fuel Type $(\$, 000)$} \\
\hline & $\mathrm{UO}_{2}$ & (Natural) & $(235 \mathrm{U}, \mathrm{U}) \mathrm{O}_{2}$ & $(235 \mathrm{U}, \mathrm{Th}) \mathrm{O}_{2}$ & $\left({ }^{23}{ }^{3} \mathrm{U}, \mathrm{U}\right) \mathrm{O}_{2}$ & $\left({ }^{233} \mathrm{U}, \mathrm{Th}\right) \mathrm{O}_{2}$ & $(\mathrm{Pu}, \mathrm{U}) \mathrm{O}_{2}{ }^{a}$ & $(\mathrm{Pu}, \mathrm{U}) \mathrm{O}_{2}{ }^{b}$ & $(\mathrm{Pu}, \mathrm{Th}) \mathrm{O}_{2}{ }^{a}$ & $(\mathrm{Pu}, \mathrm{Th}) \mathrm{O}_{2}{ }^{b}$ \\
\hline Personnel (Variable) & & 6,466 & 7,941 & 8,214 & 11,910 & 11,947 & 11,800 & 11,935 & 11,822 & 11,953 \\
\hline Personnel (Fixed) & & 2,642 & 2,642 & 2,760 & 4,174 & 4,200 & 4,111 & 4,174 & 4,130 & 4,200 \\
\hline Overhead & & 177 & 177 & 177 & 177 & 177 & 177 & 177 & 177 & 177 \\
\hline Utilities & & 179 & 217 & 237 & 1,485 & 1,518 & 1,278 & 1,512 & 1,285 & 1,512 \\
\hline TOTALS & & 9,464 & 10,977 & 11,388 & 17,746 & 17,842 & 17,366 & 17,798 & 17,414 & 17,842 \\
\hline
\end{tabular}


Table A-10. Annual Materials Costs for HWR Fuel Fabrication and Refabrication Plants

\begin{tabular}{|c|c|c|c|c|c|c|c|c|c|}
\hline \multirow{2}{*}{ Cost Category } & \multicolumn{9}{|c|}{ Costs for Fuel Type $(\$, 000)$} \\
\hline & $\mathrm{UO}_{2}$ (Natural) & $\left({ }^{235} \mathrm{U}, \mathrm{U}\right) \mathrm{O}_{2}$ & $(235 \mathrm{U}, \mathrm{Th}) \mathrm{O}_{2}$ & $\left({ }^{23}{ }^{3} \mathrm{U}, \mathrm{U}\right) \mathrm{O}_{2}$ & $\left(23{ }^{3} \mathrm{U}, \mathrm{Th}\right) \mathrm{O}_{2}$ & $(\mathrm{Pu}, \mathrm{U}) \mathrm{O}_{2}^{a}$ & $(\mathrm{Pu}, \mathrm{U}) \mathrm{O}_{2}^{b}$ & $(\mathrm{Pu}, \mathrm{Th}) \mathrm{O}_{2}^{a}$ & $(\mathrm{Pu}, \mathrm{Th}) \mathrm{O}_{2}^{b}$ \\
\hline Hardware & 9,064 & 9,064 & 10,398 & 8,366 & 9,598 & 8,366 & 8,366 & 9,598 & 9,598 \\
\hline Direct Materials & 476 & 476 & 476 & 440 & 440 & 605 & 605 & 605 & 605 \\
\hline Indirect Materials & 538 & 538 & 538 & 5,497 & 5,655 & 5,725 & 5,793 & 5,793 & 6,064 \\
\hline Supplies & 738 & 1,128 & 1,128 & 1,974 & 1,974 & 1,974 & 2,074 & 2,074 & 2,226 \\
\hline TOTALS & 10,816 & 11,206 & 12,540 & 16,277 & 17,667 & 16,670 & 16,838 & 18,070 & 18,493 \\
\hline
\end{tabular}


Table A-11. Space Requirements for Process Functions in LMFBR Oxide Fuel Fabrication and Refabrication Plants

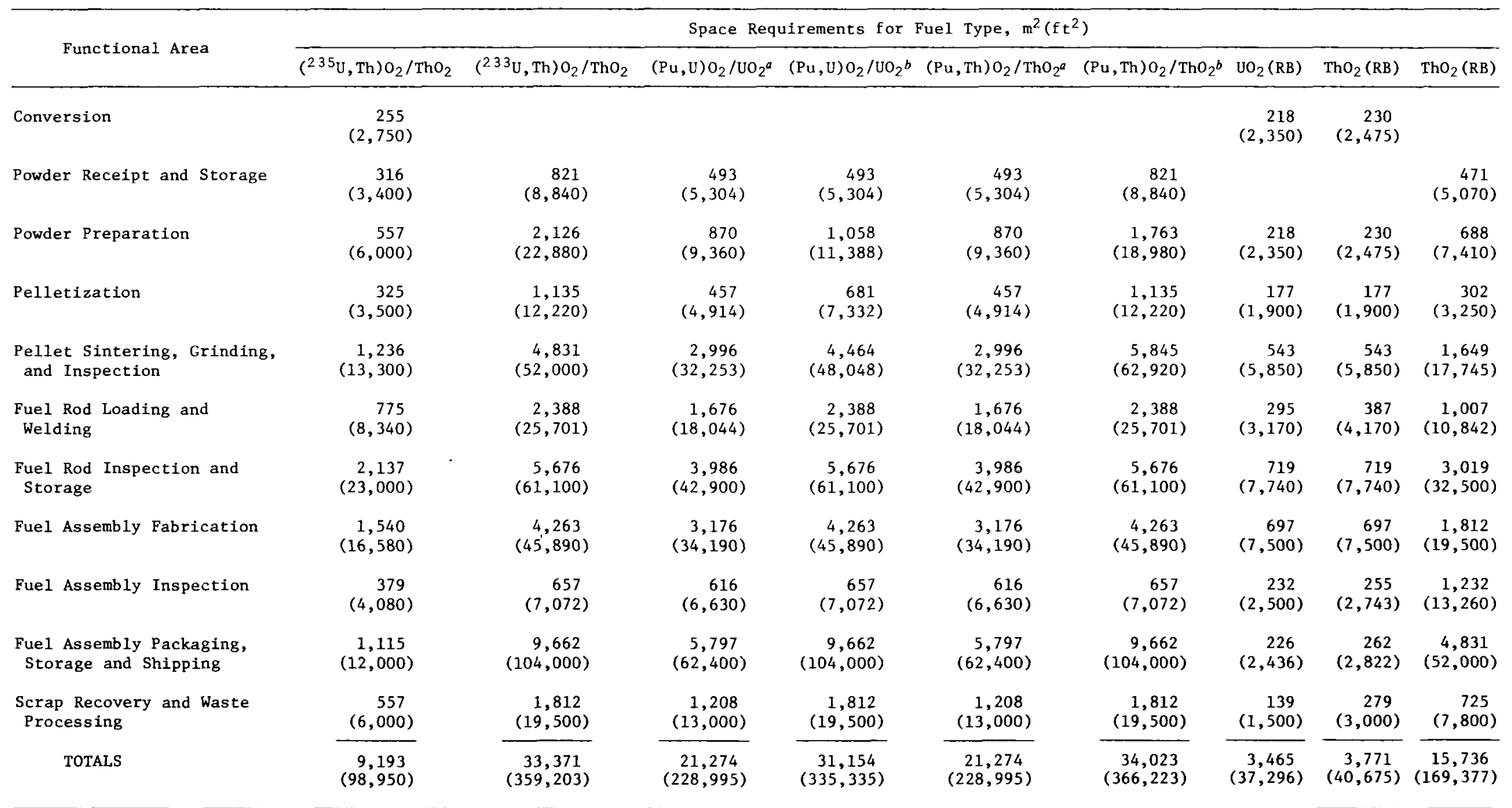


Table A-12. Facility Capital Costs for LMFBR Oxide Fuel Fabrication and Refabrication Plants

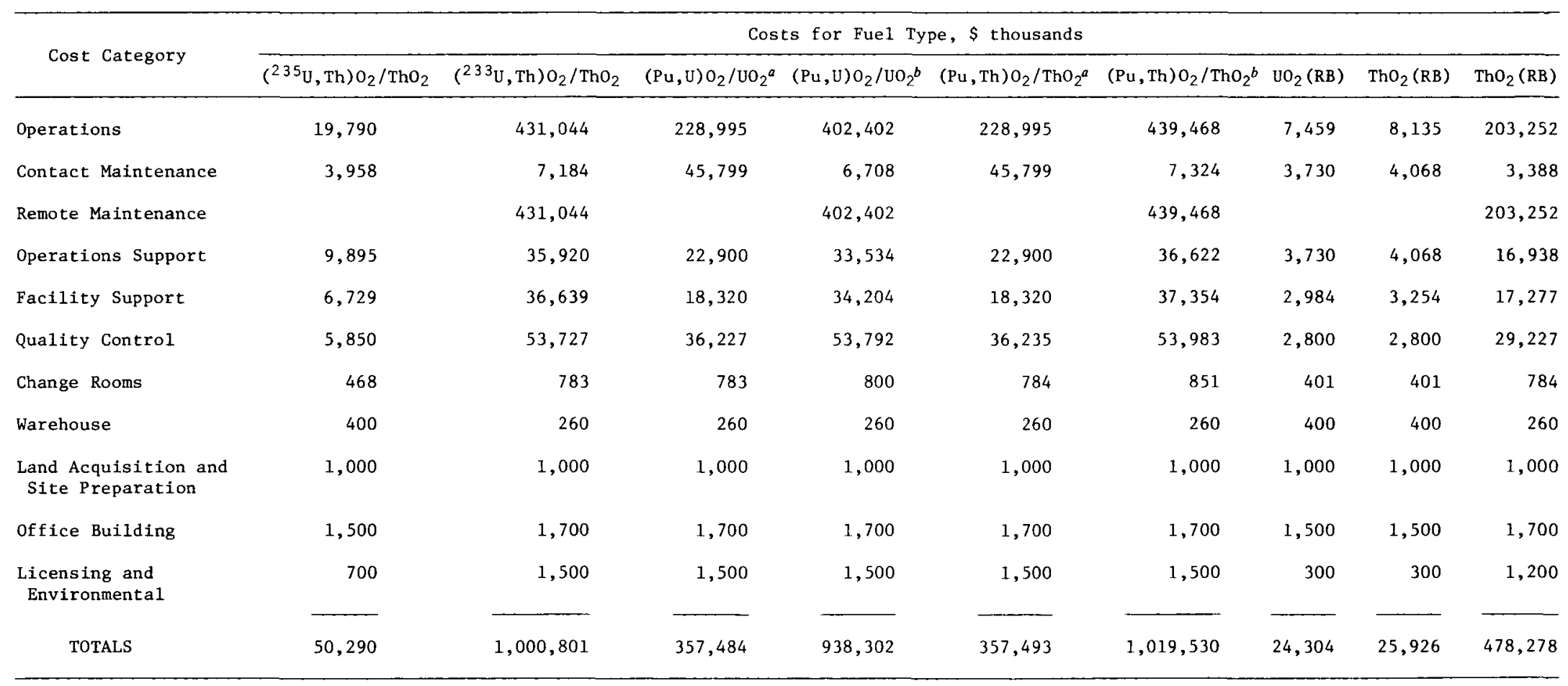


Table A-13. Equipment Capital Costs for LMFBR Oxide Fuel Fabrication and Refabrication Plants

\begin{tabular}{|c|c|c|c|c|c|c|c|c|c|}
\hline \multirow{2}{*}{ Cost Category } & \multicolumn{9}{|c|}{ Costs for Fue1 Type, $\$$ thousands } \\
\hline & $\left({ }^{235} \mathrm{U}, \mathrm{Th}\right) \mathrm{O}_{2} / \mathrm{ThO}_{2}$ & $\left({ }^{233} \mathrm{U}, \mathrm{Th}\right) \mathrm{O}_{2} / \mathrm{ThO}_{2}$ & $(\mathrm{Pu}, \mathrm{U}) \mathrm{O}_{2} / \mathrm{UO}_{2}{ }^{a}$ & $(\mathrm{Pu}, \mathrm{U}) \mathrm{O}_{2} / \mathrm{UO}_{2}{ }^{b}$ & $(\mathrm{Pu}, \mathrm{Th}) \mathrm{O}_{2} / \mathrm{ThO}_{2}{ }^{a}$ & $(\mathrm{Pu}, \mathrm{Th}) \mathrm{O}_{2} / \mathrm{ThO}_{2}{ }^{b}$ & $\mathrm{UO}_{2}(\mathrm{RB})$ & $\mathrm{ThO}_{2}(\mathrm{RB})$ & $\mathrm{ThO}_{2}(\mathrm{RB})$ \\
\hline Operations & 28,492 & 121,446 & 102,739 & 114,231 & 102,739 & 129,111 & 11,159 & 12,076 & 147,216 \\
\hline Contact Maintenance & 28,492 & & 82,739 & & 82,739 & & 11,159 & 12,076 & \\
\hline Remote Maintenance & & 111,446 & & 104,231 & & 119,111 & & & 127,216 \\
\hline Operations Support & 10,336 & 10,336 & 10,336 & 10,336 & 10,336 & 10,336 & 4,268 & 5,187 & 5,187 \\
\hline Facility Support & 10,685 & 41,792 & 31,027 & 39,087 & 31,027 & 44,667 & 5,580 & 6,038 & 47,706 \\
\hline Quality Control & 2,846 & 5,692 & 4,269 & 5,692 & 4,269 & 5,692 & 1,423 & 1,423 & 5,692 \\
\hline Warehouse & 600 & 780 & 780 & 780 & 780 & 780 & 60 & 60 & 780 \\
\hline TOTALS & 81,451 & 291,492 & 231,890 & 274,357 & 231,890 & 309,697 & 33,649 & 36,860 & 333,797 \\
\hline
\end{tabular}

Table A-14. Annual Operating Costs for LMFBR Oxide Fuel Fabrication and Refabrication Plants

\begin{tabular}{|c|c|c|c|c|c|c|c|c|c|}
\hline \multirow{2}{*}{ Cost Category } & \multicolumn{9}{|c|}{ Annual Costs for Fuel Type, $\$$ thousands } \\
\hline & $\left({ }^{235} \mathrm{U}, \mathrm{Th}\right) \mathrm{O}_{2} / \mathrm{ThO}_{2}$ & $\left({ }^{23}{ }^{3} \mathrm{U}, \mathrm{Th}\right) \mathrm{O}_{2} / \mathrm{ThO}_{2}$ & $(\mathrm{Pu}, \mathrm{U}) \mathrm{O}_{2} / \mathrm{UO}_{2}{ }^{a}$ & $(\mathrm{Pu}, \mathrm{U}) \mathrm{O}_{2} / \mathrm{UO}_{2}{ }^{b}$ & $(\mathrm{Pu}, \mathrm{Th}) \mathrm{O}_{2} / \mathrm{ThO}_{2}{ }^{a}$ & $(\mathrm{Pu}, \mathrm{Th}) \mathrm{O}_{2} / \mathrm{ThO}_{2}{ }^{b}$ & $\mathrm{UO}_{2}(\mathrm{RB})$ & $\mathrm{ThO}_{2}(\mathrm{RB})$ & $\mathrm{ThO}_{2}(\mathrm{RB})$ \\
\hline Personnel (Variable) & 12,354 & 18,873 & 18,257 & 19,196 & 18,462 & 19,308 & 10,355 & 10,355 & 19,081 \\
\hline Personnel (Fixed) & 2,611 & 5,312 & 5,070 & 5,295 & 5,102 & 5,295 & 2,611 & 2,611 & 5,102 \\
\hline Overhead & 177 & 177 & 177 & 177 & 177 & 177 & 177 & 177 & 177 \\
\hline Utilities & 569 & 2,037 & 1,620 & 1,917 & 1,917 & 2,164 & 239 & 239 & 2,037 \\
\hline TOTALS & 15,711 & 26,399 & 25,124 & 26,585 & 25,658 & 26,944 & 13,382 & 13,382 & 26,397 \\
\hline
\end{tabular}


Table A-15. Annual Materials Costs for LMFBR Oxide Fuel Fabrication and Refabrication

\begin{tabular}{|c|c|c|c|c|c|c|c|c|c|}
\hline \multirow{2}{*}{ Cost Category } & \multicolumn{9}{|c|}{ Annual Costs for Fuel Type, $\$$ thousands } \\
\hline & $\left({ }^{235} \mathrm{U}, \mathrm{Th}\right) \mathrm{O}_{2} / \mathrm{ThO}_{2}$ & $\left({ }^{233} \mathrm{U}, \mathrm{Th}\right) \mathrm{O}_{2} / \mathrm{ThO}_{2}$ & $(\mathrm{Pu}, \mathrm{U}) \mathrm{O}_{2} / \mathrm{UO}_{2}{ }^{\mathrm{a}}$ & $(\mathrm{Pu}, \mathrm{U}) \mathrm{O}_{2} / \mathrm{UO}_{2}^{b}$ & $(\mathrm{Pu}, \mathrm{Th}) \mathrm{O}_{2} / \mathrm{ThO}_{2}{ }^{a}$ & $(\mathrm{Pu}, \mathrm{Th}) \mathrm{O}_{2} / \mathrm{ThO}_{2}{ }^{\mathrm{b}}$ & $\mathrm{UO}_{2}(\mathrm{RB})$ & $\mathrm{ThO}_{2}(\mathrm{RB})$ & $\mathrm{ThO}_{2}(\mathrm{RB})$ \\
\hline Hardware & 70,709 & 65,270 & 59,962 & 59,962 & 65,270 & 65,270 & 30,914 & 34,101 & 31,478 \\
\hline Direct Materials & 7,709 & 7,117 & 7,330 & 7,330 & 7,282 & 7,282 & 476 & 476 & 440 \\
\hline Indirect Materials & 2,246 & 8,340 & 7,534 & 7,534 & 8,075 & 8,075 & 538 & . 551 & 494 \\
\hline Supplies & 1,128 & 1,974 & 1,974 & 1,974 & 2,074 & 2,074 & 1,128 & 1,128 & 1,128 \\
\hline TOTALS & 81,792 & 82,701 & 76,800 & 76,800 & 82,701 & 82,701 & 33,056 & 36,256 & 33,540 \\
\hline
\end{tabular}


Table A-16. Space Requirements for Process Functions in LMFBR Carbide Fuel Refabrication Plants

\begin{tabular}{|c|c|c|c|c|c|c|c|c|}
\hline \multirow{2}{*}{ Functional Area } & \multicolumn{8}{|c|}{ Space Requirements for Fuel Type, $\mathrm{m}^{2}\left(\mathrm{ft}^{2}\right)$} \\
\hline & $\left({ }^{233} \mathrm{U}, \mathrm{Th}\right) \mathrm{C} / \mathrm{ThC}$ & $(\mathrm{Pu}, \mathrm{U}) \mathrm{C} / \mathrm{UC}^{a}$ & $(\mathrm{Pu}, \mathrm{U}) \mathrm{C} / \mathrm{UC}^{b}$ & $(\mathrm{Pu}, \mathrm{Th}) \mathrm{C} / \mathrm{ThC}^{a}$ & $(\mathrm{Pu}, \mathrm{Th}) \mathrm{C} / \mathrm{ThC}^{b}$ & $\mathrm{UC}(\mathrm{RB})$ & ThC (RB) & ThC (RB) \\
\hline Conversion & & & & & & $\begin{array}{c}251 \\
(2,700)\end{array}$ & $\begin{array}{c}251 \\
(2,700)\end{array}$ & \\
\hline Powder Receipt and Storage & $\begin{array}{c}242 \\
(2,600)\end{array}$ & $\begin{array}{c}242 \\
(2,600)\end{array}$ & $\begin{array}{c}242 \\
(2,600)\end{array}$ & $\begin{array}{c}242 \\
(2,600)\end{array}$ & $\begin{array}{c}242 \\
(2,600)\end{array}$ & & & $\begin{array}{c}471 \\
(5,070)\end{array}$ \\
\hline Powder Preparation & $\begin{array}{c}1,329 \\
(14,300)\end{array}$ & $\begin{array}{c}1,063 \\
(11,440)\end{array}$ & $\begin{array}{c}1,329 \\
(14,300)\end{array}$ & $\begin{array}{c}1,063 \\
(11,440)\end{array}$ & $\begin{array}{c}1,329 \\
(14,300)\end{array}$ & $\begin{array}{c}251 \\
(2,700)\end{array}$ & $\begin{array}{c}251 \\
(2,700)\end{array}$ & $\begin{array}{c}1,147 \\
(12,350)\end{array}$ \\
\hline Pelletization & $\begin{array}{c}604 \\
(6,500)\end{array}$ & $\begin{array}{c}380 \\
(4,095)\end{array}$ & $\begin{array}{c}604 \\
(6,500)\end{array}$ & $\begin{array}{c}380 \\
(4,095)\end{array}$ & $\begin{array}{c}604 \\
(6,500)\end{array}$ & $\begin{array}{c}348 \\
(3,750)\end{array}$ & $\begin{array}{c}348 \\
(3,750)\end{array}$ & $\begin{array}{r}815 \\
(8,775)\end{array}$ \\
\hline $\begin{array}{l}\text { Pellet Sintering, Grinding, } \\
\text { and Inspection }\end{array}$ & $\begin{array}{c}3,563 \\
(38,350)\end{array}$ & $\begin{array}{c}2,304 \\
(24,798)\end{array}$ & $\begin{array}{c}3,563 \\
(38,350)\end{array}$ & $\begin{array}{c}2,304 \\
(24,798)\end{array}$ & $\begin{array}{c}3,563 \\
(38,350)\end{array}$ & $\begin{array}{c}945 \\
(10,175)\end{array}$ & $\begin{array}{c}945 \\
(10,175)\end{array}$ & $\begin{array}{r}1,736 \\
(18,688)\end{array}$ \\
\hline $\begin{array}{l}\text { Fuel Rod Loading and } \\
\text { Welding }\end{array}$ & $\begin{array}{c}2,541 \\
(27,352)\end{array}$ & $\begin{array}{c}1,580 \\
(17,004)\end{array}$ & $\begin{array}{c}2,332 \\
(25,103)\end{array}$ & $\begin{array}{c}1,789 \\
(19,253)\end{array}$ & $\begin{array}{c}2,541 \\
(27,352)\end{array}$ & $\begin{array}{c}338 \\
(3,640)\end{array}$ & $\begin{array}{c}338 \\
(3,640)\end{array}$ & $\begin{array}{c}1,209 \\
(13,013)\end{array}$ \\
\hline $\begin{array}{l}\text { Fue1 Rod Inspection and } \\
\text { Storage }\end{array}$ & $\begin{array}{c}3,623 \\
(39,000)\end{array}$ & $\begin{array}{c}2,355 \\
(25,350)\end{array}$ & $\begin{array}{c}3,019 \\
(32,500)\end{array}$ & $\begin{array}{c}2,415 \\
(26,000)\end{array}$ & $\begin{array}{c}3,623 \\
(39,000)\end{array}$ & $\begin{array}{c}557 \\
(6,000)\end{array}$ & $\begin{array}{c}557 \\
(6,000)\end{array}$ & $\begin{array}{r}4,710 \\
(50,700)\end{array}$ \\
\hline Fue1 Assembly Fabrication & $\begin{array}{c}3,780 \\
(40,690)\end{array}$ & $\begin{array}{c}2,693 \\
(28,990)\end{array}$ & $\begin{array}{c}3,539 \\
(38,090)\end{array}$ & $\begin{array}{c}2,814 \\
(30,290)\end{array}$ & $\begin{array}{c}3,780 \\
(40,690)\end{array}$ & $\begin{array}{c}810 \\
(8,720)\end{array}$ & $\begin{array}{c}903 \\
(9,720)\end{array}$ & $\begin{array}{r}4,394 \\
(47,294)\end{array}$ \\
\hline Fuel Assembly Inspection & $\begin{array}{c}657 \\
(7,072)\end{array}$ & $\begin{array}{c}616 \\
(6,630)\end{array}$ & $\begin{array}{c}657 \\
(7,072)\end{array}$ & $\begin{array}{c}616 \\
(6,630)\end{array}$ & $\begin{array}{c}657 \\
(7,072)\end{array}$ & $\begin{array}{c}253 \\
(2,720)\end{array}$ & $\begin{array}{c}253 \\
(2,720)\end{array}$ & $\begin{array}{r}657 \\
(7,072)\end{array}$ \\
\hline $\begin{array}{l}\text { Fuel Assembly Packaging, } \\
\text { Storage and Shipping }\end{array}$ & $\begin{array}{c}9,662 \\
(104,000)\end{array}$ & $\begin{array}{c}5,797 \\
(62,400)\end{array}$ & $\begin{array}{c}9,662 \\
(104,000)\end{array}$ & $\begin{array}{c}5,797 \\
(62,400)\end{array}$ & $\begin{array}{c}9,662 \\
(104,000)\end{array}$ & $\begin{array}{c}372 \\
(4,000)\end{array}$ & $\begin{array}{c}372 \\
(4,000)\end{array}$ & $\begin{array}{r}7,246 \\
(78,000)\end{array}$ \\
\hline $\begin{array}{l}\text { Scrap Recovery and Waste } \\
\text { Processing }\end{array}$ & $\begin{array}{c}2,174 \\
(23,400)\end{array}$ & $\begin{array}{c}1,449 \\
(15,600)\end{array}$ & $\begin{array}{c}2,174 \\
(23,400)\end{array}$ & $\begin{array}{c}1,449 \\
(15,600)\end{array}$ & $\begin{array}{c}2,174 \\
(23,400)\end{array}$ & $\begin{array}{c}279 \\
(3,000)\end{array}$ & $\begin{array}{c}372 \\
(4,000)\end{array}$ & $\begin{array}{c}1,208 \\
(13,000)\end{array}$ \\
\hline TOTALS & $\begin{array}{c}28,174 \\
(303,264)\end{array}$ & $\begin{array}{c}18,479 \\
(198,907)\end{array}$ & $\begin{array}{c}27,120 \\
(291,915)\end{array}$ & $\begin{array}{c}18,869 \\
(203,106)\end{array}$ & $\begin{array}{c}28,174 \\
(303,264)\end{array}$ & $\begin{array}{c}4,404 \\
(47,405)\end{array}$ & $\begin{array}{c}4,404 \\
(47,405)\end{array}$ & $\begin{array}{c}23,594 \\
(253,962)\end{array}$ \\
\hline
\end{tabular}


Table A-17. Facility Capital costs for LMFBR Carbide Fuel Refabrication Plants

\begin{tabular}{|c|c|c|c|c|c|c|c|c|}
\hline \multirow{2}{*}{ Cost Category } & \multicolumn{8}{|c|}{ Costs for Fuel Type, $\$$ thousands } \\
\hline & $\left({ }^{23}{ }^{3} \mathrm{U}, \mathrm{Th}\right) \mathrm{C} / \mathrm{ThC}$ & $(\mathrm{Pu}, \mathrm{U}) \mathrm{C} / \mathrm{UC}^{a}$ & $(\mathrm{Pu}, \mathrm{U}) \mathrm{C} / \mathrm{UC}^{b}$ & $(\mathrm{Pu}, \mathrm{Th}) \mathrm{C} / \mathrm{ThC}^{a}$ & $(\mathrm{Pu}, \mathrm{Th}) \mathrm{C} / \mathrm{ThC}^{b}$ & $\mathrm{UC}(\mathrm{RB})$ & ThC (RB) & ThC (RB) \\
\hline Operations & 454,896 & 248,634 & 437,873 & 253,883 & 454,896 & 14,222 & 14,822 & 380,943 \\
\hline Contact Maintenance & 6,066 & 39,783 & 5,840 & 40,622 & 6,066 & 4,740 & 4,940 & 5,080 \\
\hline Remote Maintenance & 363,917 & & 350,298 & & 363,917 & & & 304,754 \\
\hline Operations Support & 30,326 & 19,891 & 29,192 & 20,311 & 30,326 & 4,740 & 4,940 & 25,397 \\
\hline Facility Support & 30,934 & 11,935 & 29,775 & 12,186 & 30,934 & 3,792 & 3,972 & 25,904 \\
\hline Quality Control & 57,325 & 36,157 & 57,287 & 36,195 & 57,325 & 4,200 & 4,200 & 35,935 \\
\hline Change Rooms & 809 & 764 & 799 & 774 & 809 & 401 & 401 & 809 \\
\hline Warehouse & 260 & 260 & 260 & 260 & 260 & 400 & 400 & 260 \\
\hline $\begin{array}{l}\text { Land Acquisition and } \\
\text { Site Preparation }\end{array}$ & 1,000 & 1,000 & 1,000 & 1,000 & 1,000 & 1,000 & 1,000 & 1,000 \\
\hline Office Buflding & 1,700 & 1,700 & 1,700 & 1,700 & 1,700 & 1,500 & 1,500 & 1,700 \\
\hline $\begin{array}{l}\text { Licensing and } \\
\text { Environmental }\end{array}$ & 1,500 & 1,500 & 1,500 & 1,500 & 1,500 & 300 & 300 & 1,200 \\
\hline TOTALS & 948,733 & 361,624 & 915,524 & 368,431 & 948,733 & 35,295 & 36,475 & 782,982 \\
\hline
\end{tabular}


Table A-18. Equipment Capital Costs for LMFBR Carbide Fuel Refabrication Plants

\begin{tabular}{|c|c|c|c|c|c|c|c|c|}
\hline \multirow{2}{*}{ Cost Category } & \multicolumn{8}{|c|}{ Costs for Fuel Type, $\$$ thousands } \\
\hline & $\left({ }^{23}{ }^{3} \mathrm{U}, \mathrm{Th}\right) \mathrm{C} / \mathrm{ThC}$ & $(\mathrm{Pu}, \mathrm{U}) \mathrm{C} / \mathrm{UC}^{a}$ & $(\mathrm{Pu}, \mathrm{U}) \mathrm{C} / \mathrm{UC}^{b}$ & $(\mathrm{Pu}, \mathrm{Th}) \mathrm{C} / \mathrm{ThC}^{a}$ & $(\mathrm{Pu}, \mathrm{Th}) \mathrm{C} / \mathrm{ThC}^{b}$ & $\mathrm{UC}(\mathrm{RB})$ & ThC (RB) & $\operatorname{ThC}(\mathrm{RB})$ \\
\hline Operations & 122,686 & 108,360 & 120,886 & 109,910 & 122,886 & 18,887 & 20,247 & 111,634 \\
\hline Contact Maintenance & & 88,360 & & 89,910 & & 18,887 & 20,247 & \\
\hline Remote Maintenance & 112,686 & & 110,886 & & 112,886 & & & 91,634 \\
\hline Operations Support & 10,336 & 10,336 & 10,336 & 10,336 & 10,336 & 7,083 & 7,593 & 7,593 \\
\hline Facility Support & 42,257 & 33,135 & 41,582 & 33,716 & 42,332 & 9,444 & 10,124 & 34,363 \\
\hline Quality Control & 5,692 & 4,269 & 5,692 & 4,269 & 5,692 & 2,135 & 2,846 & 5,692 \\
\hline Warehouse & 780 & 780 & 780 & 780 & 780 & 60 & 60 & 780 \\
\hline TOTALS & 294,437 & 245,240 & 290,162 & 248,921 & 294,912 & 56,496 & $\cdot 61,117$ & 251,696 \\
\hline
\end{tabular}


Table A-19. Annual Operating Costs for LMFBR Carbide Fuel Refabrication Plants

\begin{tabular}{|c|c|c|c|c|c|c|c|c|}
\hline \multirow{2}{*}{ Cost Category } & \multicolumn{8}{|c|}{ Annual Costs for Fuel Type, $\$$ thousands } \\
\hline & $\left({ }^{23}{ }^{3} \mathrm{U}, \mathrm{Th}\right) \mathrm{C} / \mathrm{ThC}$ & $(\mathrm{Pu}, \mathrm{U}) \mathrm{C} / \mathrm{UC}^{a}$ & $(\mathrm{Pu}, \mathrm{U}) \mathrm{C} / \mathrm{UC}^{b}$ & $(\mathrm{Pu}, \mathrm{Th}) \mathrm{C} / \mathrm{ThC}^{a}$ & $(\mathrm{Pu}, \mathrm{Th}) \mathrm{C} / \mathrm{ThC}^{b}$ & $\mathrm{UC}(\mathrm{RB})$ & ThC (RB) & ThC (RB) \\
\hline Personne1 (Variable) & 17,637 & 16,504 & 17,377 & 16,794 & 17,637 & 10,355 & 10,355 & 19,799 \\
\hline Personnel (Fixed) & 7,264 & 7,086 & 7,229 & 7,086 & 7,264 & 2,611 & 2,611 & 5,102 \\
\hline Overhead & 177 & 177 & 177 & 177 & 177 & 177 & 177 & 177 \\
\hline Utilities & 2,058 & 1,713 & 2,028 & 1,739 & 2,061 & 239 & 239 & 2,058 \\
\hline TOTALS & 27,136 & 25,480 & 26,811 & 25,796 & 27,139 & 13,382 & 13,382 & 27,136 \\
\hline
\end{tabular}

Table A-20. Annual Materials Costs for LMFBR Carbide Fuel Refabrication

\begin{tabular}{|c|c|c|c|c|c|c|c|c|}
\hline \multirow{2}{*}{ Cost Category } & \multicolumn{8}{|c|}{ Annual Costs for Fuel Type, $\$$ thousands } \\
\hline & $\left({ }^{23}{ }^{3} \mathrm{U}, \mathrm{Th}\right) \mathrm{C} / \mathrm{ThC}$ & $(\mathrm{Pu}, \mathrm{U}) \mathrm{C} / \mathrm{UC}^{a}$ & $(\mathrm{Pu}, \mathrm{U}) \mathrm{C} / \mathrm{UC}^{b}$ & $(\mathrm{Pu}, \mathrm{Th}) \mathrm{C} / \mathrm{ThC}^{a}$ & $(\mathrm{Pu}, \mathrm{Th}) \mathrm{C} / \mathrm{ThC}^{b}$ & $\mathrm{UC}(\mathrm{RB})$ & ThC (RB) & ThC (RB) \\
\hline Hardware & 49,968 & 41,122 & 41,122 & 49,968 & 49,968 & 25,355 & 32,505 & 30,005 \\
\hline Direct Materials & 9,818 & 11,254 & 11,254 & 9,818 & 9,818 & 2,718 & 2,718 & 2,509 \\
\hline Indirect Materials & 8,666 & 8,832 & 8,832 & 8,666 & 8,666 & 1,359 & 1,659 & 1,478 \\
\hline Supplies & 1,974 & 1,974 & 1,974 & 1,974 & 1,974 & 1,128 & 1,128 & 1,128 \\
\hline TOTALS & 70,426 & 63,182 & 63,182 & 70,426 & 70,426 & 30,560 & 38,010 & 35,120 \\
\hline
\end{tabular}


Table A-21. Space Requirements for Process Functions in LMFBR Metal Fuel Refabrication Plants

\begin{tabular}{|c|c|c|c|c|c|c|c|c|}
\hline \multirow{2}{*}{ Functional Area } & \multicolumn{8}{|c|}{ Space Requirements for Fuel Type, $\mathrm{m}^{2}\left(\mathrm{ft} \mathrm{t}^{2}\right)$} \\
\hline & ${ }^{23}{ }^{3} \mathrm{U}, \mathrm{Th} / \mathrm{Th}$ & $\mathrm{Pu}, \mathrm{U}, \mathrm{Zr} / \mathrm{U}^{a}$ & $\mathrm{Pu}, \mathrm{U}, \mathrm{Zr} / \mathrm{U}^{b}$ & $\mathrm{Pu}, \mathrm{Th} / \mathrm{Th}^{a}$ & $\mathrm{Pu}, \mathrm{Th} / \mathrm{Th}^{b}$ & $\mathrm{U}(\mathrm{RB})$ & $\operatorname{Th}(\mathrm{RB})$ & Th (RB) \\
\hline Conversion & & & & & & $\begin{array}{c}276 \\
(2,975)\end{array}$ & $\begin{array}{c}293 \\
(3,150)\end{array}$ & \\
\hline Powder Receipt and Storage & $\begin{array}{c}725 \\
(7,800)\end{array}$ & $\begin{array}{c}386 \\
(4,160)\end{array}$ & $\begin{array}{c}580 \\
(6,240)\end{array}$ & $\begin{array}{c}483 \\
(5,200)\end{array}$ & $\begin{array}{c}725 \\
(7,800)\end{array}$ & & & $\begin{array}{c}471 \\
(5,070)\end{array}$ \\
\hline $\begin{array}{l}\text { Powder Preparation and } \\
\text { Reduction }\end{array}$ & $\begin{array}{c}2,319 \\
(24,960)\end{array}$ & $\begin{array}{c}1,075 \\
(11,570)\end{array}$ & $\begin{array}{c}1,172 \\
(12,610)\end{array}$ & $\begin{array}{c}2,174 \\
(23,400)\end{array}$ & $\begin{array}{c}2,319 \\
(24,960)\end{array}$ & $\begin{array}{c}276 \\
(2,975)\end{array}$ & $\begin{array}{c}293 \\
(3,150)\end{array}$ & $\begin{array}{c}839 \\
(9,035)\end{array}$ \\
\hline Slug Preparation & $\begin{array}{c}2,488 \\
(26,780)\end{array}$ & $\begin{array}{c}1,787 \\
(19,240)\end{array}$ & $\begin{array}{c}2,488 \\
(26,780)\end{array}$ & $\begin{array}{c}1,787 \\
(19,240)\end{array}$ & $\begin{array}{c}2,488 \\
(26,780)\end{array}$ & $\begin{array}{c}929 \\
(10,000)\end{array}$ & $\begin{array}{c}929 \\
(10,000)\end{array}$ & $\begin{array}{c}2,210 \\
(23,790)\end{array}$ \\
\hline $\begin{array}{l}\text { Fuel Rod Loading and } \\
\text { Welding }\end{array}$ & $\begin{array}{c}2,041 \\
(21,970)\end{array}$ & $\begin{array}{c}1,330 \\
(14,313)\end{array}$ & $\begin{array}{c}1,915 \\
(20,618)\end{array}$ & $\begin{array}{c}1,455 \\
(15,665)\end{array}$ & $\begin{array}{c}2,041 \\
(21,970)\end{array}$ & $\begin{array}{c}338 \\
(3,640)\end{array}$ & $\begin{array}{c}338 \\
(3,640)\end{array}$ & $\begin{array}{c}1,209 \\
(13,013)\end{array}$ \\
\hline $\begin{array}{l}\text { Fuel Rod Inspection and } \\
\text { Storage }\end{array}$ & $\begin{array}{c}3,623 \\
(39,000)\end{array}$ & $\begin{array}{c}2,114 \\
(22,750)\end{array}$ & $\begin{array}{c}3,019 \\
(32,500)\end{array}$ & $\begin{array}{c}2,415 \\
(26,000)\end{array}$ & $\begin{array}{c}3,623 \\
(39,000)\end{array}$ & $\begin{array}{c}557 \\
(6,000)\end{array}$ & $\begin{array}{c}557 \\
(6,000)\end{array}$ & $\begin{array}{c}4,710 \\
(50,700)\end{array}$ \\
\hline Fuel Assembly Fabrication & $\begin{array}{c}3,780 \\
(40,690)\end{array}$ & $\begin{array}{c}2,184 \\
(23,504)\end{array}$ & $\begin{array}{c}2,848 \\
(30,654)\end{array}$ & $\begin{array}{c}2,814 \\
(30,290)\end{array}$ & $\begin{array}{c}3,780 \\
(40,690)\end{array}$ & $\begin{array}{c}810 \\
(8,720)\end{array}$ & $\begin{array}{c}903 \\
(9,790)\end{array}$ & $\begin{array}{c}4,394 \\
(47,294)\end{array}$ \\
\hline Fuel Assembly Inspection & $\begin{array}{c}657 \\
(7,072)\end{array}$ & $\begin{array}{c}616 \\
(6,630)\end{array}$ & $\begin{array}{c}657 \\
(7,072)\end{array}$ & $\begin{array}{c}616 \\
(6,630)\end{array}$ & $\begin{array}{c}657 \\
(7,072)\end{array}$ & $\begin{array}{c}253 \\
(2,720)\end{array}$ & $\begin{array}{c}253 \\
(2,720)\end{array}$ & $\begin{array}{c}657 \\
(7,072)\end{array}$ \\
\hline $\begin{array}{l}\text { Fuel Assembly Packaging, } \\
\text { Storage, and Shipping }\end{array}$ & $\begin{array}{c}9,662 \\
(104,000)\end{array}$ & $\begin{array}{c}5,797 \\
(62,400)\end{array}$ & $\begin{array}{c}9,662 \\
(104,000)\end{array}$ & $\begin{array}{c}5,797 \\
(62,400)\end{array}$ & $\begin{array}{c}9,662 \\
(104,000)\end{array}$ & $\begin{array}{c}372 \\
(4,000)\end{array}$ & $\begin{array}{c}743 \\
(8,000)\end{array}$ & $\begin{array}{c}7,246 \\
(78,000)\end{array}$ \\
\hline $\begin{array}{l}\text { Scrap Recovery and Waste } \\
\text { Processing }\end{array}$ & $\begin{array}{r}2,415 \\
(26,000) \\
\end{array}$ & $\begin{array}{r}1,691 \\
(18,200) \\
\end{array}$ & $\begin{array}{r}2,415 \\
(26,000) \\
\end{array}$ & $\begin{array}{r}1,691 \\
(18,200) \\
\end{array}$ & $\begin{array}{r}2,415 \\
(26,000) \\
\end{array}$ & $\begin{array}{r}372 \\
(4,000) \\
\end{array}$ & $\begin{array}{r}557 \\
(6,000) \\
\end{array}$ & $\begin{array}{c}1,208 \\
(13,000) \\
\end{array}$ \\
\hline TOTALS & $\begin{array}{c}27,710 \\
(298,272)\end{array}$ & $\begin{array}{c}17,441 \\
(182,767)\end{array}$ & $\begin{array}{c}24,756 \\
(266,474)\end{array}$ & $\begin{array}{c}19,233 \\
(207,025)\end{array}$ & $\begin{array}{c}27,710 \\
(298,272)\end{array}$ & $\begin{array}{c}4,183 \\
(45,030)\end{array}$ & $\begin{array}{c}4,866 \\
(52,380)\end{array}$ & $\begin{array}{c}22,945 \\
(246,974)\end{array}$ \\
\hline
\end{tabular}


Table A-22. Facility Capital Costs for LMFBR Metal

Fuel Refabrication Plants

\begin{tabular}{|c|c|c|c|c|c|c|c|c|}
\hline \multirow{2}{*}{ Cost Category } & \multicolumn{8}{|c|}{ Costs for Fuel Type, $\$$ thousands } \\
\hline & $2{ }^{3}{ }^{3} \mathrm{U}, \mathrm{Th} / \mathrm{Th}$ & $\mathrm{Pu}, \mathrm{U}, \mathrm{Zr} / \mathrm{U}^{a}$ & $\mathrm{Pu}, \mathrm{U}, \mathrm{2r} / \mathrm{U}^{b}$ & $\mathrm{Pu}, \mathrm{Th} / \mathrm{Th}^{a}$ & $\mathrm{PL}, \mathrm{Th} / \mathrm{Th}^{b}$ & $\mathrm{U}(\mathrm{RB})$ & $\operatorname{Th}(\mathrm{RB})$ & $\operatorname{Th}(R B)$ \\
\hline Operations & 447,408 & 228,459 & 399,711 & 258,781 & 447,408 & 13,509 & 15,714 & 370,461 \\
\hline Contact MaIntenance & 5,966 & 36,553 & 5,330 & 41,405 & 5,966 & 4,503 & 5,238 & 4,940 \\
\hline Remote Maintenance & 357,926 & & 319,769 & & 357,926 & & & 296,369 \\
\hline Operations Support & 29,827 & 18,277 & 26,647 & 20,703 & 29,827 & 4,503 & 5,238 & 24,697 \\
\hline Facility Support & 30,424 & 14,621 & 27,180 & 16,562 & 30,424 & 3,602 & 4,190 & 25,191 \\
\hline Quality Control & 57,570 & 36,398 & 57,545 & 36,463 & 57,570 & 4,200 & 4,200 & 36,570 \\
\hline Change Rooms & 874 & 828 & 868 & 846 & 874 & 401 & 401 & 874 \\
\hline Warehouse & 260 & 260 & 260 & 260 & 260 & 400 & 400 & 260 \\
\hline $\begin{array}{l}\text { Land Acquisition and } \\
\text { Site Preparation }\end{array}$ & 1,000 & 1,000 & 1,000 & 1,000 & 1,000 & 1,000 & 1,000 & 1,000 \\
\hline Office Building & 1,700 & 1,700 & 1,700 & 1,700 & 1,700 & 1,500 & 1,500 & 1,700 \\
\hline $\begin{array}{l}\text { Licensing and } \\
\text { Environmental }\end{array}$ & 1,500 & 1,500 & 1,500 & 1,500 & 1,500 & 300 & 300 & 1,200 \\
\hline TOTALS & 934,455 & 339,596 & 841,510 & 379,220 & 934,455 & 33,918 & 38,181 & 763,262 \\
\hline
\end{tabular}

Table A-23. Equipment Capital Costs for LMFBR Metal Fuel Refabrication Plants

\begin{tabular}{|c|c|c|c|c|c|c|c|c|}
\hline \multirow{2}{*}{ Cost Category } & \multicolumn{8}{|c|}{ Costs for Fuel Type, $\$$ thousands } \\
\hline & ${ }^{23}{ }^{3} \mathrm{U}, \mathrm{Th} / \mathrm{Th}$ & $\mathrm{Pu}, \mathrm{U}, \mathrm{Zr} / \mathrm{U}^{a}$ & $\mathrm{Pu}, \mathrm{U}, \mathrm{Zr} / \mathrm{U}^{b}$ & $\mathrm{Pu}, \mathrm{Th} / \mathrm{Th}^{\circ}$ & $\mathrm{Pu}, \mathrm{Th} / \mathrm{Th}^{b}$ & $U(R B)$ & $\operatorname{Th}(\mathrm{RB})$ & $\operatorname{Th}(\mathrm{RB})$ \\
\hline Operations & 108,070 & 90,500 & 97,960 & 97,580 & 108,070 & 10,260 & 12,140 & 96,510 \\
\hline Contact Maintenance & & 70,500 & & 77,580 & & 10,260 & 12,140 & \\
\hline Remote Maintenance & 98,070 & & 87,960 & & 98,070 & & & 76,510 \\
\hline Operations Support & 10,336 & 10,336 & 10,336 & 10,336 & 10,336 & 3,848 & 4,553 & 4,553 \\
\hline Facility Support & 36,776 & 26,438 & 32,985 & 29,093 & 36,776 & 5,130 & 6,070 & 28,691 \\
\hline Quality Control & 5,692 & 4,269 & 5,692 & 4,269 & 5,692 & 2,135 & 2,846 & 5,692 \\
\hline Warehouse & 780 & 780 & 780 & 780 & 780 & 60 & 60 & 780 \\
\hline TOTALS & 259,724 & 202,823 & 235,713 & 219,638 & 259,724 & 31,693 & 37,809 & 212,736 \\
\hline
\end{tabular}


Table A-24. Annual Operating Costs for LMFBR Metal Fuel Refabrication Plants

\begin{tabular}{|c|c|c|c|c|c|c|c|c|}
\hline \multirow{2}{*}{ Cost Category } & \multicolumn{8}{|c|}{ Costs for Fuel Type, $\$$ thousands } \\
\hline & $23^{3} \mathrm{U}, \mathrm{Th} / \mathrm{Th}$ & $\mathrm{Pu}, \mathrm{U}, \mathrm{Zr} / \mathrm{U}^{e}$ & $\mathrm{Pu}, \mathrm{U}, \mathrm{Zr} / \mathrm{U}^{b}$ & $\mathrm{Pu}, \mathrm{Th} / \mathrm{Th}^{e}$ & $\mathrm{Pu}, \mathrm{Th} / \mathrm{Th}^{b}$ & $\mathrm{U}(\mathrm{RB})$ & $\operatorname{Th}(\mathrm{RB})$ & $\operatorname{Th}(\mathrm{RB})$ \\
\hline Personnel (Variable) & 19,432 & 18,299 & 19,289 & 18,733 & 19,432 & 10,355 & 10,355 & 21,661 \\
\hline Personnel (F1xed) & 7,331 & 7,153 & 7,299 & 7,219 & 7,331 & 2,611 & 2,611 & 5,102 \\
\hline Overhead & 177 & 177 & 177 & 177 & 177 & 177 & 177 & 177 \\
\hline Utilities & 1,815 & 1,417 & 1,647 & 1,535 & 1,815 & 239 & 239 & 1,819 \\
\hline TOTALS & 28,755 & 27,046 & 28,412 & 27,664 & 28,755 & 13,382 & 13,382 & 28,759 \\
\hline
\end{tabular}

Table A-25. Annual Materials Costs for LMFBR Metal Fuel Refabrication

\begin{tabular}{|c|c|c|c|c|c|c|c|c|}
\hline \multirow{2}{*}{ Cost Category } & \multicolumn{8}{|c|}{ Costs for Fuel Type, $\$$ thousands } \\
\hline & ${ }^{23}{ }^{3} \mathrm{U}, \mathrm{Th} / \mathrm{Th}$ & $\mathrm{Pu}, \mathrm{U}, \mathrm{Zr} / \mathrm{U}^{a}$ & $\mathrm{Pu}, U, Z r / v^{b}$ & $\mathrm{Pu}, \mathrm{Th} / \mathrm{Th}^{a}$ & $\mathrm{Pu}, \mathrm{Th} / \mathrm{Th}^{b}$ & $U(R B)$ & $\operatorname{Th}(R B)$ & Th (RB) \\
\hline Hardware & 40,483 & 33,849 & 33,849 & 40,483 & 40,483 & 17,441 & 26,811 & 24,749 \\
\hline Direct Materials & 19,454 & 23,971 & 23,971 & 19,454 & 19,454 & 6,431 & 6,774 & 6,231 \\
\hline Indirect Materials & 9,235 & 11,496 & 11,496 & 9,235 & 9,235 & 3,215 & 3,387 & 3,115 \\
\hline Supplies & 1,974 & 1,974 & 1,974 & 1,974 & 1,974 & 1,128 & 1,128 & 1,128 \\
\hline TOTALS & 71,146 & 71,290 & 71,290 & 71,146 & 71,146 & 28,215 & 38,100 & 35,223 \\
\hline
\end{tabular}


Appendix B

SUMMARY OF CAPITAL, OPERATING, AND

MATERIALS COSTS ESTIMATES FOR

HTGR FUELS 
Table B.1. July 1978 HTGR Capital Cost Increment Estimates for HTGR Fuels (2 MT/day HM plant)

\begin{tabular}{|c|c|c|c|c|c|c|c|c|c|c|}
\hline \multirow{2}{*}{ Item } & \multirow{2}{*}{$\begin{array}{l}\text { LEU } \\
\text { Fab. }\end{array}$} & \multirow{2}{*}{$\begin{array}{l}\text { MEU } \\
\text { Current } \\
\text { Fab. }\end{array}$} & \multirow{2}{*}{$\begin{array}{l}\text { MEU } \\
\text { Optimized } \\
\text { Fab. }\end{array}$} & \multicolumn{2}{|c|}{ MEU/Th } & \multirow{2}{*}{$\begin{array}{l}\text { MEU-233/Th } \\
\text { Refab. }\end{array}$} & \multirow{2}{*}{$\begin{array}{l}\text { Pu/Th } \\
\text { Refab. }\end{array}$} & \multirow{2}{*}{$\begin{array}{l}\text { HEU/Th } \\
\text { Reference } \\
\text { Fab. }\end{array}$} & \multirow{2}{*}{$\begin{array}{l}\text { Reference } \\
\text { Refab. } \\
\text { 23R/25R }\end{array}$} & \multirow{2}{*}{$\begin{array}{l}\text { HEU-233/Th } \\
\text { Refab. }\end{array}$} \\
\hline & & & & Fab. & Refab. & & & & & \\
\hline $\mathrm{U}, \mathrm{Pu}(\mathrm{kg} / \mathrm{FE})$ & 4.88 & 3.09 & 2.62 & 2.84 & 4.46 & 3.99 & 0.84 & 0.74 & $0.65 / 1.24$ & $0.56 / 0.63$ \\
\hline Th, U/Th (kg/FE) & & $\underline{2.49}$ & 3.5 & 4.11 & 4.11 & 7.14 & $\underline{4.59}$ & 11.24 & 11.24 & 13.5 \\
\hline Total HM $(\mathrm{kg} / \mathrm{FE})$ & 4.88 & 5.58 & 6.12 & 6.95 & 8.57 & 11.13 & 5.43 & 11.98 & $11.89 / 13 / 01$ & $14 / 06 / 14.13$ \\
\hline $\mathrm{C}: \mathrm{HM}$ & 450 & 385 & 348 & 295 & 240 & 194 & 375 & 169 & $170 / 162$ & 143 \\
\hline Plant capacity $(\mathrm{FE} / \mathrm{yr})$ & 106,557 & 93,109 & 84,967 & 74,820 & 56,075 & 43,127 & 88,398 & 43,406 & 40,370 & 34,043 \\
\hline $\begin{array}{l}\text { Adjusted Contents: } \\
\text { Fissile }(\mathrm{kg} / \mathrm{FE}) \\
\text { Fertile }(\mathrm{kg} / \mathrm{FE})\end{array}$ & & & & $\begin{array}{l}1.93 \\
5.02\end{array}$ & $\begin{array}{l}3.55 \\
5.02\end{array}$ & & & & & \\
\hline $\begin{array}{l}\text { Capacity factors: }:^{b} \\
\text { Fabrication } \\
\quad \mathrm{X}_{\mathrm{u}}(\mathrm{U}+\mathrm{Th}) / \mathrm{x}_{\mathrm{o}}(\mathrm{U}+\mathrm{Th})=\mathrm{C}_{\mathrm{E}}\end{array}$ & 1.088 & 0.874 & 0.844 & 0.939 & & & & 1 & & \\
\hline $\begin{array}{l}\text { Refabrication } \\
\mathrm{X}_{\mathrm{u}}(\mathrm{U}) / \mathrm{X}_{\mathrm{O}}(\mathrm{U})=\mathrm{C}_{\mathrm{E}} \\
\mathrm{X}_{\mathrm{U}}(\mathrm{FE}) / \mathrm{X}_{\mathrm{O}}(\mathrm{FE})=\mathrm{C}_{\mathrm{F}}\end{array}$ & 2.455 & 2.147 & 1.957 & 1.724 & $\begin{array}{l}4.44 \\
1.389\end{array}$ & $\begin{array}{l}5.7 \\
1.068\end{array}$ & $\begin{array}{l}1.2 \\
2.190\end{array}$ & 1 & $\begin{array}{l}1 \\
1\end{array}$ & $\begin{array}{l}0.873 \\
0.843\end{array}$ \\
\hline $\begin{array}{l}\text { Cost multipliers }{ }^{b} \\
\text { Equipment } \\
\text { Fabrication }\left(R_{E}\right)\end{array}$ & 1.604 & 1.563 & 1.470 & 1.369 & & & & 1 & & \\
\hline $\begin{array}{l}\text { Refabrication }\left(R_{E}\right) \\
\text { Facilities }\left(R_{F}\right)\end{array}$ & 1.714 & 1.582 & 1.496 & 1.387 & $\begin{array}{l}1.624 \\
1.300\end{array}$ & $\begin{array}{l}1.621 \\
1.054\end{array}$ & $\begin{array}{l}1.62 \\
1.872\end{array}$ & 1 & $\begin{array}{l}1 \\
1\end{array}$ & $\begin{array}{l}0.905 \\
0.872\end{array}$ \\
\hline $\begin{array}{l}\text { Capital estimates } \\
\text { Facility }\end{array}$ & & & & & & & & & & \\
\hline $\begin{array}{l}\text { Calculated } \\
\text { Adjustment }\end{array}$ & $\begin{array}{l}87 \\
-\end{array}$ & 81 & $\begin{array}{l}76 \\
-\end{array}$ & $\begin{array}{r}71 \\
-\end{array}$ & $\begin{array}{l}395 \\
- \\
\end{array}$ & $\begin{array}{r}320 \\
-\end{array}$ & $\begin{array}{r}569 \\
-\ldots\end{array}$ & & & 265 \\
\hline Final $\left(\$ 10^{6}\right)$ & 87 & 81 & 76 & 71 & 395 & 320 & 569 & 51 & 304 & 265 \\
\hline $\begin{array}{l}\text { Equipment } \\
\text { Calculated } \\
\text { Adjustment }\end{array}$ & 266 & 260 & 244 & 227 & 809 & 807 & 807 & & & 450 \\
\hline Final $\left(\$ 10^{6}\right)$ & 266 & 260 & 244 & 227 & 809 & 807 & 807 & 166 & 498 & 450 \\
\hline
\end{tabular}

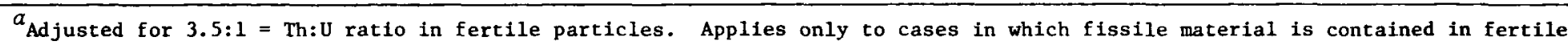
particles.

$b_{\text {Subscript }} E$ refers to equipment and subscript $F$ refers to facility. 
Table B.2. July 1978 HTGR Operating Cost Increment Estimates for HTGR Fuels (2 MT/day HM plant)

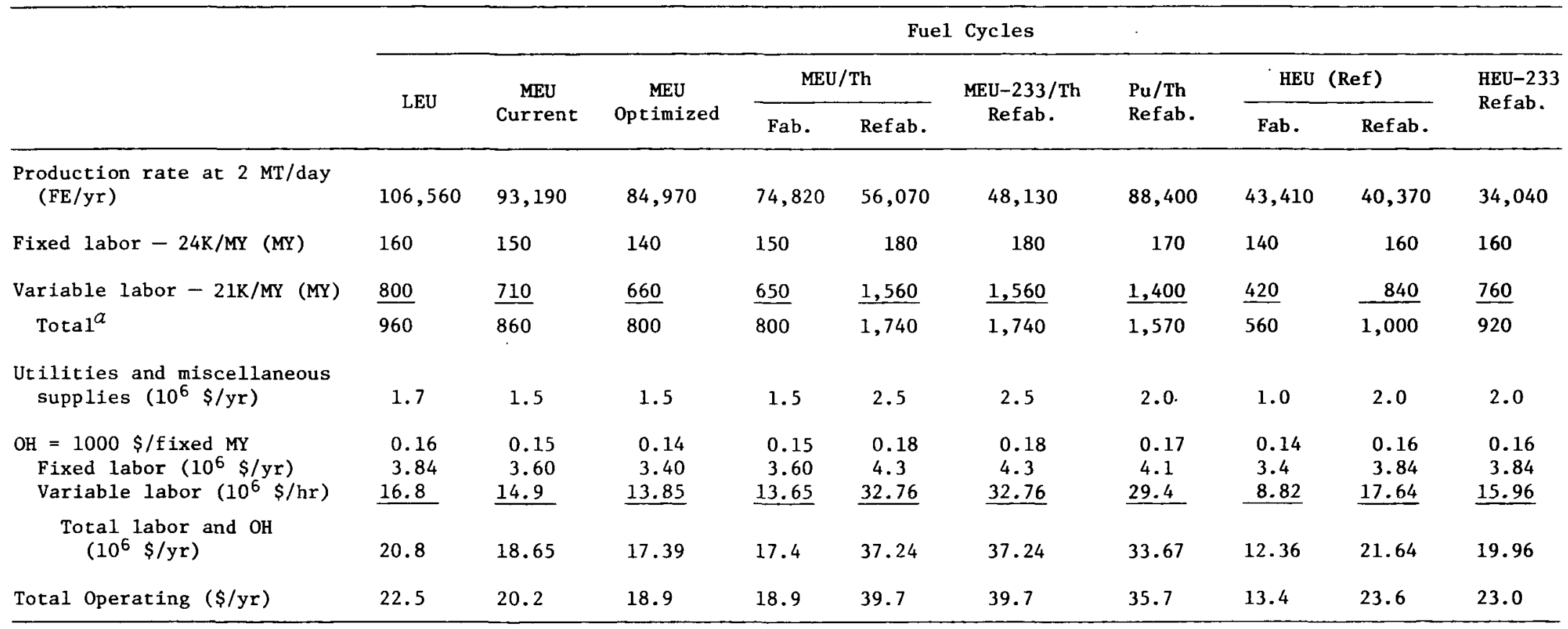

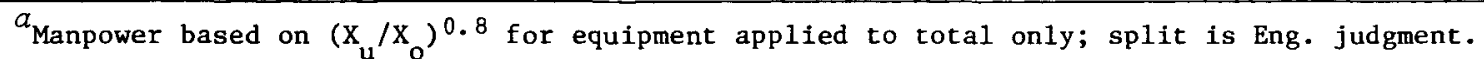


Table B.3. July 1978 HTGR Hardware and Materials Cost Increment Estimates for HTGR Fuels (2 MT/day HM plant)

\begin{tabular}{|c|c|c|c|c|c|c|c|c|c|c|}
\hline & \multicolumn{10}{|c|}{ Fuel Cycles } \\
\hline & \multirow{2}{*}{ LEU } & \multirow{2}{*}{$\begin{array}{l}\text { MEU } \\
\text { Current }\end{array}$} & \multirow{2}{*}{$\begin{array}{l}\text { MEU } \\
\text { Optimized }\end{array}$} & \multicolumn{2}{|c|}{$\mathrm{MEU} / \mathrm{Th}$} & \multirow{2}{*}{$\begin{array}{l}\text { MEU-233/Th } \\
\text { Refab. }\end{array}$} & \multirow{2}{*}{$\begin{array}{l}\mathrm{Pu} / \mathrm{Th} \\
\text { Refab. }\end{array}$} & \multicolumn{2}{|c|}{ HEU (Ref) } & \multirow{2}{*}{$\begin{array}{l}\text { HEU-233 } \\
\text { Refab. }\end{array}$} \\
\hline & & & & Fab. & Refab. & & & Fab. & Refab. & \\
\hline $\mathrm{U}, \mathrm{Pu}, \quad(\mathrm{kg} / \mathrm{FE})$ & 4.88 & 3.09 & 2.62 & 1.93 & 3.55 & 3.99 & 0.84 & 0.74 & $0.65 / 1.24$ & 0.6 \\
\hline Th, $(\mathrm{kg} / \mathrm{FE})$ & & 2.49 & 3.50 & 5.02 & 5.02 & 7.14 & 4.59 & 11.24 & 11.24 & 13.6 \\
\hline $\begin{array}{l}\mathrm{ThO}_{2} \text { (processing and QA) } \\
\quad(40 \$ / \mathrm{kg})\end{array}$ & 0 & 100 & 140 & 200 & 200 & 285 & 185 & 450 & 450 & 540 \\
\hline Uranium penalty & & & & 50 & 50 & & & & & \\
\hline Shim $(17 \$ / k g)$ & 190 & 170 & 170 & 170 & 170 & 170 & 170 & 170 & 170 & 170 \\
\hline Poison waters $(60 \$ / F E)$ & 60 & 60 & 60 & 60 & 60 & 60 & 60 & 60 & 60 & 60 \\
\hline Matrix (2) & 25 & 25 & 25 & 25 & 25 & 25 & 25 & 25 & 25 & 25 \\
\hline Block and plug (1200/FE) & 1,200 & 1,200 & 1,200 & 1,200 & 1,200 & 1,200 & 1,200 & 1,200 & 1,200 & 1,200 \\
\hline $\begin{array}{l}\text { Expendables } \\
\text { R }(308 \$ / F E) \\
F(250 \$ / F E)\end{array}$ & 250 & 250 & 250 & 250 & $\begin{array}{r}308 \\
\end{array}$ & $\begin{array}{r}308 \\
\end{array}$ & $\begin{array}{r}308 \\
\end{array}$ & 250 & $\begin{array}{r}308 \\
\end{array}$ & $\begin{array}{r}308 \\
\end{array}$ \\
\hline Totals $(\$ / F E)$ & 1,725 & 1,805 & 1,845 & 1,955 & 2,013 & 2,048 & 1.948 & 2,155 & 2,213 & 2,303 \\
\hline $\mathrm{kg} \mathrm{HM} / \mathrm{FE}$ & 4.88 & 5.58 & 6.12 & 6.95 & 8.57 & 11.13 & 5.43 & 11.98 & 11.89 & 14.1 \\
\hline $\mathrm{C} / \mathrm{HM}$ & 450 & 385 & 348 & 295 & 240 & 195 & 375 & 169 & $110 / 162$ & 143 \\
\hline Material cost $(\$ / \mathrm{kg} H M)$ & 353.5 & 323.5 & 301.5 & 281.3 & 234.9 & 184.0 & 358.7 & 189.9 & 186.1 & 163 \\
\hline Annual Materials $\left(10^{6} \$ / y r\right)$ & 183.8 & 168.2 & 156.8 & 146.3 & 112.7 & 88.3 & 172.2 & 93.5 & 89.3 & 78.4 \\
\hline
\end{tabular}


ORNL/TM-6640

Distribution

Category UC-80

INTERNAL DISTRIBUTION

1-2. Central Research

3. Document Reference Section

4-5. Laboratory Records Department

6. Laboratory Records, ORNL R.C.

7. ORNL Patent Section

8. T. D. Anderson

9. W. J. Armento

10. D. E. Bartine

11. R. L. Beatty

12. J. O. Blomeke

13. E. S. Bomar

14. H. I. Bowers

15. T. J. Burns

16. J. A. Carpenter, Jr.

17. A. J. Caputo

18. W. L. Carter

19. J. C. Cleveland

20. J. A. Conlin, Jr.

21. A. G. Croff

22. J. G. Delene

23. R. G. Donnelly

24. W. P. Eatherly

25. E. H. Gift

26. R. W. Glass

27. F. E. Harrington

28. M. R. Hayns

29. R. E. Helms

30-32. M. R. Hill

33. F. J. Homan

34. C. R. Hudson

35-44. R. R. Judkins

45-47. P. R. Kasten

48. M. A. Kuliasha
49. W. J. Lackey

50. R. E. Leuze

51. M. H. Lloyd

52. R. S. Lowrie

53. J. E. Mack

54. M. M. Martin

55. S. R. McNeany

56. R. E. Norman

57. K. J. Notz

58-67. A. R. Olsen

68. R. T. Primm

69. H. E. Reesor

70. J.P. Renier

71. T. F. Scanlan

72. J. E. Selle

73. G. R. Smolen

74. I. Spiewak

75. D. P. Stinton

76. V. J. Tennery

77. S. M. Tiegs

78. J. E. Vath

79. D. R. Vandy

80. H. J. Wallace

81. G. C. Wei

82. D. F. Williams

83. B. A. Worley

84. R. W. Balluffi (Consultant)

85. A. L. Bement, Jr. (Consultant)

86. W. R. Hibbard, Jr. (Consultant)

87. E. H. Kottcamp, Jr. (Consultant)

88. M. J. Mayfield (Consultant)

89. J. T. Stringer (Consultant)

EXTERNAL DISTRIBUTION

90-92. Hanford Engineering Development Laboratory, P.O. Box 1970, Richland, WA 99352

M. C. J. Carlson

J. P. Keenan

R. P. Omberg

93. Pacific Northwest Laboratory, P.O. Box 999, Richland, WA 99352

S. Goldsmith

94-96. DOE Division of Nuclear Power Development, Washington, DC 20545
A. J. Pressesky
W. W. Ballard
G. A. Newby 
97-98. DOE Division of Plans and Analysis, Washingtor, DC 20545

S. T. Brewer

M. W. Koehlinger

99-102. DOE Nuclear Alternative Systems Assessment Division, Washington, DC 20545
E. J. Hanrahan
C. Sege
D. E. Mathes
S. Strauch

103-104. DOE Office of INFCE and International Nuclear Affairs, Washington, DC 20545

\section{S. Rosen \\ C. Weber}

105. DOE Office of Nuclear Energy Programs, Washington, DC 20545

R. L. Ferguson, Director

106. DOE San Francisco Operations Office, 1333 Broadway, Wells Fargo Building, Oakland, CA 94612

Manager

107-108. DOE Oak Ridge Operations Office, P.O. Box E, Oak Ridge, TN 37830

Assistant Manager, Energy Research and Development

S. W. Ahrends

109-245. DOE Technical Information Center, P.O. Box 62, Oak Ridge, TN 37830

For distribution as shown in TID-4500 Distribution Category,

UC-80 (General Reactor Technology) 